\title{
Ceramic Mineral Waste-Forms for Nuclear Waste Immobilization
}

\author{
Albina I. Orlova ${ }^{1}$ and Michael I. Ojovan ${ }^{2,3, *}$ \\ 1 Lobachevsky State University of Nizhny Novgorod, 23 Gagarina av., \\ 603950 Nizhny Novgorod, Russian Federation \\ 2 Department of Radiochemistry, Lomonosov Moscow State University, Moscow 119991, Russia \\ 3 Imperial College London, South Kensington Campus, Exhibition Road, London SW7 2AZ, UK \\ * Correspondence: m.ojovan@imperial.ac.uk
}

Received: 31 May 2019; Accepted: 12 August 2019; Published: 19 August 2019

check for updates

\begin{abstract}
Crystalline ceramics are intensively investigated as effective materials in various nuclear energy applications, such as inert matrix and accident tolerant fuels and nuclear waste immobilization. This paper presents an analysis of the current status of work in this field of material sciences. We have considered inorganic materials characterized by different structures, including simple oxides with fluorite structure, complex oxides (pyrochlore, murataite, zirconolite, perovskite, hollandite, garnet, crichtonite, freudenbergite, and P-pollucite), simple silicates (zircon/thorite/coffinite, titanite (sphen), britholite), framework silicates (zeolite, pollucite, nepheline /leucite, sodalite, cancrinite, micas structures), phosphates (monazite, xenotime, apatite, kosnarite (NZP), langbeinite, thorium phosphate diphosphate, struvite, meta-ankoleite), and aluminates with a magnetoplumbite structure. These materials can contain in their composition various cations in different combinations and ratios: $\mathrm{Li}-\mathrm{Cs}, \mathrm{Tl}, \mathrm{Ag}, \mathrm{Be}-\mathrm{Ba}, \mathrm{Pb}, \mathrm{Mn}, \mathrm{Co}, \mathrm{Ni}, \mathrm{Cu}, \mathrm{Cd}, \mathrm{B}, \mathrm{Al}, \mathrm{Fe}, \mathrm{Ga}, \mathrm{Sc}, \mathrm{Cr}, \mathrm{V}, \mathrm{Sb}, \mathrm{Nb}, \mathrm{Ta}, \mathrm{La}, \mathrm{Ce}$, rare-earth elements (REEs), $\mathrm{Si}, \mathrm{Ti}, \mathrm{Zr}, \mathrm{Hf}, \mathrm{Sn}, \mathrm{Bi}, \mathrm{Nb}, \mathrm{Th}, \mathrm{U}, \mathrm{Np}, \mathrm{Pu}, \mathrm{Am}$ and $\mathrm{Cm}$. They can be prepared in the form of powders, including nano-powders, as well as in form of monolith (bulk) ceramics. To produce ceramics, cold pressing and sintering (frittage), hot pressing, hot isostatic pressing and spark plasma sintering (SPS) can be used. The SPS method is now considered as one of most promising in applications with actual radioactive substances, enabling a densification of up to $98-99.9 \%$ to be achieved in a few minutes. Characteristics of the structures obtained (e.g., syngony, unit cell parameters, drawings) are described based upon an analysis of 462 publications.
\end{abstract}

Keywords: crystalline ceramics; nuclear waste; immobilization; sintering; spark plasma sintering

\section{Introduction}

Crystalline ceramics, aiming to immobilize high-level radioactive waste (HLW), are important for the current stage of development of modern nuclear technology in the world.

The crystal-chemical principle is used to design multicomponent ceramics with needed structures. The approach to designing mineral-like crystalline materials is based upon the structural features of materials and isomorphism concept. The choice of the structural forms of compounds for discussion here was based upon the following criteria:

(1) The ability of the structure to include various cations in different combinations and ratios.

(2) Known high stability of structure to the action of the destructive factors of the environment during their prolonged exposure ("mineral-like" compounds preferred while "the nature suggests") such as high temperatures, thermal "stresses", radiation levels, the corrosive action of water and other chemical solutions. Criteria for the resistance of materials to such effects are justified by 
the features of the crystal structure of materials including small interatomic distances, and the possibility of their controlled variation in the desired direction when cations and/or anions of given sizes are included in the crystallographic positions. Most of the crystalline matrices discussed in the present work meet these criteria in full or in part. Herewith the classification criteria for crystalline ceramics were based on considering first simple and then more complex structures, e.g., starting with oxides (from simple oxides to complex oxides) and moving to salt compositions (from simple salt to complex ones).

The concept of immobilizing the radioactive elements of nuclear waste in an assemblage of mineral phases was originally introduced by Hatch [1] at Brookhaven National Laboratory in 1953. The feasibility of making a ceramic of natural, mineralogically-stable phases was demonstrated by McCarthy [2,3] and Roy [4] at the Pennsylvania State University between 1973 and 1976. Since that time, a number of other mineralogic-ceramic assemblages have been developed [5]. Among these are the Sandia titanate-based ceramic [6], the Australian ceramic "SYNROC" [7-10], the silicate-phosphate supercalcine ceramics [11], the alumina-based tailored ceramics [12,13] and the Pu pyrochlores [14,15]. The structural types of monazite, kosnarite (NZP), langbeinite and other ones were considered as matrices for the incorporation of simulated wastes containing f-elements and that also contain uni-, bi-, and trivalent elements involved in radiochemical processes [16-27]. Cold pressing and sintering, as well as hot isostatic pressing often result in ceramics containing an intergranular glassy phase with radionuclides preferentially migrating to the glassy phase [28-36]. The radionuclides that are incorporated in the intergranular glassy phase(s) will then have leaching rates at about the same order as those from a glassy waste-form.

Crystalline waste-forms synthesized at moderate temperatures such as within 700 to $750{ }^{\circ} \mathrm{C}$ have not been investigated as intensely as those formed at high temperatures [11], although crystalline waste-forms made from clay have been studied almost continuously since the 1953 work of Hatch $[1,11]$. Supercalcine ceramics synthesized at high temperatures often contained sodalite-cancrinite mineral assemblages. Roy [37] proposed in 1981 a low solubility phase assemblage as a waste-form [37] using a low temperature hydrothermal process. The assemblage consisted of micas, apatite, pollucite, sodalite-cancrinite and nepheline, many of which could be produced using various clay minerals such as kaolin, bentonite and illite mixed with radioactive waste. However there were no continuous commercial technologies available at that time that could process the waste/clay mixtures in a hydrothermal environment, and clay-based crystalline waste-forms were not pursued. The situation changed in 1999 when Studsvik had built in Erwin a commercial facility to continuously process radioactive wastes by pyrolysis at moderate temperatures in a hydrothermal steam environment [38,39]. This facility utilizes Fluidized Bed Steam Reforming (FBSR) technology to pyrolyze ${ }^{137}$ Cs- and ${ }^{60} \mathrm{Co}$-contaning spent organic ion exchange resins produced by commercial nuclear facilities. FBSR technology can also process a wide variety of solid and liquid radioactive wastes, including spent organic ion exchange resins, charcoal, graphite, sludge, oils, solvents and cleaning solutions with contaminations up to radiation levels reaching $4 \mathrm{~Sv} / \mathrm{h}(400 \mathrm{R} / \mathrm{hr})$. The waste organics are destroyed, creating steam and $\mathrm{CO}_{2}$. The clay serves in the FBSR process as a mineralizing agent, and feldspathoid minerals (sodalite, nosean and nepheline) are formed by the nanoscale reaction of waste components with clay. The phases formed act as hosts for waste contaminants such as $\mathrm{Cl}, \mathrm{I}, \mathrm{F},{ }^{99} \mathrm{Tc}$ from $\mathrm{SO}_{4}$ alkali ( $\mathrm{Na}, \mathrm{K}, \mathrm{Cs})$ bearing wastes [40-44]. The mineralization occurs at moderate temperatures used within the range when most clays become amorphous at the nanoscale level, e.g., kaolin, bentonite (montmorillonite), and illite. The octahedral $\mathrm{Al}^{3+}$ cation in the clay structure is destabilized, and clays become amorphous as confirmed by X-ray diffraction (XRD) analysis, losing their hydroxyl (OH-) groups. The alkalis from waste act as activators of unstable $\mathrm{Al}^{3+}$ cations, and form new mineral phases catalyzing the mineralization. In the absence of steam many of these mineral phases can only be formed if temperatures are above $1200^{\circ} \mathrm{C}$.

Many of the compounds under consideration have structures similar to those of natural minerals (the so-called mineral-like compounds). Others of the discussed ones are not structural analogs of 
any known minerals (that its, of what is known today, as there are examples of compounds being developed for the radioactive waste immobilization that were obtained synthetically, and many years later a mineral was discovered, whose structural analog they became. For example, the mineral kosnarite $\mathrm{KrZr}_{2}\left(\mathrm{PO}_{4}\right)_{3}$ was discovered in 1991, and then kosnarite-like compounds (for example, NZP and NASICON) were synthesized and investigated many years before the discovery of this mineral).

Ceramic waste-forms can range from single phase, i.e., $\mathrm{UO}_{2}$ and single phase solid solutions, i.e., $(\mathrm{U}, \mathrm{Th}, \mathrm{Pu}) \mathrm{O}_{2}$, to multiphase ceramics formulated in a such way that each waste radionuclide can substitute on a given host lattice in the various phases used.

\section{Theoretical Aspects of Substitution}

The crystal-chemical substitutions in crystalline waste-forms must be electrically balanced $[45,46]$ which is important when relying on the long range order (LRO) of crystals accounting for the size and coordination of the crystallographic site, which will act as host to a given radionuclide, or its decay product upon transmutation (see [15] for natural analogs). Moreover, if a monovalent cation transmutes to a divalent one, the substitutions must be coupled to retain the electrical balance of the host phase without destroying the integrity of the phase. It means that the lattice site must be of suitable size and have a bond coordination able to accept the cation resulting from transmutation. The bond system of a crystalline ceramic can only maintain its charge balance if:

(1) Sufficient lattice vacancies exist in the structure or,

(2) A variable valence cation such as $\mathrm{Fe}$ or $\mathrm{Ti}$ is present in a neighboring lattice site balancing the charge.

Both above ways assume that the variable valence cations do not change lattice sites, and that the charge balancing cations are in the nearby lattice sites of the same host phase. The lattice site must be of close size flexible enough to accommodate the transmuting cation. Better flexibility is characteristic to host phases with lattice sites having irregular coordination or are distorted, as shown in some examples below. The flexibility (solubility) of waste-form mineral phase(s) as hosts for a different valence substituted cation can be analyzed by performing coupled substitutions. When the number of cations changes during the substitution, a vacancy is either created or consumed, however the substitution must maintain electrical neutrality. These types of substitution are characteristic for polymorphic changes such as [47], where $\square$ denotes a vacancy:

$$
\square+\mathrm{Ba}^{2+} \rightarrow 2 \mathrm{~K}^{+} \text {, or } \mathrm{q}+\mathrm{Ca}^{2+} \rightarrow 2 \mathrm{Na}^{+} \text {, or } \square+\mathrm{Na}^{+}+2 \mathrm{Ca}^{2+} \rightarrow 3 \mathrm{Na}^{+}+\mathrm{Ca}^{2+}
$$

In these coupled substitutions it is implicit that the exchanging cations occupy the same lattice sites, have the same coordination, and thus the crystallographic symmetry is maintained. These substitutions are typically written using Roman numerals that designate the number of oxygen atoms that coordinate around a given cation, e.g., ${ }^{\mathrm{VIII}} \mathrm{Ca}$ designates the octahedral VIII-fold coordination for the $\mathrm{Ca}^{2+}$ lattice site in oxyapatites:

$$
\underbrace{3 \mathrm{Ca}^{2+}}_{\text {host phase }} \rightarrow \underbrace{2 \mathrm{Nd}^{3+}+\square}_{\text {substituted phase }}
$$

Calcium-neodymium-coupled substitutions were proven successful in the apatite $\left(\mathrm{Ca}_{6}\left[\mathrm{SiO}_{4}\right]_{3}\right)$ structure, resulting in a completely substituted $\mathrm{Nd}_{4} \square_{2}\left[\mathrm{SiO}_{4}\right]_{3}$, where $2 / 3$ of the lattice sites have $\mathrm{Nd}^{3+}$ and $1 / 3$ are vacant [45-47]. $\mathrm{Ca}^{2+}$ is normally in VIII-fold coordination in the apatite and has a $1.12 \AA$ atomic radius [47-50]. The $\mathrm{Nd}^{3+}$ cation in VIII-fold coordination also has an atomic radius of $1.11 \AA$ [50], which is very close to the $\mathrm{Ca}^{2+}$ atomic radius in VIII-fold coordination. It has been shown that the rare earth elements from $\mathrm{La}^{3+}$ through $\mathrm{Lu}^{3+}$ can substitute for $\mathrm{Ca}^{2+}$ and form oxyapatites, 
$\mathrm{RE}_{4.67} \square_{0.33}\left[\mathrm{SiO}_{4}\right]_{3} \mathrm{O}$ [51]. It was also shown [3] that even more complex but coupled substitutions were possible in the oxyapatite structure, such as:

$$
\underbrace{6^{\text {VIII }} \mathrm{Ca}^{2+}}_{\text {host phase }} \rightarrow \underbrace{1.7^{\text {VIIII }} \mathrm{Nd}^{3+}+1.7^{\text {VIIII }} \mathrm{Cs}^{+}+0.86^{\text {VIIII }} \mathrm{Ce}^{4+}+0.86^{\text {VIIII }} \mathrm{Sr}^{2+}+0.88 \square}_{\text {substituted phase }}
$$

where the atomic radius, $r$, of $\mathrm{Cs}^{+}$in VIII-fold coordination is $1.74 \AA \mathrm{Ce}^{4+}$ in VIII-fold coordination is $0.97 \AA$, and $\mathrm{Sr}^{2+}$ in VIII-fold coordination is $1.26 \AA$. In this case small radii cations e.g., $\mathrm{Ce}^{4+}$ are mixed with larger radii cations such as $\mathrm{Cs}^{+}$, so that individual lattice sites can distort without perturbing the entire crystal structure of the host mineral. It should be noted that the exchanging cations are always in the same lattice site of the same host phase $[3,45,46,51]$.

The substitutions such as those given above for the oxyapatites were also demonstrated to be possible in many other Ca-bearing mineral phases such as larnite $\left(\mathrm{Ca}_{2} \mathrm{SiO}_{4}\right.$ or $\left.b-\mathrm{C}_{2} \mathrm{~S}\right)$, alite (calcium trisilicate or $\mathrm{Ca}_{3} \mathrm{SiO}_{5}$ or $\left.\mathrm{C}_{3} \mathrm{~S}\right), \mathrm{C}_{3} \mathrm{~A}\left(\mathrm{Ca}_{3} \mathrm{Al}_{2} \mathrm{O}_{6}\right)$ and $\mathrm{C}_{4} \mathrm{AF}\left(\mathrm{Ca}_{4} \mathrm{Al}_{2} \mathrm{Fe}_{2} \mathrm{O}_{10}\right)$, characteristic for cements $[45,46]$. This allowed Jantzen, et. al. $[52,53]$ to make substitutions for $\mathrm{Ca}^{2+}$ in each phase (up to $\sim 15 \mathrm{~mole} \%$ ) and prove possible the following additional substitutions:

$$
\begin{aligned}
& \underbrace{\mathrm{Ca}^{2+}+\square}_{\text {host phase }} \rightarrow \underbrace{2 \mathrm{Cs}^{+}}_{\text {substituted phase }} \\
& \underbrace{2 \mathrm{Ca}^{2+}+\square}_{\text {host phase }} \rightarrow \underbrace{\mathrm{Cs}^{+}+\mathrm{Sr}_{0.5}^{2+}+\mathrm{Nd}_{0.17}^{3+}+\mathrm{Ce}_{0.25}^{4+}+0.08 \square}_{\text {substituted phase }} \\
& \underbrace{1.5 \mathrm{Ca}^{2+}+\mathrm{Sr}^{4+}}_{\text {host phase }} \rightarrow \underbrace{\mathrm{Sr}^{2+}+\mathrm{Mo}^{5+}+0.5 \square}_{\text {substituted phase }} \\
& \underbrace{4 \mathrm{Ca}^{2+}+\mathrm{Fe}^{3+}+\mathrm{Al}^{3+}}_{\text {host phase }} \rightarrow \underbrace{0.66 \mathrm{Nd}^{3+}+\mathrm{Zr}^{4+}+\mathrm{Mo}^{4+}+\mathrm{Sr}^{2+}+\mathrm{Ba}^{2+}+1.33 \square}_{\text {substituted phase }} \\
& \underbrace{\underbrace{4^{I X} \mathrm{Ca}^{2+}}_{r \sim 1.18 \AA}+\underbrace{2^{V I} \mathrm{Fe}^{3+}}_{r=0.65 \AA}}_{\text {host phase }} \rightarrow \underbrace{\underbrace{2.66^{I X} \mathrm{Nd}^{3+}}_{r=1.16 \AA}+\underbrace{0.38^{V I} \mathrm{Ce}^{4+}}_{r=0.87 \AA}+\underbrace{0.56^{V I} \mathrm{Zr}^{4+}}_{r=0.72 \AA}+\underbrace{0.75^{V I} \mathrm{Fe}^{3+}}_{r=0.65 \AA}+1.65 \square}_{\text {substituted phase }}
\end{aligned}
$$

It should be noted that the number of lattice sites have to be equivalent on the left-hand side and right hand site of the above equations.

These types of crystal-chemical substitutions have been studied in several waste-forms including SYNROC (SYNthetic ROCk) titanate phases containing zirconolite $\left(\mathrm{CaZrTi}_{2} \mathrm{O}_{7}\right)$, perovskite $\left(\mathrm{CaTiO}_{3}\right)$, and hollandites (nominally $\mathrm{Ba}\left(\mathrm{Al}, \mathrm{Ti}_{2} \mathrm{Ti}_{6} \mathrm{O}_{16}\right)$ [54], and in high alumina-tailored ceramic phases such as magnetoplumbites. Notable that magnetoplumbites were also found as a minor component of SYNROC, which immobilizes waste with high contents of Al [55].

Hollandite is the $\mathrm{Cs}^{+}$host phase in the SYNROC phase assemblages. Its structure can be written as $\mathrm{Ba}_{\mathrm{x}} \mathrm{Cs}_{\mathrm{y}}(\mathrm{Al}, \mathrm{Fe})_{2 \mathrm{x}+\mathrm{y}} \mathrm{Ti}_{8-2 x y} \mathrm{O}_{16}$ where $\mathrm{x}+\mathrm{y}$ must be $<2$ [56]. It has two types of octahedral sites, one of which accommodates trivalent cations like $\mathrm{Al}^{3+}, \mathrm{Ti}^{3+}$ and $\mathrm{Fe}^{3+}$, while the other accommodates $\mathrm{Ti}^{4+}$. The $\mathrm{Cs}^{+}$is accommodated in tunnels that normally accommodate the $\mathrm{Ba}^{2+}$ cation, and Cs-Ba lattice sites are VIII-fold coordinated $[54,56]$. On synthesis the substitution orders and incommensurate 
superstructures result when $\mathrm{Cs}^{+}$substitutes for $\mathrm{Ba}^{2+}[55]$. Cs has been experimentally substituted for $\mathrm{Ba}$ when $\mathrm{Fe}^{3+}$ is substituted for $\mathrm{Ti}^{4+}$ in the VI-fold sites of hollandite. The species

$$
\underbrace{{ }^{V I I I} \mathrm{Cs}_{0.28}^{+}{ }^{V I I} \mathrm{Ba}_{1.00}^{2+}{ }^{V I} \mathrm{Al}_{1.46}^{3+}{ }^{V I} \mathrm{Fe}_{0.82}^{3+}{ }_{\text {site }}^{V I} \mathrm{Ti}_{\text {C site }}^{4+}{ }_{52}^{4+} \mathrm{O}_{16}}_{\text {A site }}
$$

has been synthesized by the sintering (frittage) of precursors in air at $1320^{\circ} \mathrm{C}$ [56]. Ba-Al hollandite $\left(\mathrm{Ba}_{1.16} \mathrm{Al}_{2.32} \mathrm{Ti}_{5.68} \mathrm{O}_{16}\right)$ was irradiated with $1-2.5 \mathrm{MeV}$ electrons and $\beta$-irradiated up to summary doses of $4 \times 10^{8}$ to $7 \times 10^{9} \mathrm{~Gy}$, after which it was found to contain $\mathrm{Ti}^{3+}$ centers and $\mathrm{O}_{2}-$ superoxide ions that confirmed the mechanism of charge balance during transmutation [56]. Theoretically, the limiting value of Cs in hollandite is $\mathrm{y}=0.81$, which corresponds to a $9.54 \mathrm{wt} \%$ waste loading of $\mathrm{Cs}_{2} \mathrm{O}$ [57].

\section{Synthesis of Ceramic Waste-Forms}

Research and development of ceramic materials based upon compounds on the base of the oxides and salt compositions were carried out for the immobilization of high-level wastes and the transmutation of minor actinides. Structures of such materials provide the incorporation of various cations and anions, either individually, or in various combinations and ratios. Structural forms in which can be implemented a wide isomorphism of cations and anions (including in different crystallographic positions) deserve special attention.

Among such structures the type $\mathrm{NaZr}_{2}\left(\mathrm{PO}_{4}\right)_{3}$ (NZP) (analog-Mineral kosnarite) is regarded. NZP solid solutions may include more than half of the elements of Periodic Table of Elements in various combinations and ratios. The SYNROC developer calls them "near-universal solvent" [23], wherein this form of the consolidation of waste components is mono-phase in contrast to the multiphase SYNROC.

Ceramic materials are synthesized using the following methods: Pressing and sintering (frittage), hot isostatic or hot uniaxial pressing and other variants. Method Spark Plasma Sintering is the perspective for this aim. It provides a formation of virtually no porous ceramics having a relative density close to $99-100 \%$ for short time intervals (from 3 to $15 \mathrm{~min}$ ). Reducing the porosity reduces the free surface, and therefore reduces the reaction surface and reactivity in heterogeneous systems with the participation of such materials. This in turn increases the heat, radiation and chemical stability of the ceramic.

Ceramic forms characteristics are presented here with their structures.

\section{Crystalline Ceramic Phase:}

\subsection{Simple Oxides}

1. Silica, $\mathrm{SiO}_{2}$ [58-75], Figure 1.

Silicon dioxide, commonly known as silica (and/or quartz), is a prevalent element in the Earth's crust, a mineral of most igneous and metamorphic rocks. The formula " $\mathrm{SiO}_{2}$ " is commonly known as silicon dioxide. Silicon dioxide has a wide range of purposes, the main one being glass manufact-uring. In nature, silicon dioxide is commonly found as sand and quartz. Silica has polymorphism. It is stable under normal conditions of polymorphic modification- $\alpha$-quartz (low temperature). Accordingly, $\beta$-quartz is called a high-temperature modification. Silica ( $\alpha$-quartz) possesses the rhombohedral structure, sp. gr. R3. Various elements with various oxidation states may attend in quartz: $\mathrm{Li}, \mathrm{Na}, \mathrm{K}$. $\mathrm{Mg}, \mathrm{Ca}, \mathrm{Mn}, \mathrm{Cu}, \mathrm{Ni}, \mathrm{Pb}$ B, $\mathrm{Al}, \mathrm{Fe}, \mathrm{Cr}, \mathrm{Ti}, \mathrm{Zr}$ and Te. Materials based on silicon oxide $\mathrm{SiO}_{2}$, Silica (quartz) were prepared in ceramic form by using methods: Hot isostatic pressing, laser sintering, cold pressing and sintering at $1500^{\circ} \mathrm{C}$, cold pressing and ultra-low temperature sintering at $\mathrm{T}=554-600^{\circ} \mathrm{C}(30 \mathrm{~min})$ and Spark Plasma Sintering.

Materials on the base of Silica can serve as a matrix for the immobilization of radioactive Iodine I-129 (half-life $\mathrm{T}_{1 / 2}=15.7 \times 10^{3}$ years). 

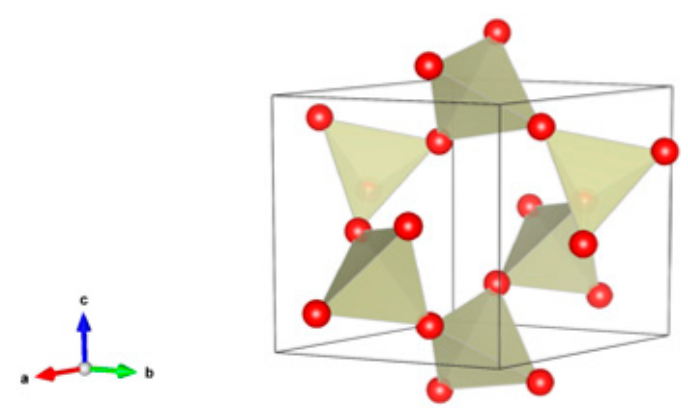

Figure 1. Silica, $\mathrm{SiO}_{2} . \alpha$-quartz (low temperature modification), structure rhombohedra, Sp. gr. R3. $\beta$-quartz (high-temperature modification, it forms from $\alpha$-quartz at $846 \mathrm{~K}$, stable up to $1140 \mathrm{~K}$ ). Structure hexagonal, Sp. gr. $\mathrm{P}_{2} 22$. Cations can be $\mathrm{Li}, \mathrm{Na}, \mathrm{K} . \mathrm{Mg}, \mathrm{Ca}, \mathrm{Mn}, \mathrm{Cu}, \mathrm{Ni}, \mathrm{Pb} \mathrm{B}, \mathrm{Al}, \mathrm{Fe}, \mathrm{Cr}, \mathrm{Ti}, \mathrm{Zr}$ and Te.

2. Oxides Fluorite, $\mathrm{XO}_{2}$ [76-93], Figure 2 .

$\mathrm{ZrO}_{2}, \mathrm{UO}_{2}, \mathrm{ThO}_{2}, \mathrm{HfO}_{2}, \mathrm{PuO}_{2}, \alpha-\mathrm{U}_{2} \mathrm{O}_{3}$ and $\mathrm{Np}_{2} \mathrm{O}_{3}$ have the simple fluorite cubic structure, sp. gr. Fm $3 \mathrm{~m}$. Fluorite has physical properties that allow it to be used for a wide variety of chemical, metallurgical and ceramic processes. The waste ceramics with high zirconia and alumina contents, and $\mathrm{Y}_{2} \mathrm{O}_{3}$-stabilized zirconia with fluorite structure, are the main host phases for actinide, rare earth elements, as well as Cs, Sr in high-level radioactive waste (HLW). Ceramics were made by HIP, HUP, press and sinter, melting and crystallization and by Spark Plasma Sintering with high relative density (up to $97-99 \%$ ).

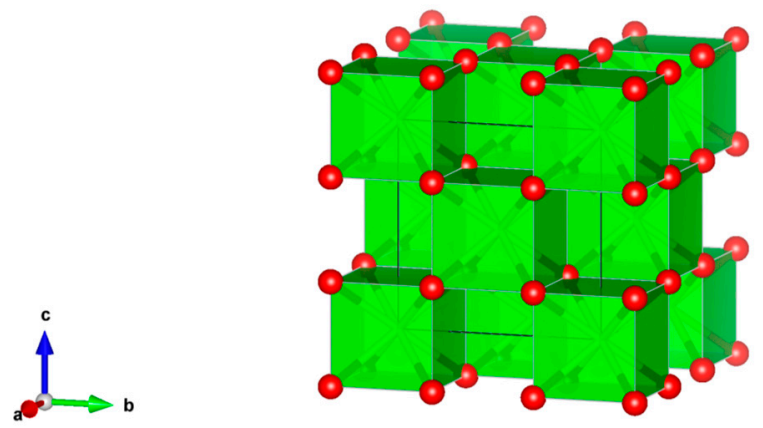

Figure 2. Fluorite, $\mathrm{ZrO}_{2}$. Structure cubic, Sp. gr. Fm3m. Cations can be $\mathrm{Zr}, \mathrm{Hf}, \mathrm{Th}, \mathrm{U}, \mathrm{Np}$ and $\mathrm{Pu}$.

\subsection{Complex Oxides}

3. Pyrochlore [86,94-117], Figure 3.

Many compounds with $\mathrm{A}_{2} \mathrm{~B}_{2} \mathrm{O}_{7}$ stoichiometry adopt the pyrochlore structure. A derivative of the fluorite structure type, $\mathrm{A}_{2} \mathrm{~B}_{2} \mathrm{O}_{7}$, where the A-site contains large cations $(\mathrm{Na}, \mathrm{Ca}, \mathrm{U}, \mathrm{Th}, \mathrm{Y}$ and lanthanides) and the B-site contains smaller, higher valence cations $\left(\mathrm{Nb}, \mathrm{Ta}, \mathrm{Ti}, \mathrm{Zr}\right.$ and $\left.\mathrm{Fe}^{3+}\right)$. Structure: Cubic, Sp. gr. $F d_{3} \mathrm{~m}, \mathrm{z}=8$. Ceramics were prepared by cold pressing and sintering.

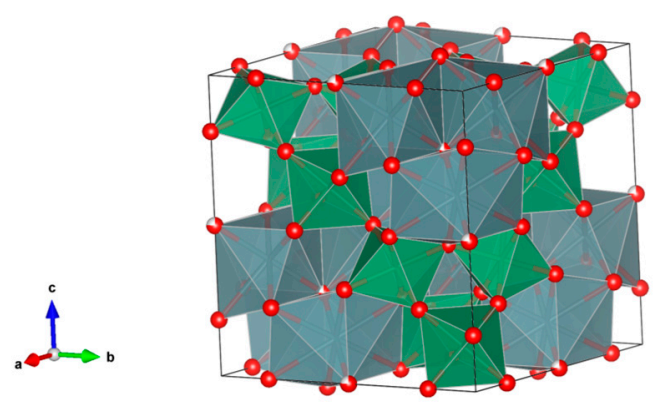

Figure 3. Pyrochlore. $\mathrm{A}_{2} \mathrm{~B}_{2} \mathrm{O}_{7}$. Structure cubic, Sp. gr. Fd3m. A-site-cations can be $\mathrm{Na}, \mathrm{Ca}, \mathrm{Y}$, lanthanides, Th and $\mathrm{U}$, while on the B-site-cations can be $\mathrm{Fe}^{3+}, \mathrm{Ti}, \mathrm{Zr}, \mathrm{Nb}$ and $\mathrm{Ta}$. 
4. Murataite [104,106,108,118-131], Figure 4.

Murataite is a derivative of the isometric fluorite structure $\mathrm{A}_{6} \mathrm{~B}_{12} \mathrm{C}_{5} \mathrm{TX} \mathrm{X}_{40-\mathrm{x}}$, with multiple units of the fluorite unit cell; hosts $\mathrm{U}, \mathrm{Np}, \mathrm{Pu}, \mathrm{Am}, \mathrm{Cm}$ and REE, including $\mathrm{Gd}$, a neutron absorber. It forms in solid solution with pyrochlore. Structure: Cubic, Sp. gr. $F 4 \frac{3}{3} \mathrm{~m}, \mathrm{z}=4$. Ceramics were prepared by cold pressing and sintering.

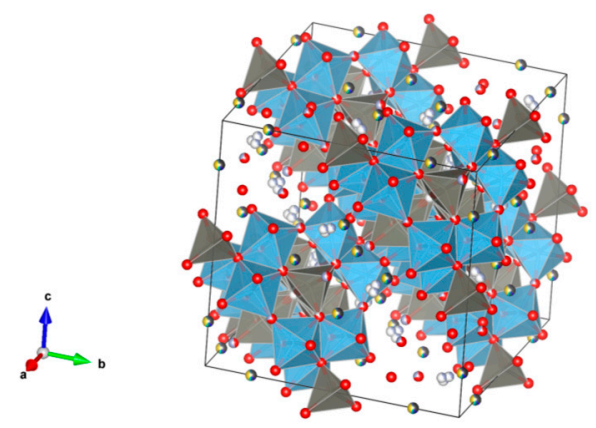

Figure 4. Murataite. $\mathrm{A}_{6} \mathrm{~B}_{12} \mathrm{C}_{5} \mathrm{TX}_{40-\mathrm{x}}$. Structure: Cubic, Sp. gr. F4m. Cations can be U, Np, Pu, Am, $\mathrm{Cm}$ and REE, including $\mathrm{Gd}$ (a neutron absorber).

5. Zirconolite [112,113,132-150], Figure 5.

Monoclinic $\mathrm{CaZrTi}_{2} \mathrm{O}_{7}$, has a fluorite-derived structure closely related to pyrochlore, where $\mathrm{Gd}$, $\mathrm{Hf}, \mathrm{Ce}$, Th, $\mathrm{U}, \mathrm{Pu}$ and $\mathrm{Nb}$ may be accommodated on the $\mathrm{Ca} / \mathrm{Zr}$-sites, as in the case of $\mathrm{Ca}(\mathrm{Zr}, \mathrm{Pu}) \mathrm{Ti}_{2} \mathrm{O}_{7}$. Structure: Trigon., Pr. gr. C2/c. Ceramics were prepared by cold pressing and sintering.

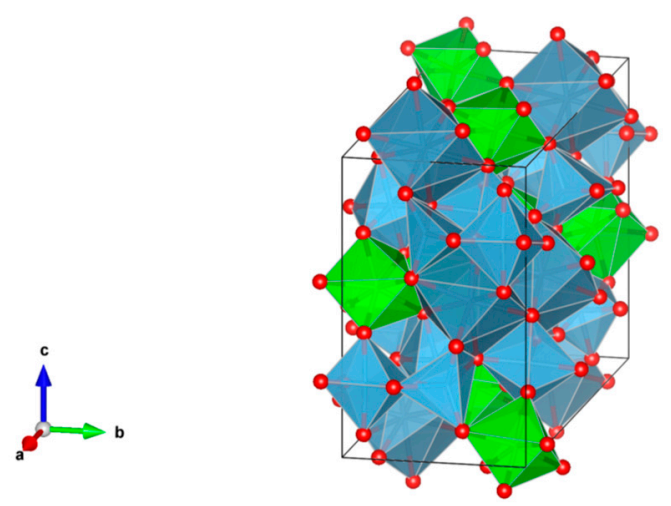

Figure 5. Zirconolite. $\mathrm{CaZrTi}_{2} \mathrm{O}_{7}$, Structure monoclinic, Sp. gr. C2/c. Cations can be Gd, Hf, Ce, Th, U, $\mathrm{Pu}$ and $\mathrm{Nb}$.

\section{Perovskite [110,134,140,151-159], Figure 6.}

$\mathrm{CaTiO}_{3}$ has a wide range of compositions as stable solid-solutions; orthorhombic; consists of a 3-dimensional network of corner-sharing $\mathrm{TiO}_{6}$ octahedra, with $\mathrm{Ca}$ occupying the large void spaces between the octahedra (the corner-sharing octahedra are located on the eight corners of a slightly distorted cube). Plutonium, other actinides and rare-earth elements can occupy the Ca site in the structure, as in $(\mathrm{Ca}, \mathrm{Pu}) \mathrm{TiO}_{3}$. The octahedra can also tilt to accommodate larger cations in the Ca site. Structure: Cubic, sp. gr. Pm3m; rombohedral, Sp. gr. Pnma; may include: Ca, Y, REE, Ti, Zr, U and Pu. Ceramics were prepared by cold pressing and sintering, and by hot pressing enabling densities up to $90-98 \%$ of theoretical. 


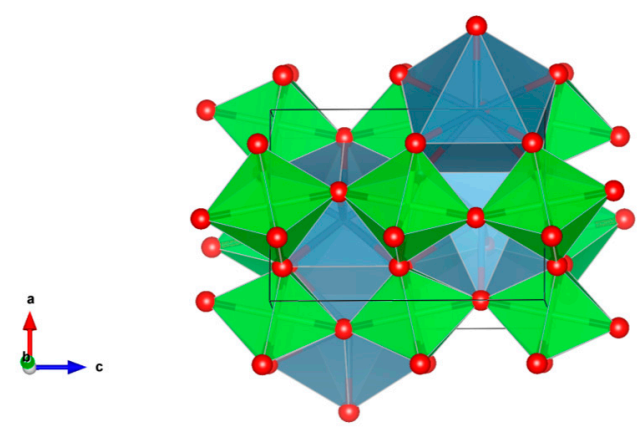

Figure 6. Perovskite. $\mathrm{CaTiO}_{3}$, Structure cubic, Sp. gr. Pm3m. Cations can be Ca, Y, REE, Ti, Zr, U and $\mathrm{Pu}$.

7. Hollandite [160-169], Figure 7.

$\mathrm{Ba}_{1.2}(\mathrm{Al}, \mathrm{Ti})_{8} \mathrm{O}_{16}$ tunnels between $\mathrm{TiO}_{6}$ octahedra to accommodate ${ }^{133} \mathrm{Ba},{ }^{137} \mathrm{Cs}$ and ${ }^{90} \mathrm{Sr}$. Structure: Tetragon, Sp. gr. I4/m, Z = 4 and monocl., Sp. gr. I2/m, $\mathrm{z}=1$; may include: $\mathrm{Na}, \mathrm{K}, \mathrm{Cs}, \mathrm{Mg}, \mathrm{Ca}, \mathrm{Ba}, \mathrm{Al}$, $\mathrm{Fe}, \mathrm{Mn}^{3+}, \mathrm{Si}, \mathrm{Ti}$ and $\mathrm{Mn}^{4+}$. Ceramics were prepared by cold pressing and sintering.

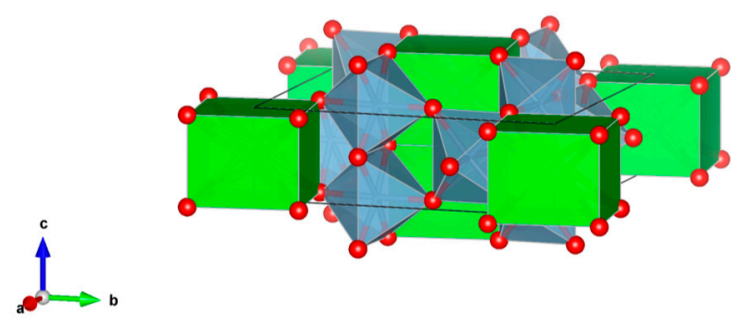

Figure 7. Hollandite. $\mathrm{Ba}_{1.2}(\mathrm{Al}, \mathrm{Ti})_{8} \mathrm{O}_{16}$. Structure tetragon, Sp. gr. I4/m, monocl, Sp. gr. I2/m. Cations can be $\mathrm{Na}, \mathrm{K}, \mathrm{Cs}, \mathrm{Mg}, \mathrm{Ca}, \mathrm{Sr}, \mathrm{Ba}, \mathrm{Al}, \mathrm{Fe}, \mathrm{Mn}^{3+}, \mathrm{Si}$, Ti and $\mathrm{Mn}^{4+}$.

8. Garnet $[87,89,104,105,170-194]$, Figure 8 .

(1) $\quad{ }^{[8]} \mathrm{A}_{3}{ }^{[6]} \mathrm{B}_{2}\left[\mathrm{TiO}_{4}\right]_{3}$, e.g., ${ }^{[8]}(\mathrm{Ca}, \mathrm{Gd} \text {, actinides })^{[6]} \mathrm{Fe}_{2}{ }^{[4]} \mathrm{Fe}_{3} \mathrm{O}_{12}$.

(2) $\quad \mathrm{A}_{3} \mathrm{~B}_{2}\left(\mathrm{XO}_{4}\right)_{3}$; distorted cubic structure; $\mathrm{BO}_{6}$ octahedra and $\mathrm{XO}_{4}$ tetrahedra establish a framework structure alternately sharing corners; $\mathrm{A}$ and $\mathrm{B}$ sites can host actinides, REs, $\mathrm{Y}$, $\mathrm{Mg}, \mathrm{Ca}, \mathrm{Fe}^{2+}, \mathrm{Mn}^{2+}$ and $\mathrm{X}=\mathrm{Cr}^{3+}, \mathrm{Fe}^{3+}, \mathrm{Al}^{3+}, \mathrm{Ga}^{3+}, \mathrm{Si}^{4+}, \mathrm{Ge}^{4+}$ and $\mathrm{V}^{5+}$. Structure: Cubic, Sp. gr. Ia $3 \mathrm{~d}, \mathrm{z}=8$. Ceramics were prepared by cold pressing and sintering and using Spark Plasma Sintering with high relative density up to $98-99 \%$ of theoretical.

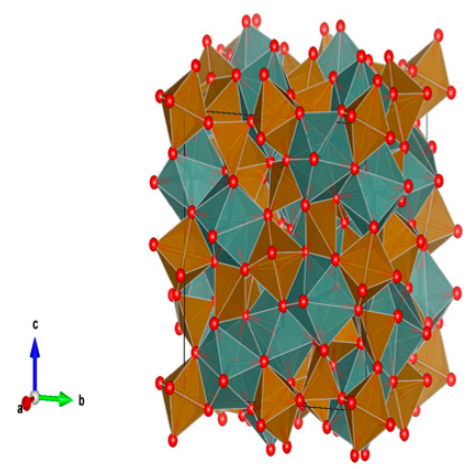

Figure 8. Garnet, $\mathrm{Ca}_{3} \mathrm{Al}_{2} \mathrm{Si}_{3} \mathrm{O}_{12}$. Structure cubic, Sp. gr. Ia3d. Cations can be $\mathrm{Mg}, \mathrm{Ca}, \mathrm{Mn}, \mathrm{Co}, \mathrm{Cd}, \mathrm{Al}$, Sc, Fe, Ga, Y, In, La, REE, Ti, Zr, Ru, Sn, N, P, V and As. 
9. Crichtonite [131,195-202], Figure 9.

$(\mathrm{Sr}, \mathrm{Pb}, \mathrm{La}, \mathrm{Ce}, \mathrm{Y})\left(\mathrm{Ti}_{1} \mathrm{Fe}^{3+}, \mathrm{Mn}, \mathrm{Mg}, \mathrm{Zn}, \mathrm{Cr}, \mathrm{Al}, \mathrm{Zr}, \mathrm{Hf}, \mathrm{U}, \mathrm{V}, \mathrm{Nb}, \mathrm{Sn}, \mathrm{Cu}, \mathrm{Ni}\right)_{21} \mathrm{O}_{38} . \mathrm{Sr}, \mathrm{La}, \mathrm{Ce}, \mathrm{Y}$ positions are indicated by the solid circles. Other cations are in the octahedral positions. Structure: Rombohedral, Sp. gr. R3. Ceramics were prepared by hot pressing.

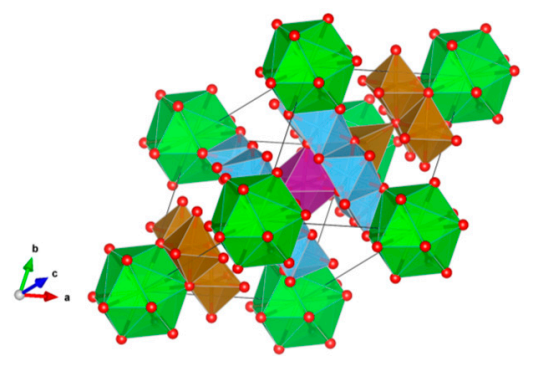

Figure 9. Crichtonite. $\mathrm{Sr}(\mathrm{Mn}, \mathrm{Y}, \mathrm{U}) \mathrm{Fe}_{2}(\mathrm{Ti}, \mathrm{Fe}, \mathrm{Cr}, \mathrm{V})_{18}(\mathrm{O}, \mathrm{OH})_{38}$. Structure rombohedral, Sp. gr. R3. Cations can be $\mathrm{Mg}$, Mn, Ni, Cu, Mn, $\mathrm{Sr}, \mathrm{Pb}, \mathrm{Cr}, \mathrm{Fe}, \mathrm{Y}, \mathrm{La}, \mathrm{Ce}, \mathrm{Ti}, \mathrm{Zr}, \mathrm{Hf}, \mathrm{U}, \mathrm{V}$ and $\mathrm{Nb}$.

10. Freudenbergite $[153,155,203,204]$, Figure 10.

$\mathrm{Na}_{2} \mathrm{Al}_{2}(\mathrm{Ti}, \mathrm{Fe})_{6} \mathrm{O}_{16}$ a spinel-based phase suitable for incorporating $\mathrm{Al}$-rich wastes from $\mathrm{Al}$ fuel cladding/decladding. The A site can accommodate $\mathrm{Na}$ and $\mathrm{K}$ while the different octahedral sites can accommodate $\mathrm{Mg}, \mathrm{Co}, \mathrm{Ni}, \mathrm{Zn}, \mathrm{Al}_{1} \mathrm{Ti}^{3+}, \mathrm{Cr}, \mathrm{Fe}, \mathrm{Ga}$, Si and Nb. Structure: Monocl., Sp. gr. C12/m1. Ceramics were prepared by cold pressing and sintering, $\rho=90 \%$.

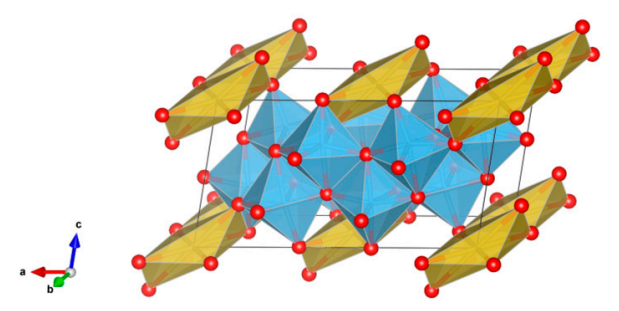

Figure 10. Freudenbergite (spinel). $\mathrm{Na}_{2} \mathrm{Al}_{2}(\mathrm{Ti}, \mathrm{Fe})_{6} \mathrm{O}_{16}$;. Structure monocl. Sp. gr. C12/m1. Cations can be $\mathrm{Na}, \mathrm{K}, \mathrm{Mg}, \mathrm{Co}, \mathrm{Ni}, \mathrm{Zn}, \mathrm{Al}, \mathrm{Ti}^{3+}, \mathrm{Cr}, \mathrm{Fe}, \mathrm{Ga}, \mathrm{Si}$ and $\mathrm{Nb}$.

11. P-Pollucite [205-215], Figure 11.

The ability of the pollucite structure to include large 1-, 2- and 3-valent cations allows flexibility to select the desired model composition. When replacing the cations it will be becomes possible to use cheap components; the introduction of small cations increases the concentration of cesium in the composition of the mono-phase product. Structure: Cubic, sp. gr. I4 ${ }_{1} 32, z=16$; may include: $\mathrm{Li}, \mathrm{Na}, \mathrm{K}$, $\mathrm{Rb}, \mathrm{Cs}, \mathrm{Tl}, \mathrm{Be}, \mathrm{Mg}$, Sr, Ba, Cd, Mn, Co, Ni, Cu, Zn, B, Al, Fe, Si, Ti, P, V, Nb and Ta. Compounds are hydrolytically and radiation-wise stable. Ceramics were prepared by cold pressing and sintering and Spark Plasma Sintering with high relative density (at last those up to 98-99\%).

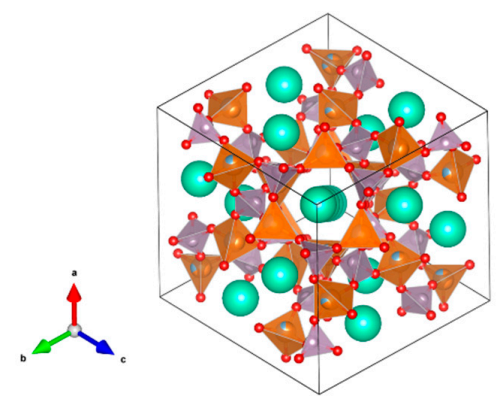

Figure 11. P-Pollucite. ( $\mathrm{Na}, \mathrm{K}, \mathrm{Rb}, \mathrm{Cs}) \mathrm{MgAl}_{0.5} \mathrm{P}_{1.5} \mathrm{O}_{6}$; Structure cubic, $\mathrm{Sp}$. gr. $\mathrm{I}_{1}$ 32. Cations can be Li, $\mathrm{Na}, \mathrm{K}, \mathrm{Rb}, \mathrm{Cs}, \mathrm{Tl}, \mathrm{Be}, \mathrm{Mg}, \mathrm{Mn}, \mathrm{Co}, \mathrm{Ni}, \mathrm{Cd}, \mathrm{Sr}, \mathrm{Ba}, \mathrm{Sr} . \mathrm{Ba}, \mathrm{B}, \mathrm{Al}, \mathrm{Fe}, \mathrm{Si}, \mathrm{Ti}, \mathrm{P}, \mathrm{V}, \mathrm{Nb}$ and Ta. 
12. Magnetoplumbites (aluminates) $[13,55,216-224]$, Figure 12.

Nominally $\mathrm{X}(\mathrm{Al}, \mathrm{Fe})_{12} \mathrm{O}_{19}$, where $\mathrm{X}=\mathrm{Sr}$, $\mathrm{Ba},\left(\mathrm{Cs}_{0.5}+\mathrm{La}_{0.5}\right)$ and $\left(\mathrm{Na}_{0.5}+\mathrm{La}_{0.5}\right)$. The $\mathrm{X}$ site is XII-fold coordinated and both $\mathrm{Cs}^{+} / \mathrm{Ba}^{2+}-\mathrm{Fe}^{3+} / \mathrm{Fe}^{2+}$ or $\mathrm{Cs}^{+} / \mathrm{Ba}^{2+}-\mathrm{Ti}^{4+} / \mathrm{Ti}^{3+}$ type substitutions can occur. Accommodating structures because they are composed of spinel blocks with both IV-fold and VI-fold coordinated sites for multivalent cations, and interspinel layers which have unusual V-fold sites for small cations. The interspinel layers also accommodate large cations of 1.15-1.84 $\AA$, replacing oxygen in XII-fold sites in the anion close packed structure. The large ions may be monovalent, divalent, or trivalent with balancing charge substitutions either in the interspinel layer $\left(\mathrm{Na}_{0.5}+\mathrm{La}_{0.5}\right)$ or between the interspinel layer and the spinel blocks $\left(\mathrm{Cs}^{+} / \mathrm{Ba}^{2+}-\mathrm{Fe}^{3+} / \mathrm{Fe}^{2+}\right.$ or $\left.\mathrm{Cs}^{+} / \mathrm{Ba}^{2+}-\mathrm{Ti}^{4+} / \mathrm{Ti}^{3+}\right)$. Structure: Hexagon., Sp. gr. $\mathrm{P}_{3} / \mathrm{mmc}$, $\mathrm{z}=2$; may include: $\mathrm{Na}, \mathrm{Cs}, \mathrm{Mg}$, $\mathrm{Sr}, \mathrm{Ba}, \mathrm{Pb}, \mathrm{Mn}, \mathrm{Co}, \mathrm{Cu}, \mathrm{Al}, \mathrm{Fe}, \mathrm{Sc}, \mathrm{Y}, \mathrm{La}$, $\mathrm{Ce}, \mathrm{Sm}, \mathrm{Gd}, \mathrm{Yb}, \mathrm{Lu}$, actinides, $\mathrm{Si}, \mathrm{Ti}$ and $\mathrm{Sn}$. Ceramics were prepared by cold pressing and sintering and by hot pressing.

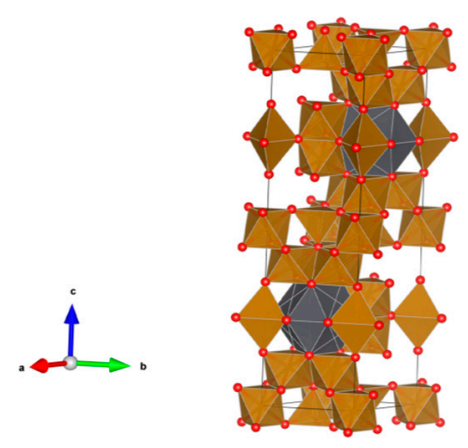

Figure 12. Magnetoplumbite. $\left(\mathrm{Sr}, \mathrm{Ba},\left((\mathrm{Na}, \mathrm{Cs})_{0.5}+\mathrm{La}_{0.5}\right)\right)(\mathrm{Al}, \mathrm{Fe})_{12} \mathrm{O}_{19}$. Structure hexagon., Sp. gr. $\mathrm{P} 63 /$ mmc. Cations can be $\mathrm{Na}, \mathrm{Cs}, \mathrm{Mg}$, Sr, Ba, Pb, Mn, Co, Cu, Al, Fe, Sc, Y, La, Ce, Sm, Gd, Yb, Lu, An, $\mathrm{Si}$, Ti and Sn.

\section{Zircon/Thorite/Coffinite [83,110,140,225-235], Figure 13.}

$\mathrm{ZrSiO}_{4} / \mathrm{ThSiO}_{4} / \mathrm{USiO}_{4}$; zircon is an extremely durable mineral that is commonly used for $\mathrm{U} / \mathrm{Pb}$ age-dating, as high uranium concentrations (up to 20,000 ppm) may be present; the $\mathrm{PuSiO}_{4}$ end member is known, and Ce, $\mathrm{Hf}$ and $\mathrm{Gd}$ have been found to substitute for Zr. Structure: Tetragon. Sp. gr. I41/amd, z = 4; may include: REE, Th, U, Pu; $\mathrm{Na}, \mathrm{Mg}, \mathrm{Ca}, \mathrm{Mn}, \mathrm{Co}, \mathrm{Fe}, \mathrm{Ti}, \mathrm{P}, \mathrm{V}$, Se and Mo. Ceramics were prepared by hot pressing, $\rho=99.1 \%$ and by Spark Plasma Sintering, $\rho=99 \%$

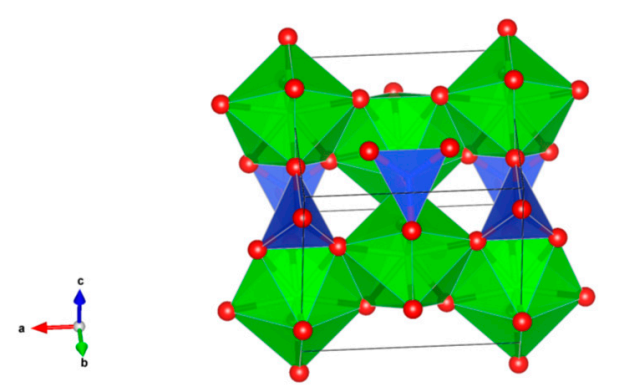

Figure 13. Zircon/Thorite/Coffinite. $\mathrm{ZrSiO}_{4} / \mathrm{ThSiO}_{4} / \mathrm{USiO}_{4}$. Structure tetragon., Sp. gr. I41/amd. Cations can be Na, Tl, Mg, Ca, Mn, Co, Fe, Ti, REE, Ti, Th, U, Pi, P, V, Mo and Se.

14. Titanite (sphene) [104,110,236-238], Figure 14.

$\mathrm{CaTiSiO}_{5}\left[\mathrm{CaTiO}\left(\mathrm{SiO}_{4}\right)\right]$. Structure: Monocl. Sp. gr. $\mathrm{P}_{2} \mathrm{I} / \mathrm{a}, \mathrm{Z}=4$; may include: $\mathrm{Mg}, \mathrm{Ca}, \mathrm{Sr}, \mathrm{Ba}, \mathrm{Mn}$, $\mathrm{Al}, \mathrm{Fe}, \mathrm{Cr}, \mathrm{Ce}, \mathrm{Y}, \mathrm{Zr}$, Th and $\mathrm{F}$. Ceramics are known as a matrix for actinide immobilization, and were prepared by cold pressing and sintering. 


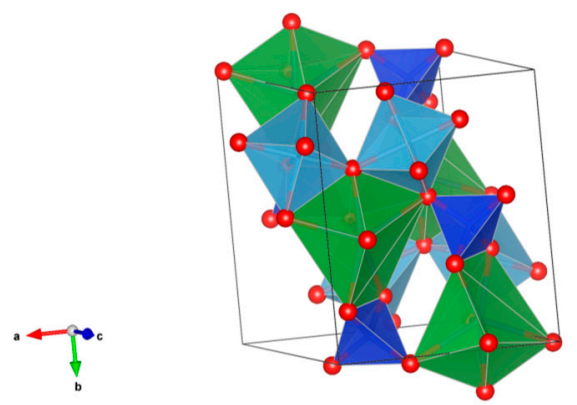

Figure 14. Titanite (sphene). $\mathrm{CaTiSiO}_{5}\left[\mathrm{CaTiO}\left(\mathrm{SiO}_{4}\right)\right]$. Structure monocl., Sp. gr. $\mathrm{P}_{2} \mathrm{I} / \mathrm{a}$. Cations can be $\mathrm{Mg}, \mathrm{Ca}, \mathrm{Sr}, \mathrm{Ba}, \mathrm{Mn}, \mathrm{Al}, \mathrm{Fe}, \mathrm{Cr}, \mathrm{Ce}, \mathrm{Y}, \mathrm{Zr}$, Th and F.

15. Britholite (silicate apatite; also known as oxy-apatite in the literature) [3,46,51,239-249], Figure 15 .

$(\mathrm{REE}, \mathrm{Ca})_{5}\left(\mathrm{SiO}_{4}, \mathrm{PO}_{4}\right)_{3}(\mathrm{OH}, \mathrm{F})$; i.e., $\mathrm{Ca}_{2} \mathrm{Nd}_{8}\left(\mathrm{SiO}_{4}\right)_{6} \mathrm{O}_{2}, \mathrm{Ca}_{2} \mathrm{La}_{8}\left(\mathrm{SiO}_{4}\right)_{6} \mathrm{O}_{2}$; based on ionic radii of $\mathrm{Nd}^{3+}, \mathrm{La}^{3+}$ and $\mathrm{Pu}^{3+}$, an extensive range of solubility for $\mathrm{Pu}^{3+}$ substitution for the $\mathrm{Nd}$ or La, particularly on the $6 h$ site, is expected. Since there is an extensive range in the $\mathrm{Ca} / \mathrm{RE}$ ratio in these silicate apatites, a fair amount of $\mathrm{Pu}^{4+}$ substitution may be possible; $\mathrm{La}^{3+}$ through $\mathrm{Lu}^{3+}$ can substitute for $\mathrm{Ca}^{2+}$ and form oxyapatites, $\mathrm{RE}_{4.67} \square_{0.33}\left[\mathrm{SiO}_{4}\right]_{3} \mathrm{O}$; can also accommodate $\mathrm{Cs}, \mathrm{Sr}, \mathrm{B}$, Th, $\mathrm{U}$ and Np. Structure: Monocl., Sp. gr. $\mathrm{P} 2{ }_{1}$ and hexagon. Sp. gr. $\mathrm{P}_{3} / \mathrm{m}$. Ceramics were prepared by cold pressing and sintering, $\rho=95 \%$.

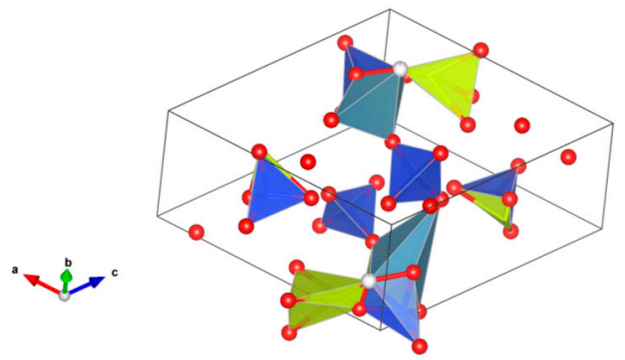

Figure 15. Britholite (silicate apatite, oxy-apatite). (REE,Ca) $)_{5}\left(\mathrm{SiO}_{4}, \mathrm{PO}_{4}\right)_{3}(\mathrm{OH}, \mathrm{F})-$ Structure monoclin. Sp. gr. P2 $1 /$ hexagonal, Sp. gr. $\mathrm{P}_{3} / \mathrm{m}$. Cations can be $\mathrm{Cs}, \mathrm{Sr}, \mathrm{B}, \mathrm{REE}, \mathrm{Th}, \mathrm{U}, \mathrm{Np}$ and $\mathrm{Pu}$.

\subsection{Framework Silicates}

16. Zeolites [75,250-266], Figure 16.

$\left(\mathrm{X}_{\mathrm{x} / \mathrm{n}}\left[\left(\mathrm{AlO}_{2}\right)_{\mathrm{x}}\left(\mathrm{SiO}_{2}\right)_{\mathrm{y}}\right]\right.$ where $\mathrm{X}$ is the charge balancing counter-ion, $\mathrm{n}$ is the charge of the counter-ion, $\mathrm{x}$ is the number of charge-deficient alumina sites, and $\mathrm{y}$ is the number of charge-neutral silica sites. Zeolites are characterized by internal voids, channels, pores, and/or cavities of well-defined size in the nanometer range, $\approx 4-13 \AA$. The channels and/or cavities may be occupied by charge compensating ions and water molecules. Zeolites like Ag-Mordenite selectively sorbs $\mathrm{I}_{2}\left({ }^{129} \mathrm{I}\right)$; certain zeolites can be converted to condensed oxide ceramics by heating. This process is particularly attractive for waste-form synthesis because contaminants capture and immobilization is performed with minimal steps. Structure of Zeolite- $\mathrm{A}$ showing alternate $\mathrm{Al}$ and $\mathrm{Si}$ atom ordering but omitting the tetrahedral oxygens around each $\mathrm{Al}$ and $\mathrm{Si}$ may include $\mathrm{Na}, \mathrm{K}, \mathrm{NH}_{4}{ }^{+}, \mathrm{Cs}, \mathrm{Mg}, \mathrm{Ca}, \mathrm{Sr}, \mathrm{Co}, \mathrm{Fe}, \mathrm{Ga}, \mathrm{REE}$ and Ti. 45 natural zeolites and 100 artificial ones are known. Ceramics were prepared by hot pressing. 


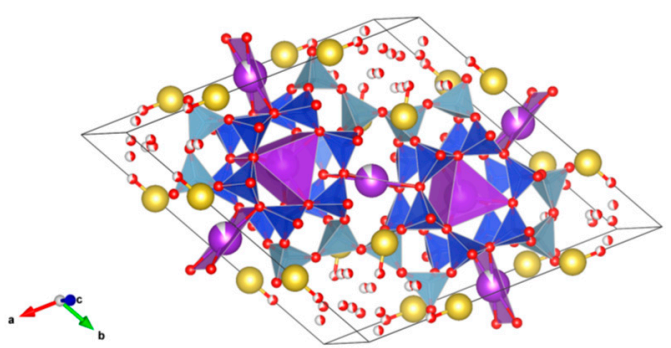

Figure 16. Zeolites. $\mathrm{X}_{\mathrm{x} / \mathrm{n}}\left[\left(\mathrm{AlO}_{2}\right)_{\mathrm{x}}\left(\mathrm{SiO}_{2}\right)_{\mathrm{y}}\right]$ (where $\mathrm{Xn}+$ is the charge balancing counter-ion). Structure depends on chemical composition. Cations can be $\mathrm{Na}, \mathrm{K}, \mathrm{NH}^{4+}, \mathrm{Cs}, \mathrm{Mg}, \mathrm{Ca}, \mathrm{Sr}, \mathrm{Co}, \mathrm{Fe}, \mathrm{Ga}$, REE and Ti.

17. Pollucite $[37,87,212,214,215,259,267-293]$, Figure 17.

$(\mathrm{Ca}, \mathrm{Na})_{2} \mathrm{Al}_{2} \mathrm{Si}_{4} \mathrm{O}_{12} \cdot 2 \mathrm{H}_{2} \mathrm{O}$; host for fission products such as ${ }^{137} \mathrm{Cs}$. Structure: Cubic, Sp. gr. Ia3d, $\mathrm{z}=16$; may include: $\mathrm{Li}, \mathrm{Na}, \mathrm{K}, \mathrm{Rb}, \mathrm{Cs}, \mathrm{Tl}, \mathrm{Be}, \mathrm{Mg}, \mathrm{Sr}, \mathrm{Ba}, \mathrm{Cd}, \mathrm{Mn}, \mathrm{Co}, \mathrm{Ni}, \mathrm{Cu}, \mathrm{Zn}, \mathrm{B}, \mathrm{Al}, \mathrm{Fe}, \mathrm{Si}, \mathrm{Ti}, \mathrm{P}$, $\mathrm{V}$ and $\mathrm{Nb}$. Ceramics were prepared by Spark Plasma Sintering with high relative density (up to $96 \%$ ).

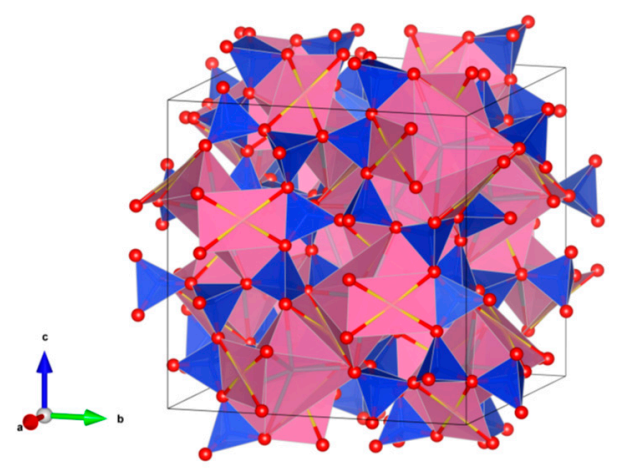

Figure 17. Pollucite. $(\mathrm{Ca}, \mathrm{Na})_{2} \mathrm{Al}_{2} \mathrm{Si}_{4} \mathrm{O}_{12} \cdot 2 \mathrm{H}_{2} \mathrm{O}$. Structure cubic, Sp. gr. Ia3d. Cations can be $\mathrm{Li}, \mathrm{Na}, \mathrm{K}$, $\mathrm{Rb}, \mathrm{Cs}, \mathrm{Tl}, \mathrm{Be}, \mathrm{Mg}, \mathrm{Sr}, \mathrm{Ba}, \mathrm{Cd}, \mathrm{Mn}, \mathrm{Co}, \mathrm{Ni}, \mathrm{Cu}, \mathrm{Zn}, \mathrm{B}, \mathrm{Al}, \mathrm{Fe}, \mathrm{Si}, \mathrm{Ti}, \mathrm{P}, \mathrm{V}$ and $\mathrm{Nb}$.

18. Nepheline/Leucite [37,58,61,73,155,294-297], Figure 18.

$\mathrm{NaAlSiO}_{4}$ silica "stuffed derivative" ring type structure; some polymorphs have large nine-fold cation cage sites, while others have 12-fold cage-like voids that can hold large cations (Cs, K, Ca). Natural nepheline structure accommodates $\mathrm{Fe}, \mathrm{Ti}$ and $\mathrm{Mg}$. Two-dimensional representation of the structure of nepheline showing the smaller 8 oxygen sites that are occupied by $\mathrm{Na}$ and the larger 9 oxygen sites that are occupied by $\mathrm{K}$ and larger ions, such as $\mathrm{Cs}$ and $\mathrm{Ca}$. Structure may include: $\mathrm{Li}, \mathrm{Na}$, $\mathrm{K}, \mathrm{Rb}, \mathrm{Cs}, \mathrm{Be}, \mathrm{Mg}, \mathrm{Ca}, \mathrm{Ba}, \mathrm{Pb}, \mathrm{Mn}, \mathrm{Co}, \mathrm{Ni}, \mathrm{Al}, \mathrm{Fe}, \mathrm{Cr}, \mathrm{Si}$, Ti and V. Structure: Hexagon. Sp. gr. $\mathrm{P}_{3}, \mathrm{z}=2$. Leucite. Structure: Tetragon. Sp. gr. I4 $1 /$ a and $\mathrm{I}_{1} / \mathrm{acd}$; cubic, Sp. gr. Ia3d, $\mathrm{z}=16$.

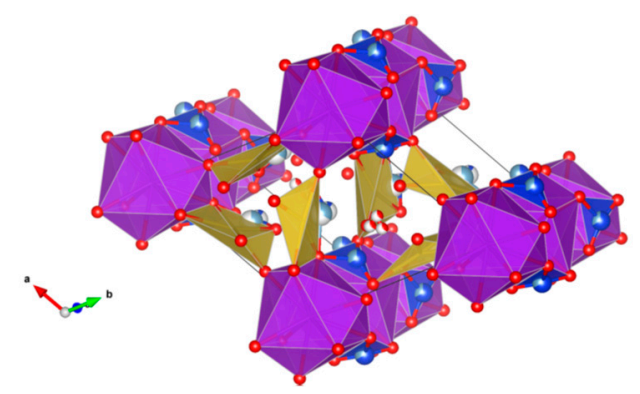

Figure 18. Nepheline/Leucite. ( $\mathrm{Na}, \mathrm{K}) \mathrm{AlSiO}_{4} / \mathrm{K}\left[\mathrm{AlSi}_{2} \mathrm{O}_{6}\right]$. Structure hexagon., Sp. gr. $\mathrm{P} 6_{3} /$ tetragonal, Sp. gr. $\mathrm{I}_{1} / \mathrm{a}$ and $\mathrm{I}_{1} / \mathrm{acd}$ or cubic, Sp. gr. Ia3d. Cations can be Li, $\mathrm{Na}, \mathrm{K}, \mathrm{Rb}, \mathrm{Cs}, \mathrm{Be}, \mathrm{Mg}, \mathrm{Ca}, \mathrm{Ba}, \mathrm{Pb}, \mathrm{Mn}$, $\mathrm{Co}, \mathrm{Ni} \mathrm{Al}, \mathrm{Fe}, \mathrm{Cr}, \mathrm{Si}$, Ti and V. 
19. Sodalite Group (name of mineral changes with anions sequestered in cage structure) [37,264,295,298-313], Figure 19.

(1) Sodalite $\mathrm{Na}_{8} \mathrm{Cl}_{2} \mathrm{Al}_{6} \mathrm{Si}_{6} \mathrm{O}_{24}$, also written as $(\mathrm{Na}, \mathrm{K})_{6}\left[\mathrm{Al}_{6} \mathrm{Si}_{6} \mathrm{O}_{24}\right] \cdot(2 \mathrm{NaCl})$ to demonstrate that $2 \mathrm{Cl}$ and associated $\mathrm{Na}$ atoms are in a cage structure defined by the aluminosilicate tetrahedra of six adjoining $\mathrm{NaAlSiO}_{4}$, is a naturally occurring feldspathoid mineral. It incorporates alkali, alkaline earths, rare earth elements, halide fission products and trace quantities of $U$ and $\mathrm{Pu}$. Sodalite was and it is being investigated as a durable host for the waste generated from electro-refining operations deployed for the reprocessing of metal fuel. Supercalcines which are high temperature, silicate-based "natural mineral" assemblages proposed for HLW waste stabilization in the United States in 1973-1985, contained sodalites as minor phases retaining $\mathrm{Cs}$, $\mathrm{Sr}$ and Mo, e.g., $\mathrm{Na}_{6}\left[\mathrm{Al}_{6} \mathrm{Si}_{6} \mathrm{O}_{24}\right]\left(\mathrm{NaMoO}_{4}\right)_{2}$. Sodalite structures are known to retain $\mathrm{B}, \mathrm{Ge}, \mathrm{I}, \mathrm{Br}$ and $\mathrm{Re}$ in the cage-like structures. Structure of Sodalite showing (a) two-dimensional projection of the (b) three-dimensional structure and (c) the four fold ionic coordination of the $\mathrm{Na}$ site to the $\mathrm{Cl}$-ion and three framework oxygen bonds. Structure: Cubic, Sp. gr. $P_{\overline{4}} 3 n, \mathrm{z}=1$; may include: $\mathrm{Na}, \mathrm{K}, \mathrm{Mg}, \mathrm{Ca}, \mathrm{Mn}, \mathrm{Fe}, \mathrm{Al}, \mathrm{Si}, \mathrm{Ti}, \mathrm{Cl}, \mathrm{SO}_{4}$ and $\mathrm{CO}_{3}$. Ceramics were prepared by cold pressing and sintering; by HIP.

(2) Nosean, $\left.(\mathrm{Na}, \mathrm{K})_{6}\left[\mathrm{Al}_{6} \mathrm{Si}_{6} \mathrm{O}_{24}\right]\left(\mathrm{Na}_{2} \mathrm{SO}_{4}\right)\right)$, silica "stuffed derivative" sodalite cage type structure host mineral for sulfate or sulfide species.

(3) Hauyne, $(\mathrm{Na})_{6}\left[\mathrm{Al}_{6} \mathrm{Si}_{6} \mathrm{O}_{24}\right]\left((\mathrm{Ca}, \mathrm{Na}) \mathrm{SO}_{4}\right)_{1-2}$ sodalite family; can accommodate either $\mathrm{Na}_{2} \mathrm{SO}_{4}$ or $\mathrm{CaSO}_{4}$.

(4) Helvite $\left(\mathrm{Mn}_{4}\left[\mathrm{Be}_{3} \mathrm{Si}_{3} \mathrm{O}_{12}\right] \mathrm{S}\right.$ : Be (beryllium) can be substituted in place of $\mathrm{Al}$ and $\mathrm{S}_{2}$ in the cage structure along with $\mathrm{Fe}, \mathrm{Mn}$ and $\mathrm{Zn}$.

(5) Danalite $\left(\mathrm{Fe}_{4}\left[\mathrm{Be}_{3} \mathrm{Si}_{3} \mathrm{O}_{12}\right] \mathrm{S}\right)$.

(6) Genthelvite $\left(\mathrm{Zn}_{4}\left[\mathrm{Be}_{3} \mathrm{Si}_{3} \mathrm{O}_{12}\right] \mathrm{S}\right)$.

(7) Lazurite, $(\mathrm{Ca}, \mathrm{Na})_{6}\left[\mathrm{Al}_{6} \mathrm{Si}_{6} \mathrm{O}_{24}\right]\left((\mathrm{Ca}, \mathrm{Na}) \mathrm{S}, \mathrm{SO}_{4}, \mathrm{Cl}\right)_{\times}$; can accommodate either $\mathrm{SO}_{4}$ or $\mathrm{S}_{2}, \mathrm{Ca}$ or $\mathrm{Na}$ and $\mathrm{Cl}$.

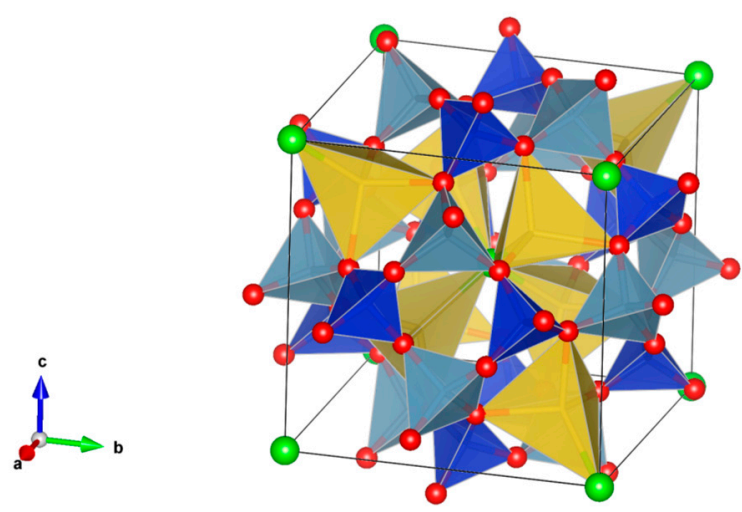

Figure 19. Sodalite.group minerals. Sodalite/Nosean/Hauyne/Helvite/Danalite/Genthelvite/Lazurite. $(\mathrm{Na}, \mathrm{K})_{6}\left[\mathrm{Al}_{6} \mathrm{Si}_{6} \mathrm{O}_{24}\right] \cdot(2 \mathrm{NaCl}) /(\mathrm{Na}, \mathrm{K})_{6}\left[\mathrm{Al}_{6} \mathrm{Si}_{6} \mathrm{O}_{24}\right]\left(\mathrm{Na}_{2} \mathrm{SO}_{4}\right) /(\mathrm{Na})_{6}\left[\mathrm{Al}_{6} \mathrm{Si}_{6} \mathrm{O}_{24}\right]\left((\mathrm{Ca}, \mathrm{Na}) \mathrm{SO}_{4}\right)_{1-2} /$ $\left(\mathrm{Mn}_{4}\left[\mathrm{Be}_{3} \mathrm{Si}_{3} \mathrm{O}_{12}\right] \mathrm{S} /\left(\mathrm{Fe}_{4}\left[\mathrm{Be}_{3} \mathrm{Si}_{3} \mathrm{O}_{12}\right] \mathrm{S}\right) /\left(\mathrm{Zn}_{4}\left[\mathrm{Be}_{3} \mathrm{Si}_{3} \mathrm{O}_{12}\right] \mathrm{S}\right) /(\mathrm{Ca}, \mathrm{Na})_{6}\left[\mathrm{Al}_{6} \mathrm{Si}_{6} \mathrm{O}_{24}\right]\left((\mathrm{Ca}, \mathrm{Na}), \mathrm{S}, \mathrm{SO}_{4}, \mathrm{Cl}\right)_{x}\right.$; Structure cubic, Sp. gr. P3n Cations and anions can be Na, K, Be, Mg, Ca, Mn, Fe, Al, Si, Ti, Cl, SO and $\mathrm{CO}_{3}$.

20. Cancrinite [37,314-319], Figure 20.

Cancrinite is a complex carbonate and silicate of sodium, calcium and aluminum with the formula $(\mathrm{Na}, \mathrm{Ca}, \mathrm{K})_{6}\left[\mathrm{Al}_{6} \mathrm{Si}_{6} \mathrm{O}_{24}\right]\left((\mathrm{Na}, \mathrm{Ca}, \mathrm{K})_{2} \mathrm{CO}_{3}\right)_{1.6} \cdot 2.1 \mathrm{H}_{2} \mathrm{O}$. It is classed as a member of the feldspathoid group of minerals. Cancrinite is unusual in that it is one of the few silicate minerals to have a carbonate ion 
$\left(\mathrm{CO}_{3}{ }^{2-}\right)$ present in its structure. Mineral cancrinite will also contain some percentages of sulfate ions $\left(\mathrm{SO}_{4}{ }^{2-}\right)$ and a chlorine ion $\left(\mathrm{Cl}^{-}\right)$. Structure: Hexagonal, Sp. gr. $\mathrm{P}_{3}$.

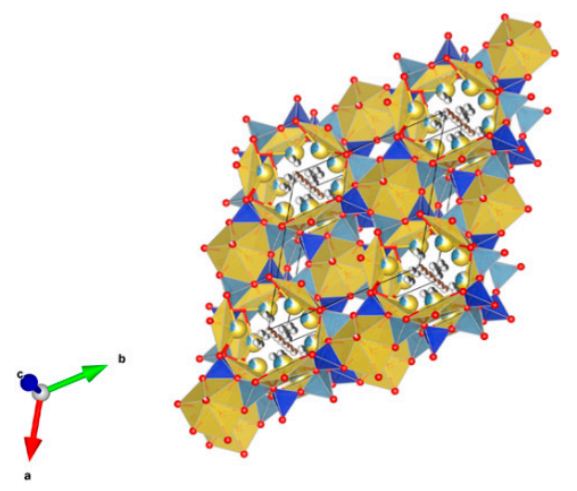

Figure 20. Cancrinite. $(\mathrm{Na}, \mathrm{Ca}, \mathrm{K})_{6}\left[\mathrm{Al}_{6} \mathrm{Si}_{6} \mathrm{O}_{24}\right]\left((\mathrm{Na}, \mathrm{Ca}, \mathrm{K})_{2} \mathrm{CO}_{3}\right)_{1.6} \cdot 2 \cdot 1 \mathrm{H}_{2} \mathrm{O}$. Structure hexagonal, Sp. gr. $\mathrm{P}_{3}$. Cations and anions can be $\mathrm{Na}, \mathrm{K}, \mathrm{Ca}$. $\mathrm{Al}, \mathrm{Si}, \mathrm{SO}_{4}$ and $\mathrm{Cl}$.

21. Crystalline SilicoTitanate (CST) [73,110,273-275,277,320-324], Figure 21.

$\left[(\mathrm{Ca}, \mathrm{N2a}, \mathrm{K}, \mathrm{Ba}) \mathrm{AlSiO}_{4}\right.$ incorporates $\mathrm{Na}, \mathrm{K}, \mathrm{Cs}, \mathrm{Ca}, \mathrm{Sr}, \mathrm{Ba}, \mathrm{Pb}, \mathrm{Al}, \mathrm{REE}, \mathrm{Bi}, \mathrm{Ti}, \mathrm{Zr}, \mathrm{Nb}$ and $\mathrm{Ta}$. Crystal structure of $\mathrm{Cs}$ exchanged $\mathrm{Nb}$-titanium silicate. Structure: Cubic, sp. gr. Pm3m up to $105^{\circ} \mathrm{C}$, after tetragon. Sp. gr. I4/mcm or $\mathrm{P}_{2} / \mathrm{mcm}$. Ceramics were prepared by hot isostatic pressing.

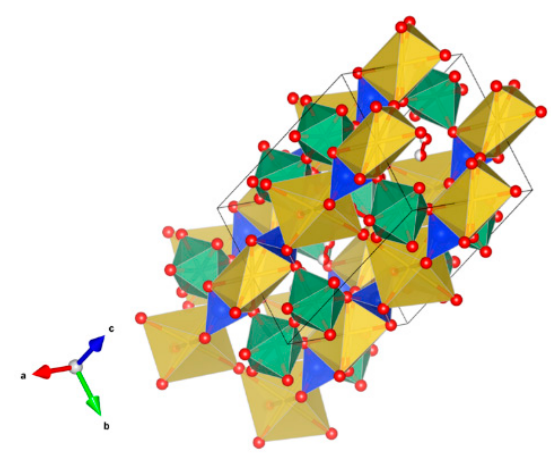

Figure 21. SilicoTitanate (CST). $\mathrm{SiTiO}_{4}$. Structure cubic, Sp. gr. Pm3m up to $105^{\circ} \mathrm{C}$, after-tetragonal Sp. gr. I4/mcm or $\mathrm{P} 42 / \mathrm{mcm}$. Cations can be $\mathrm{Na}, \mathrm{K}, \mathrm{Cs}, \mathrm{Ca}, \mathrm{Sr}, \mathrm{Ba}, \mathrm{Pb}, \mathrm{Al}, \mathrm{REE}, \mathrm{Bi}, \mathrm{Ti}, \mathrm{Zr}, \mathrm{Nb}$ and $\mathrm{Ta}$.

22. Micas (Dehydroxylated) [37,325-330], Figure 22.

The following dehydroxylated micas have been synthesized phase pure: $\mathrm{LiAl}_{3} \mathrm{Si}_{3} \mathrm{O}_{11}, \mathrm{NaAl}_{3} \mathrm{Si}_{3} \mathrm{O}_{11}$, $\mathrm{KAl}_{3} \mathrm{Si}_{3} \mathrm{O}_{11}, \quad \mathrm{RbAl}_{3} \mathrm{Si}_{3} \mathrm{O}_{11}, \quad \mathrm{CsAl}_{3} \mathrm{Si}_{3} \mathrm{O}_{11}, \quad \mathrm{TlAl}_{3} \mathrm{Si}_{3} \mathrm{O}_{11}, \quad \mathrm{Ca}_{0.5} \square_{0.5} \mathrm{Al}_{3} \mathrm{Si}_{3} \mathrm{O}_{11}, \quad \mathrm{Sr}_{0.5} \square_{0.5} \mathrm{Al}_{3} \mathrm{Si}_{3} \mathrm{O}_{11}$, $\mathrm{Ba}_{0.5} \square_{0.5} \mathrm{Al}_{3} \mathrm{Si}_{3} \mathrm{O}_{11}$ and $\mathrm{La}_{0.33} \square_{0.66} \mathrm{Al}_{3} \mathrm{Si}_{3} \mathrm{O}_{11}$. In the $\mathrm{Cs}$ mica up to $30 \mathrm{wt} \% \mathrm{Cs}_{2} \mathrm{O}$ can be accommodated, in the $\mathrm{Rb}$-mica up to $22 \mathrm{wt} \% \mathrm{Rb}_{2} \mathrm{O}$ can be accommodated, and in the Ba-mica up to $19 \mathrm{wt} \% \mathrm{BaO}$ can be accommodated. $\mathrm{Mg}, \mathrm{Fe}^{2+}, \mathrm{Fe}^{3+}, \mathrm{Mn}, \mathrm{Li}, \mathrm{Cr}, \mathrm{Ti}$ and $\mathrm{V}$ can substitute for VI-fold coordinated $\mathrm{Al}^{3+}$. Structure: Monoclinic. Sp. gr. C2/c. 


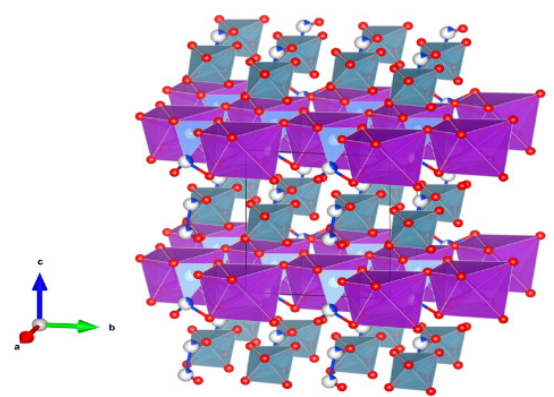

Figure 22. Micas (Dehydroxylated). $\mathrm{XY}_{2-3} \mathrm{Z}_{4} \mathrm{O}_{10}(\mathrm{OH}, \mathrm{F})_{2}$ with $\mathrm{X}=\mathrm{K}, \mathrm{Na}, \mathrm{Ba}, \mathrm{Ca}, \mathrm{Cs},\left(\mathrm{H}_{3} \mathrm{O}\right)$ and $\left(\mathrm{NH}_{4}\right)$; $\mathrm{Y}=\mathrm{Al}, \mathrm{Mg}, \mathrm{Fe}^{2+}, \mathrm{Li}, \mathrm{Cr}, \mathrm{Mn}, \mathrm{V}$ and $\mathrm{Zn}$; and $\mathrm{Z}=\mathrm{Si}, \mathrm{Al}, \mathrm{Fe}^{3+}, \mathrm{Be}$ and Ti. Structure monoclinic, Sp. gr. $\mathrm{C} 2 / \mathrm{c}$.

\subsection{Phosphates}

23. Monazite [12,16-18,87,89,140,141,231,235,244,293,331-359], Figure 23.

$\mathrm{CePO}_{4}$ or $\mathrm{LaPO}_{4}$ are corrosion-resistant materials and can incorporate a large range of radionuclides including actinides and toxic metals into its structure. Monazite was proposed as a potential host phase for excess weapons plutonium and radionuclides, and toxic metals in glass ceramic waste-forms for low-level and hazardous wastes. Monazite structure (monazite mineral $\mathrm{CePO}_{4}$ ) has wide capacity isomorphous through which the cerium and phosphorus can be substituted for other elements, e.g.,: $\mathrm{Ce} \rightarrow \mathrm{Li}, \mathrm{Na}, \mathrm{K}, \mathrm{Rb}, \mathrm{Mg}, \mathrm{Ca}, \mathrm{Sr}, \mathrm{Ba}, \mathrm{Cd}, \mathrm{Pb}, \mathrm{Bi}, \mathrm{Y}, \mathrm{La}, \mathrm{Pr}, \mathrm{Nd}, \mathrm{Sm}, \mathrm{Eu}, \mathrm{Gd}, \mathrm{Tb}, \mathrm{Yb}, \mathrm{Am}, \mathrm{Cm}, \mathrm{Cf}, \mathrm{Es}, \mathrm{Ge}$, $\mathrm{Zr}, \mathrm{Th}, \mathrm{Np}, \mathrm{U}$ and $\mathrm{Pu} ; \mathrm{P} \rightarrow \mathrm{Cr}, \mathrm{Si}, \mathrm{Se}, \mathrm{V}$, As and $\mathrm{S}$. Alternating chains of $\mathrm{PO}_{4}$ tetrahedra and $\mathrm{REO}_{9}$ polyhedra. Structure: Monoclinic. Sp. gr. $\mathrm{P} 21 / \mathrm{n}$. Ceramics were prepared by cold pressing and sintering $(\rho=90-95 \%)$, hot pressing $(\rho=97 \%)$ and Spark Plasma Sintering with high relative density (up to $98-99 \%$ ).

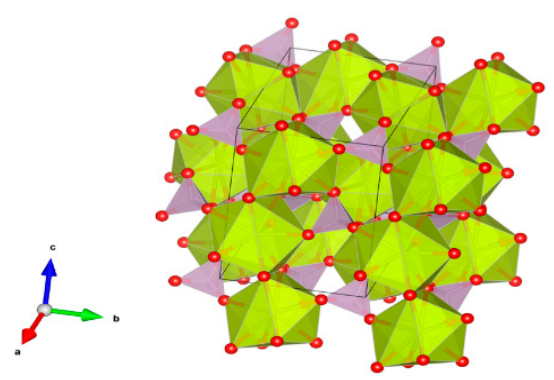

Figure 23. Monazite. (Ce, $\mathrm{La}, \mathrm{Nd}, \mathrm{Th})\left(\mathrm{PO}_{4}, \mathrm{SiO}_{4}\right)$. Structure monoclinic, Sp. gr. P21/n. Cations can be $\mathrm{Li}$, $\mathrm{Na}, \mathrm{K}, \mathrm{Rb}, \mathrm{Mg}$, Ca, Sr, Ba, Cd, Pb, Bi, Y, La, Pr, Nd, Sm, Eu, Gd, Tb, Yb, Am, Cm, Cf, Es, Ge, Zr, Th, U, $\mathrm{Np}, \mathrm{Pu}, \mathrm{Cm} ; \mathrm{Si}, \mathrm{Se}, \mathrm{V}$, As and $\mathrm{S}$.

24. Xenotime [231,334,344,360-363], Figure 24.

$\mathrm{YPO}_{4}$. Structure: Tetragonal. Sp.gr. $\mathrm{I}_{1} / \mathrm{amd}, \mathrm{z}=4, \mathrm{C} . \mathrm{N} . \mathrm{Y}-\mathrm{O}_{\mathrm{n}}, \mathrm{n}=8$. Isomorph including: Be, Ca, $\mathrm{Al}, \mathrm{Sc}, \mathrm{La}, \mathrm{Ce}, \mathrm{Er}, \mathrm{Dy}-\mathrm{Lu}, \mathrm{Zr}$, Th and U. Ceramics were prepared by cold pressing and sintering. 


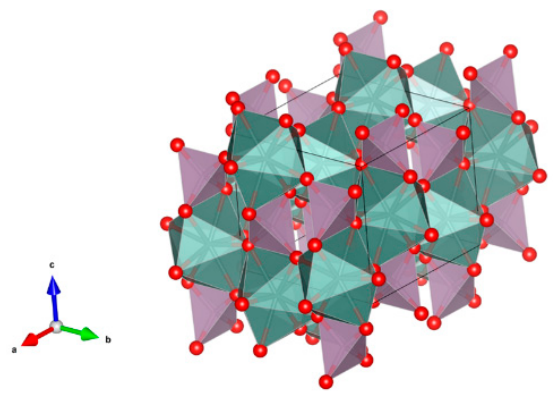

Figure 24. Xenotime $\left(\mathrm{YPO}_{4}\right)$. Ce, $\left.\mathrm{La}, \mathrm{Nd}, \mathrm{Th}\right)\left(\mathrm{PO}_{4}, \mathrm{SiO}_{4}\right)$. Structure tetragonal, Sp. gr. I41/amd. Cations can be Be, Ca, Al, Sc, La, Ce, Er, Dy-Lu, Zr, Th and U.

25. Apatite $[3,37,87,240,241,332,364-378]$, Figure 25 .

$\mathrm{Ca}_{4-\mathrm{x}} \mathrm{RE}_{6+\mathrm{x}}\left(\mathrm{SiO}_{4}\right)_{6-\mathrm{y}}\left(\mathrm{PO}_{4}\right)_{\mathrm{y}}(\mathrm{O}, \mathrm{F})_{2}$ can be actinide-host phases in HLW glass, glass-ceramic waste-forms, ceramic waste-forms and cements. The actinides can readily substitute in apatite for rare-earth elements as in $\mathrm{Ca}_{2}(\mathrm{Nd}, \mathrm{Cm}, \mathrm{Pu})_{8}\left(\mathrm{SiO}_{4}\right)_{6} \mathrm{O}_{2}$, and fission products are also readily incorporated. However, the solubility for tetravalent $\mathrm{Pu}$ may be limited without other charge compensating substitutions.

Apatite has been proposed as a potential host phase for $\mathrm{Pu}$ and high-level actinide wastes. Structure: Hexagonal, Sp. gr. $\mathrm{P}_{3} / \mathrm{m}$ or monoclinic, Sp. gr. $\mathrm{P} 2_{1} / \mathrm{b}$; may include: $\mathrm{Na}, \mathrm{K}, \mathrm{Cs}, \mathrm{Mg}, \mathrm{Ca}, \mathrm{Sr}$, $\mathrm{Ba}, \mathrm{Mn}, \mathrm{Ni}, \mathrm{Cd}, \mathrm{Hg}, \mathrm{Pb}, \mathrm{Cr}, \mathrm{Y}, \mathrm{REE}, \mathrm{Th}, \mathrm{U}, \mathrm{Si}, \mathrm{P}, \mathrm{V}, \mathrm{As}, \mathrm{S}, \mathrm{F}, \mathrm{Cl}, \mathrm{OH}$ and $\mathrm{CO}_{3}$. Ceramics were prepared by cold pressing and sintering, $\rho=95 \%$; by HIP.

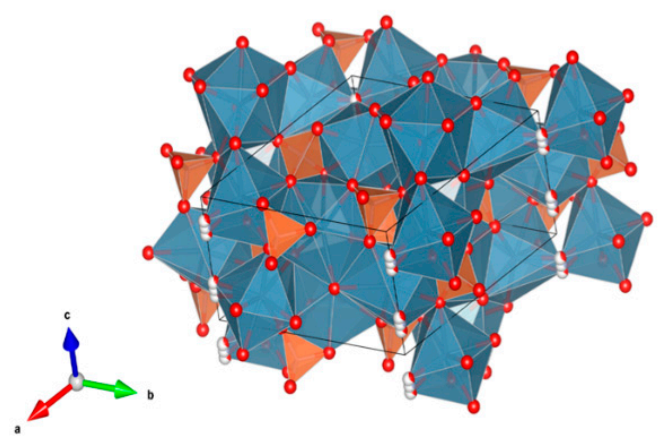

Figure 25. Apatite. $\mathrm{Ca}_{5}\left(\mathrm{PO}_{4}\right)_{3}(\mathrm{OH}, \mathrm{F}, \mathrm{Cl})$. Apatite. Structure hexagonal, Sp. gr. P63/m, monoclinic, Sp. gr. P21/b. Cations and anions can be Na, K, Cs, Mg, Ca, Mn, Ni, Sr, Ba, Cd, Hg, Pb, Cr, Y, REE, Cm, Si, Th, U, P, V, As, S, F, Cl, OH and $\mathrm{CO}_{3}$.

26. Sodium zirconium phosphate (NZP) [17-24,87,89,155,209,211,293,379-416], Figure 26.

The first studies of materials with such a structure were carried out by the authors [379-383] in 1976-1987. They substantiated the crystal-chemical approach when choosing the composition of substances and their structural modifications with ion-transforming properties ( $\mathrm{Li}+, \mathrm{Na}+$, etc.): NASICON, Langbeinite. Such materials have a frame structure: $\mathrm{Na}_{1}+{ }_{x} \mathrm{Zr}_{2} \mathrm{Si}_{\mathrm{x}} \mathrm{P}_{3-\mathrm{x}} \mathrm{O}_{12}, \mathrm{Na}_{3} \mathrm{M}_{2}\left(\mathrm{PO}_{4}\right)_{3}$ $(\mathrm{M}=\mathrm{Sc}, \mathrm{Cr}, \mathrm{Fe}), \mathrm{Na}_{5} \mathrm{Zr}\left(\mathrm{PO}_{4}\right)_{3}, \mathrm{Li}_{x} \mathrm{Fe}_{2}\left(\mathrm{WO}_{4}\right)_{3}, \mathrm{Li}_{x} \mathrm{Fe}_{2}\left(\mathrm{MoO}_{4}\right)_{3}$. Elements in oxidation states 3-6 were introduced into the frame positions: $\mathrm{Sc}, \mathrm{Cr}, \mathrm{Fe}, \mathrm{Si}, \mathrm{Zr}, \mathrm{P}, \mathrm{W}$ and Mo. It was also the first time in 1987 that the rationale for the use of such structural analogs for the consolidation of HLW and transmutation of minoractinides [384] was presented. The development of such materials-Structural analogues of NASICON, NZP, Langbeinite-and their research, was continued in subsequent years.

$\mathrm{NaZr}_{2}\left(\mathrm{PO}_{4}\right)_{3}$. The NZP structure can incorporate a complex variety of cations, including plutonium; a three dimensional network of corner-sharing $\mathrm{ZrO}_{6}$ octahedra and $\mathrm{PO}_{4}$ tetrahedra in which plutonium can substitute for $\mathrm{Zr}$, as in $\mathrm{Na}(\mathrm{Zr}, \mathrm{Pu})_{2}\left(\mathrm{PO}_{4}\right)_{3}$. Complete substitution of $\mathrm{Pu}^{4+}$ for $\mathrm{Zr}$ has been demonstrated in NZP. Cs and $\mathrm{Sr}$ can substitute for $\mathrm{Na}$, while fission products and actinides 
substitute for $\mathrm{Zr}$ in octahedral positions. $\mathrm{P}$ is tetrahedral. Phosphates with the mineral kosnarite structure $\left(\mathrm{NaZr}_{2}\left(\mathrm{PO}_{4}\right)_{3}\right.$ type, NZP) form a wide family. They can contain various cations in the oxidation state from $1+$ to $5+$. The structure consists of several positions and so many various cations can occupy it. These are $\mathrm{MI}=\mathrm{Li}, \mathrm{Na}, \mathrm{K}, \mathrm{Rb}, \mathrm{Cs} ; \mathrm{H}, \mathrm{Cu}(\mathrm{I})$ and $\mathrm{Ag}$; $\mathrm{MII}=\mathrm{Mg}, \mathrm{Ca}, \mathrm{Sr}, \mathrm{Ba}, \mathrm{Mn}, \mathrm{Co}, \mathrm{Ni}, \mathrm{Cu}$, $\mathrm{Zn}, \mathrm{Cd}$ and $\mathrm{Hg}$; MIII = Al, Ga, In, Sc, Y, La, Ce-Lu, Am, Cm, V, Cr, Fe, Sb and Bi; MIV = Ge, Sn, Ti, $\mathrm{Zr}, \mathrm{Hf}, \mathrm{Mo}, \mathrm{Ce}, \mathrm{Th}, \mathrm{U}, \mathrm{Np}$ and $\mathrm{Pu} ; \mathrm{MV}=\mathrm{Sb}, \mathrm{Nb}$ and Ta. Structure: Rhombohedral, Sp. gr. $R_{\overline{3}} c, \mathrm{R} 3 \mathrm{c}$, R3. This fact is extremely important, and can be useful for the synthesis of single-phase crystalline products of the solidification of radioactive waste whose cationic composition, as a rule, is extremely complicated. Ceramics were prepared by cold pressing and sintering $(\rho=80-98 \%)$, hot pressing $(\rho=96 \%)$ and Spark Plasma Sintering with high relative density (up to 98-99.9\%).

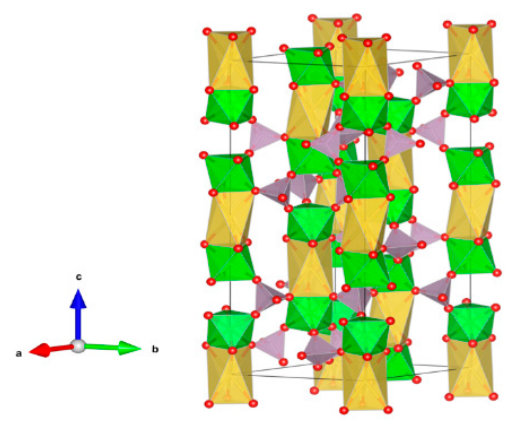

Figure 26. Sodium zirconium phosphate (NZP), $\mathrm{NaZr}_{2}\left(\mathrm{PO}_{4}\right)$. Structure rhombohedral, Sp. gr. Rc, R3c, R3. Cations can be Li, Na, K, Rb, Cs, Cu and Ag; Mg, Ca, Mn, Zn, Sr and Ba; Mn, Co, Ni, Cu, Zn and $\mathrm{Cd}$; Sc, Fe, Bi, Ce-Lu, Am and Cm; Zr, Hf, Th, U, Np and Pu; V, Nb, Sb and Ta; Ti, Ge, Zr, Hf, U, Np, Pu, Mo and Sn; Al, Sc, Cr, Fe, Ga, Y and In; Gd, Tb, Dy, Er and Yb; Mg; Na and K; Si, P, S, Mo and W.

27. Langbeinite $[18,87,89,211,293,416-420]$, Figure 27.

Langbeinite is a potassium magnesium sulfate mineral with the formula: $\mathrm{K}_{2} \mathrm{Mg}_{2}\left(\mathrm{SO}_{4}\right)_{3}$. It may include much of cesium and other large 1- and 2-valent elements. The structure is a framework type, also as for its kosnarite structure. Structure: Cubic, Sp. gr. $\mathrm{P} 2{ }_{1} 3$; may include: $\mathrm{Na}, \mathrm{K}, \mathrm{Rb}, \mathrm{Cs}, \mathrm{Tl}, \mathrm{NH}_{4}$, $\mathrm{Mg}$, Sr, Ba, Pb, Mn, Co, Ni, Zn, Al, Fe Cr, Ti ${ }^{3+}, \mathrm{Ga}, \mathrm{V}^{3+}$, Rh, In, REE, Bi, Sn, Ti, Zr, Hf, P, Nb, Ta and S. Ceramics were prepared by cold pressing and sintering, $\rho=88 \%$.

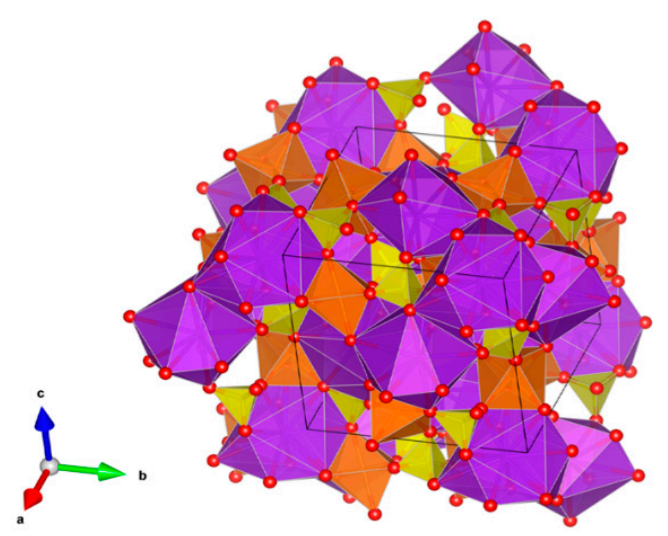

Figure 27. Langbeinite. $\mathrm{K}_{2} \mathrm{Mg}_{2}\left(\mathrm{SO}_{4}\right)_{3}$. Structure cubic, Sp. gr. $\mathrm{P} 2{ }_{1} 3$. Cations can be $\mathrm{Na}, \mathrm{K}, \mathrm{Rb}, \mathrm{Cs}, \mathrm{Tl}$, $\mathrm{NH}_{4}, \mathrm{Mg}, \mathrm{Sr}, \mathrm{Ba}, \mathrm{Pb}, \mathrm{Mn}, \mathrm{Co}, \mathrm{Ni}, \mathrm{Zn}, \mathrm{Al}, \mathrm{Fe} \mathrm{Cr}, \mathrm{Ti}^{3+}, \mathrm{Ga}, \mathrm{V}^{3+}$, Rh, In, REE, Bi, Sn, Ti, Zr, Hf, P, Nb, Ta and $S$.

28. Whitlockite [87,89,421-432], Figure 28.

Phosphates with the whitlockite structure (analog $\left.\beta-\mathrm{Ca}_{3}\left(\mathrm{PO}_{4}\right)_{2}\right)$ were proposed as matrices for radioactive waste immobilization. Their origin is both biogenic and cosmogenic. Whitlockite samples 
from meteorites, rocks of the Moon, Mars and other cosmogenic bodies, preserve the crystalline form under the action of natural thermal "stress" and cosmic radiation. They contain small amounts of uranium and thorium, and it is presumed to contain plutonium. It is known to form isostructural compounds with $\mathrm{H}, \mathrm{Li}, \mathrm{Na}, \mathrm{K}, \mathrm{Cu}, \mathrm{Mg}, \mathrm{Ca}, \mathrm{Sr}, \mathrm{Ba}, \mathrm{Al}, \mathrm{Sc}, \mathrm{Cr}, \mathrm{Fe}, \mathrm{Ga}$, In, $\mathrm{La}, \mathrm{Ce}, \mathrm{Sm}, \mathrm{Eu}, \mathrm{Gd}, \mathrm{Lu}$, Th and $\mathrm{Pu}$. Thermal stability is up to $1200^{\circ} \mathrm{C}$, thermal expansion up to $1 \times 10^{-5} \mathrm{deg}^{-1}\left(25-1000{ }^{\circ} \mathrm{C}\right)$ are close to Synroc and zirconolite; hydrothermal stable - leach rates at $90^{\circ} \mathrm{C}$ up to $10^{-5} \mathrm{~g} \cdot \mathrm{sm}^{-2} \cdot \mathrm{day}^{-1}$, radiation stable. Structure: Trigonal, Sp. gr. R3c. Ceramics were prepared by cold pressing and sintering $(\rho=92-97 \%)$ and Spark Plasma Sintering with high relative density (up to 95-98\%).
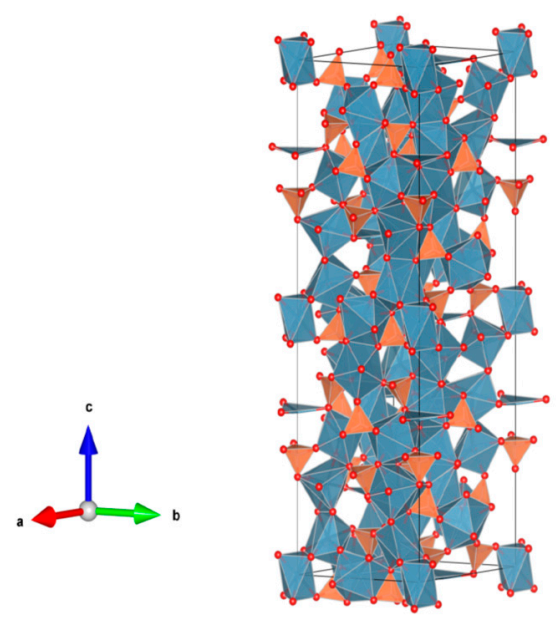

Figure 28. Whitlockite. $\mathrm{Ca}_{3}\left(\mathrm{PO}_{4}\right)_{2}$. Structure trigonal, Sp. gr. R3c.Cations can be $\mathrm{H}, \mathrm{Li}, \mathrm{Na}, \mathrm{K}, \mathrm{Cu}, \mathrm{Mg}$, $\mathrm{Ca}, \mathrm{Sr}, \mathrm{Ba}, \mathrm{Al}, \mathrm{Sc}, \mathrm{Cr}, \mathrm{Fe}, \mathrm{Ga}, \mathrm{In}, \mathrm{La}, \mathrm{Ce}, \mathrm{Sm}, \mathrm{Eu}, \mathrm{Gd}, \mathrm{Lu}, \mathrm{Th}, \mathrm{U}$ and Pu.

29. Thorium phosphate/Diphosphate (TPD) [155,244,336,337,433-439], Figure 29.

$\mathrm{Th}_{4}\left(\mathrm{PO}_{4}\right)_{4} \mathrm{P}_{2} \mathrm{O}_{7}$; a unique compound for the immobilization of plutonium and uranium; partial substitution of $\mathrm{Pu}$ for $\mathrm{Th}$ has been demonstrated to up to 0.4 mole fraction, complete substitution is not possible. Structure: Orthorhombic, Sp. gr. Pbcm, Pcam, $\mathrm{z}=2$; may include: $\mathrm{U}, \mathrm{Np}, \mathrm{Pu}, \mathrm{Am}$ and $\mathrm{Cm}$. Ceramics were prepared by cold pressing and sintering $(\rho=87-93 \%)$.

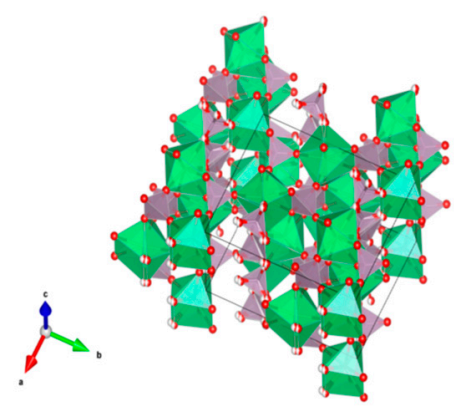

Figure 29. Thorium phosphate/Diphosphate (TPD). $\mathrm{Th}_{4}\left(\mathrm{PO}_{4}\right)_{4} \mathrm{P}_{2} \mathrm{O}_{7}$. Structure orthorhombic. Sp. gr. $\mathrm{Pbcm}$ and Pcam. Cations can be U, Np, Pu, Am and $\mathrm{Cm}$.

\subsection{Tungstate, Molybdates}

30. Scheelite [89,440-457], Figure 30.

Materials with the structure of the scheelite mineral (calcium tungstate $\mathrm{CaWO}_{4}$ ) based on individual molybdates and tungstates and solid solutions may contain elements in oxidation degrees from 1+ to 7+: $\mathrm{Li}, \mathrm{Na}, \mathrm{K}, \mathrm{Rb}, \mathrm{Cs}$ and $\mathrm{Tl} ; \mathrm{Ca}, \mathrm{Sr}, \mathrm{Ba}, \mathrm{Mn}$ and $\mathrm{Cu} ; \mathrm{Fe}, \mathrm{Ce}, \mathrm{La}-\mathrm{Lu}$ and $\mathrm{Y} ; \mathrm{Th}, \mathrm{U}, \mathrm{Np}$ and $\mathrm{Pu} ; \mathrm{Nb}$, Ta-in Ca-positions and Mo, W, Re, I, V and Ge in W-positions. The structural analog $\mathrm{CaWO}_{4}$ crystallizes in the tetragonal structure, Sp. gr. I4/c. The structure is constructed of $\mathrm{CaO}_{8}$ polyhedral 
and $\mathrm{WO}_{4}$ tetrahedrals connected through common oxygen vertices. For some compounds ceramics were prepared by the Spark Plasma Sintering (SPS) method, with a relative density of $92 \%$.

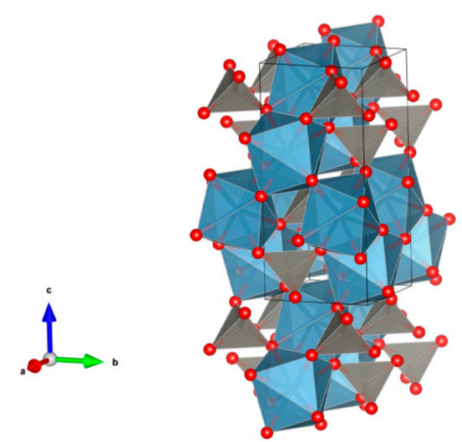

Figure 30. Scheelite. $\mathrm{CaWO}_{4}$. Structure tetragonal, Sp. gr. I4/c. Cations can be $\mathrm{Li}, \mathrm{Na}, \mathrm{K}, \mathrm{Rb}, \mathrm{Cs}, \mathrm{Tl}, \mathrm{Ca}$, $\mathrm{Sr}, \mathrm{Ba}, \mathrm{Mn}, \mathrm{Cu}, \mathrm{Fe}, \mathrm{Ce}, \mathrm{La}-\mathrm{Lu}, \mathrm{Y}, \mathrm{Ge}, \mathrm{Th}, \mathrm{U}, \mathrm{Np}, \mathrm{Pu}, \mathrm{Nb}, \mathrm{Ta}, \mathrm{V}, \mathrm{Mo}, \mathrm{W}, \mathrm{Re}$ and I.

\section{Summary of Crystalline Ceramic Waste-forms}

Crystalline materials including oxides-simple and complex, salts-silicates, phosphates, tungstates with various compositions and different structural modifications (30 structure forms) intended for nuclear waste immobilization were developed using various approaches and accounting for criteria of enough high durability (see e.g., $[15,238,458-460]$ ) requested for nuclear wasteforms. These are presented in Table 1. 
Table 1. Crystalline ceramic materials as potential forms for nuclear waste immobilization.

\begin{tabular}{|c|c|c|c|c|}
\hline \multirow{2}{*}{\multicolumn{2}{|c|}{ Type of Chemical Compound }} & \multicolumn{2}{|c|}{ Structure } & \multirow{2}{*}{ Compound Cations } \\
\hline & & Structural Type & Syngony, Sp. gr. & \\
\hline \multicolumn{5}{|c|}{ Oxide Compounds } \\
\hline \multirow{4}{*}{$\begin{array}{l}\text { Simple } \\
\text { oxides }\end{array}$} & $\mathrm{SiO}_{2}$ & Silica & rhombohedral, R3 & $\begin{array}{l}\mathrm{Li}, \mathrm{Na}, \mathrm{K} . \mathrm{Mg}, \mathrm{Ca}, \mathrm{Mn}, \mathrm{Cu}, \mathrm{Ni}, \mathrm{Pb} \mathrm{B}, \\
\mathrm{Al}, \mathrm{Fe}, \mathrm{Cr}, \mathrm{Ti}, \mathrm{Zr}, \mathrm{Te}\end{array}$ \\
\hline & $\mathrm{CeO}_{2}$ & Fluorite & cubic, Fm3m & $\mathrm{Cs}, \mathrm{Sr}, \mathrm{Ce}, \mathrm{Y}, \mathrm{Zr}, \mathrm{U}, \mathrm{Th}, \mathrm{Hf}, \mathrm{Pu}, \mathrm{U}, \mathrm{Np}$ \\
\hline & $\mathrm{A}_{2} \mathrm{~B}_{2} \mathrm{O}_{7}$ & Pyrochlore & cubic, $F d_{3} m$ & $\begin{aligned} \text { A: } \mathrm{Na}, \mathrm{Ca}, \mathrm{U}, \mathrm{Th}, \mathrm{Y}, \mathrm{Ln} ; \mathrm{B}: \mathrm{Nb}, \mathrm{Ta}, \mathrm{Ti}, \\
$\[ \mathrm{Zr}, \mathrm{Fe}^{3+} \]$\end{aligned}$ \\
\hline & $\begin{array}{l}\mathrm{A}_{6} \mathrm{~B}_{12} \mathrm{C}_{5} \mathrm{TX}_{40-\mathrm{x}} \\
\mathrm{CaZrTi}{ }_{2} \mathrm{O}_{7}\end{array}$ & $\begin{array}{l}\text { Murataite } \\
\text { Zirconolite }\end{array}$ & $\begin{array}{l}\text { cubic, } F 4-m \\
\text { trigonal } \mathrm{C} 2 / \mathrm{c}\end{array}$ & $\begin{array}{l}\text { U, Np, Pu, Am, Cm, REE } \\
\text { Gd, Hf, Ce, Th, U, Pu, Nb }\end{array}$ \\
\hline \multirow{11}{*}{$\begin{array}{l}\text { Complex } \\
\text { oxides }\end{array}$} & $\mathrm{CaTiO}_{3}$ & Perovskite & $\begin{array}{l}\text { cubic, Pm3m; } \\
\text { rhombohedral, Pnma }\end{array}$ & $\mathrm{Ca}, \mathrm{Y}, \mathrm{REE}, \mathrm{Ti}, \mathrm{Zr}, \mathrm{U}, \mathrm{Pu}$ \\
\hline & $\mathrm{Ba}_{1.2}(\mathrm{Al}, \mathrm{Ti})_{8} \mathrm{O}_{16}$ & Hollandite & tetragonal, I4/m & $\begin{array}{c}\mathrm{Na}, \mathrm{K}, \mathrm{Cs}, \mathrm{Mg}, \mathrm{Ca}, \mathrm{Ba}, \mathrm{Al}, \mathrm{Fe}, \mathrm{Mn}^{3+} \\
\mathrm{Si}, \mathrm{Ti}, \mathrm{Mn}^{4+}\end{array}$ \\
\hline & ${ }^{[8]}(\mathrm{Ca}, \mathrm{Gd}, \text { actinides })^{[6]} \mathrm{Fe}_{2}{ }^{[6]} \mathrm{Fe}_{3} \mathrm{O}_{12}$ & Garnet & cubic, Ia3d & $\begin{array}{l}\text { A, B: REE, } \mathrm{An}, \mathrm{Y}, \mathrm{Mg}, \mathrm{Ca}, \mathrm{Fe}^{2+}, \mathrm{Mn}^{2+} \\
\mathrm{X}: \mathrm{Cr}^{3+}, \mathrm{Fe}^{3+}, \mathrm{Al}^{3+}, \mathrm{Ga}^{3+}, \mathrm{Si}^{4+}, \mathrm{Ge}^{4+},\end{array}$ \\
\hline & $(\mathrm{Sr}, \mathrm{Pb}, \mathrm{La}, \mathrm{Ce}, \mathrm{Y})\left(\mathrm{Ti}_{1}, \mathrm{Fe}^{3+}, \mathrm{Mn}, \mathrm{Mg}, \mathrm{Zn}, \mathrm{Cr}, \mathrm{Al}, \mathrm{Zr}, \mathrm{Hf}, \mathrm{U}, \mathrm{V}, \mathrm{Nb}, \mathrm{Sn}, \mathrm{Cu}, \mathrm{Ni}\right)_{21} \mathrm{O}_{38}$ & Crichtonite & rhombohedral, R3 & \\
\hline & $\mathrm{Na}_{2} \mathrm{Al}_{2}(\mathrm{Ti}, \mathrm{Fe})_{6} \mathrm{O}_{16}$ & $\begin{array}{l}\text { Freudenbergite } \\
\text { spinel based phase }\end{array}$ & monoclinic, $\mathrm{C} 12 / \mathrm{m} 1$ & 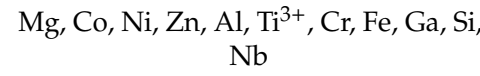 \\
\hline & & P-Pollucite & cubic, $\mathrm{I}_{1} 32$ & $\begin{array}{c}\mathrm{Li}, \mathrm{Na}, \mathrm{K}, \mathrm{Rb}, \mathrm{Cs}, \mathrm{Tl}, \mathrm{Be}, \mathrm{Mg}, \mathrm{Sr}, \mathrm{Ba} \\
\mathrm{Cd}, \mathrm{Mn}, \mathrm{Co}, \mathrm{Ni}, \mathrm{Cu}, \mathrm{Zn}, \mathrm{B}, \mathrm{Al}, \mathrm{Fe}, \mathrm{Si}, \\
\mathrm{Ti}, \mathrm{P}, \mathrm{V}, \mathrm{Nb}, \mathrm{Ta}\end{array}$ \\
\hline & $\mathrm{ZrSiO}_{4} / \mathrm{ThSiO}_{4} / \mathrm{USiO}_{4}$ & Zircon/Thorite/Coffinite & tetragonal, I41/amd & $\begin{array}{c}\text { REE, Th, U, Pu; Na, Mg, Ca, Mn, Co, } \\
\text { Fe, Ti, P, V, Se, Mo }\end{array}$ \\
\hline & $\mathrm{CaTiSiO}_{5}\left[\mathrm{CaTiO}\left(\mathrm{SiO}_{4}\right)\right]$ & Titanite (sphene) & monoclinic, $\mathrm{P}_{2} \mathrm{I} / \mathrm{a}$ & $\begin{array}{c}\mathrm{Mg}, \mathrm{Ca}, \mathrm{Sr}, \mathrm{Ba}, \mathrm{Mn}, \mathrm{Al}, \mathrm{Fe}, \mathrm{Cr}, \mathrm{Ce}, \mathrm{Y} \\
\mathrm{Zr}, \mathrm{Th}, \mathrm{F}\end{array}$ \\
\hline & $(\mathrm{REE}, \mathrm{Ca})_{5}\left(\mathrm{SiO}_{4}, \mathrm{PO}_{4}\right)_{3}(\mathrm{OH}, \mathrm{F})$ & Britholite (oxy-apatite) & $\begin{array}{l}\text { monoclinic, sp. gr. } \mathrm{P} 2{ }_{1} \\
\text { hexagonal, } \mathrm{P} 6_{3} / \mathrm{m}\end{array}$ & $\mathrm{Cs}, \mathrm{Sr}, \mathrm{B}, \mathrm{Th}, \mathrm{U}, \mathrm{Np}, \mathrm{Nd}^{3+}, \mathrm{La}^{3+}, \mathrm{Pu}^{3+}$ \\
\hline & \multicolumn{3}{|c|}{ Salt compounds } & \\
\hline & $\left(\mathrm{X}_{\mathrm{x} / \mathrm{n}}\left[\left(\mathrm{AlO}_{2}\right)_{\mathrm{x}}\left(\mathrm{SiO}_{2}\right)_{\mathrm{y}}\right]\right.$ & Zeolites & & $\begin{array}{c}\mathrm{Na}, \mathrm{K}, \mathrm{NH}_{4}{ }^{+}, \mathrm{Cs}, \mathrm{Mg}, \mathrm{Ca}, \mathrm{Sr}, \mathrm{Co}, \mathrm{Fe}, \\
\mathrm{Ga}, \mathrm{REE}, \mathrm{Ti}\end{array}$ \\
\hline $\begin{array}{l}\text { Framework } \\
\text { Silicates }\end{array}$ & $(\mathrm{Ca}, \mathrm{Na})_{2} \mathrm{Al}_{2} \mathrm{Si}_{4} \mathrm{O}_{12} \cdot 2 \mathrm{H}_{2} \mathrm{O}$ & Pollucite & cubic, Ia3d & $\begin{array}{l}\mathrm{Li}, \mathrm{Na}, \mathrm{K}, \mathrm{Rb}, \mathrm{Cs}, \mathrm{Tl}, \mathrm{Be}, \mathrm{Mg}, \mathrm{Sr}, \mathrm{Ba} \\
\mathrm{Cd}, \mathrm{Mn}, \mathrm{Co}, \mathrm{Ni}, \mathrm{Cu}, \mathrm{Zn}, \mathrm{B}, \mathrm{Al}, \mathrm{Fe}, \mathrm{Si}, \\
\mathrm{Ti}, \mathrm{P}, \mathrm{V}, \mathrm{Nb}\end{array}$ \\
\hline
\end{tabular}


Table 1. Crystalline ceramic materials as potential forms for nuclear waste immobilization.

\begin{tabular}{|c|c|c|c|c|}
\hline \multirow{2}{*}{\multicolumn{2}{|c|}{ Type of Chemical Compound }} & \multicolumn{2}{|c|}{ Structure } & \multirow{2}{*}{ Compound Cations } \\
\hline & & Structural Type & Syngony, Sp. gr. & \\
\hline \multirow{11}{*}{ Phosphates } & $\mathrm{NaAlSiO}_{4}$ & Nepheline/Leucite & $\begin{array}{c}\text { Nepheline: hexagonal, } \\
\text { P6 } 6_{3} ; \\
\text { Leucite: tetragonal, I4 } 4_{1} / \mathrm{a}, \\
\text { I4 }_{1} / \text { acd; cubic, Ia3d }\end{array}$ & $\begin{array}{l}\mathrm{Li}, \mathrm{Na}, \mathrm{K}, \mathrm{Rb}, \mathrm{Cs}, \mathrm{Be}, \mathrm{Mg}, \mathrm{Ca}, \mathrm{Ba}, \mathrm{Pb}, \\
\quad \mathrm{Mn}, \mathrm{Co}, \mathrm{Ni}, \mathrm{Al}, \mathrm{Fe}, \mathrm{Cr}, \mathrm{Si}, \mathrm{Ti}, \mathrm{V}\end{array}$ \\
\hline & $\mathrm{Na}_{8} \mathrm{Cl}_{2} \mathrm{Al}_{6} \mathrm{Si}_{6} \mathrm{O}_{24}$ & Sodalite & cubic, $P_{\overline{4}} 3 n$ & $\begin{array}{c}\mathrm{Na}, \mathrm{K}, \mathrm{Mg}, \mathrm{Ca}, \mathrm{Mn}, \mathrm{Fe}, \mathrm{Al}, \mathrm{Si}, \mathrm{Ti}, \mathrm{Cl} \text {, } \\
\mathrm{SO}_{4}, \mathrm{CO}_{3}\end{array}$ \\
\hline & $(\mathrm{Na}, \mathrm{Ca}, \mathrm{K})_{6}\left[\mathrm{Al}_{6} \mathrm{Si}_{6} \mathrm{O}_{24}\right]\left((\mathrm{Na}, \mathrm{Ca}, \mathrm{K})_{2} \mathrm{CO}_{3}\right)_{1.6} \cdot 2.1 \mathrm{H}_{2} \mathrm{O}$ & Cancrinite & $\begin{array}{l}\text { hexagonal, } \mathrm{P}_{3} \\
\text { cubic, sp. gr. } \mathrm{Pm} 3 \mathrm{~m} \text { up to }\end{array}$ & $\mathrm{Cl}^{-}, \mathrm{SO}_{4}^{2-}$ \\
\hline & {$\left[(\mathrm{Ca}, \mathrm{Na}, \mathrm{K}, \mathrm{Ba}) \mathrm{AlSiO}_{4}\right.$} & $\begin{array}{l}\text { Crystalline SilicoTitanate } \\
\text { (CST) }\end{array}$ & $\begin{array}{l}105^{\circ} \mathrm{C} \text {, after tetragon. } \\
\text { symm., sp. gr. I4/mcm or } \\
\mathrm{P} 4_{2} / \mathrm{mcm}\end{array}$ & $\begin{array}{c}\mathrm{Na}, \mathrm{K}, \mathrm{Cs}, \mathrm{Ca}, \mathrm{Sr}, \mathrm{Ba}, \mathrm{Pb}, \mathrm{Al}, \mathrm{REE}, \mathrm{Bi}, \\
\mathrm{Ti}, \mathrm{Zr}, \mathrm{Nb}, \mathrm{Ta}\end{array}$ \\
\hline & $\begin{array}{c}\mathrm{LiAl}_{3} \mathrm{Si}_{3} \mathrm{O}_{11}, \mathrm{NaAl}_{3} \mathrm{Si}_{3} \mathrm{O}_{11}, \mathrm{KAl}_{3} \mathrm{Si}_{3} \mathrm{O}_{11}, \mathrm{RbAl}_{3} \mathrm{Si}_{3} \mathrm{O}_{11}, \mathrm{CsAl}_{3} \mathrm{Si}_{3} \mathrm{O}_{11} \\
\mathrm{TlAl}_{3} \mathrm{Si}_{3} \mathrm{O}_{11}, \mathrm{Ca}_{0.5} \square_{0.5} \mathrm{Al}_{3} \mathrm{Si}_{3} \mathrm{O}_{11}, \mathrm{Sr}_{0.5} \square_{0.5} \mathrm{Al}_{3} \mathrm{Si}_{3} \mathrm{O}_{11}, \mathrm{Ba}_{0.5} \square_{0.5} \mathrm{Al}_{3} \mathrm{Si}_{3} \mathrm{O}_{11}\end{array}$ & Micas (Dehydroxylated) & monoclinic, $\mathrm{C} 2 / \mathrm{c}$ & $\begin{array}{c}\mathrm{Cs}, \mathrm{Rb}, \mathrm{Ba}, \mathrm{Mg}, \mathrm{Fe}^{2+}, \mathrm{Fe}^{3+}, \mathrm{Mn}, \mathrm{Li}, \mathrm{Cr}, \\
\mathrm{Ti}, \mathrm{V}\end{array}$ \\
\hline & 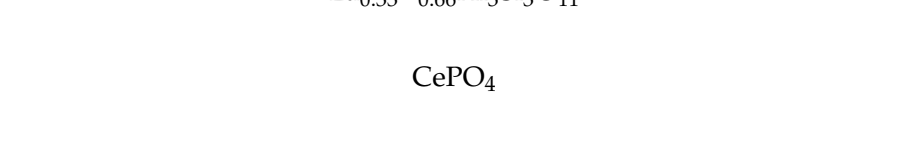 & Monazite & monoclinic, $\mathrm{P} 21 / \mathrm{n}$ & $\begin{array}{c}\text { Ce: } \mathrm{Li}, \mathrm{Na}, \mathrm{K}, \mathrm{Rb}, \mathrm{Mg}, \mathrm{Ca}, \mathrm{Sr}, \mathrm{Ba}, \mathrm{Cd}, \\
\mathrm{Pb}, \mathrm{Bi}, \mathrm{Y}, \mathrm{La}, \mathrm{Pr}, \mathrm{Nd}, \mathrm{Sm}, \mathrm{Eu}, \mathrm{Gd}, \mathrm{Tb} \\
\mathrm{Yb}, \mathrm{Am}, \mathrm{Cm}, \mathrm{Cf}, \mathrm{Es}, \mathrm{Ge}, \mathrm{Zr}, \mathrm{Th}, \mathrm{Np}, \mathrm{U}, \\
\mathrm{Pu} ; \mathrm{P}: \mathrm{Cr}, \mathrm{Si}, \mathrm{Se}, \mathrm{V}, \mathrm{As}, \mathrm{S}\end{array}$ \\
\hline & $\mathrm{YPO}_{4}$ & Xenotime & tetragonal, $\mathrm{I}_{1} / \mathrm{amd}$ & $\begin{array}{c}\mathrm{Be}, \mathrm{Ca}, \mathrm{Al}, \mathrm{Sc}, \mathrm{La}, \mathrm{Ce}, \mathrm{Er}, \mathrm{Dy}-\mathrm{Lu}, \mathrm{Zr}, \\
\text { Th, U }\end{array}$ \\
\hline & $\mathrm{Ca}_{4-\mathrm{x}} \mathrm{RE}_{6+\mathrm{x}}\left(\mathrm{SiO}_{4}\right)_{6-\mathrm{y}}\left(\mathrm{PO}_{4}\right)_{\mathrm{y}}(\mathrm{O}, \mathrm{F})_{2}$ & Apatite & $\begin{array}{l}\text { hexagonal, } \mathrm{P} 6_{3} / \mathrm{m} ; \\
\text { monoclinic, } \mathrm{P} 2_{1} / \mathrm{b}\end{array}$ & $\begin{array}{c}\mathrm{Na}, \mathrm{K}, \mathrm{Cs}, \mathrm{Mg}, \mathrm{Ca}, \mathrm{Sr}, \mathrm{Ba}, \mathrm{Mn}, \mathrm{Ni}, \mathrm{Cd}, \\
\mathrm{Hg}, \mathrm{Pb}, \mathrm{Cr}, \mathrm{Y}, \mathrm{REE}, \mathrm{Th}, \mathrm{U}, \mathrm{Si}, \mathrm{P}, \mathrm{V}, \mathrm{As}, \\
\text { S, F, Cl, OH, CO } \\
\mathrm{Li}, \mathrm{Na}, \mathrm{K}, \mathrm{Rb}, \mathrm{Cs} ; \mathrm{H}, \mathrm{Cu}(\mathrm{I}), \mathrm{Ag}, \mathrm{Mg},\end{array}$ \\
\hline & $\mathrm{NaZr}_{2}\left(\mathrm{PO}_{4}\right)_{3}$ & $\begin{array}{l}\text { Sodium zirconium } \\
\text { phosphate (NZP) }\end{array}$ & $\begin{array}{l}\text { rhombohedral, } R \overline{3} c, R 3 c, \\
\text { R3 }\end{array}$ & $\begin{array}{c}\mathrm{Ca}, \mathrm{Sr}, \mathrm{Ba}, \mathrm{Mn}, \mathrm{Co}, \mathrm{Ni}, \mathrm{Cu}, \mathrm{Zn}, \mathrm{Cd}, \\
\mathrm{Hg}, \mathrm{Al}, \mathrm{Ga}, \mathrm{In}, \mathrm{Sc}, \mathrm{Y}, \mathrm{La}, \mathrm{Ce}-\mathrm{Lu}, \mathrm{Am}, \\
\mathrm{Cm}, \mathrm{V}, \mathrm{Cr}, \mathrm{Fe}, \mathrm{Sb}, \mathrm{Bi}, \mathrm{Ge}, \mathrm{Sn}, \mathrm{Ti}, \mathrm{Zr}, \mathrm{Hf}, \\
\mathrm{Mo}, \mathrm{Ce}, \mathrm{Th}, \mathrm{U}, \mathrm{Np}, \mathrm{Pu}, \mathrm{Sb}, \mathrm{Nb}, \mathrm{Ta}\end{array}$ \\
\hline & $\mathrm{K}_{2} \mathrm{Mg}_{2}\left(\mathrm{SO}_{4}\right)_{3}$ & Langbeinite & cubic, $\mathrm{P} 2{ }_{1} 3$ & $\begin{array}{c}\mathrm{Na}, \mathrm{K}, \mathrm{Rb}, \mathrm{Cs}, \mathrm{Tl}, \mathrm{NH} 4, \mathrm{Mg}, \mathrm{Sr}, \mathrm{Ba}, \mathrm{Pb}, \\
\mathrm{Mn}, \mathrm{Co}, \mathrm{Ni}, \mathrm{Zn}, \mathrm{Al}, \mathrm{Fe} \mathrm{Cr}, \mathrm{Ti}^{3+}, \mathrm{Ga}, \\
\mathrm{V}^{3+}, \mathrm{Rh}, \mathrm{In}, \mathrm{REE}, \mathrm{Bi}, \mathrm{Sn}, \mathrm{Ti}, \mathrm{Zr}, \mathrm{Hf}, \mathrm{P}, \\
\mathrm{Nb}, \mathrm{Ta}, \mathrm{S}\end{array}$ \\
\hline & $\beta-\mathrm{Ca}_{3}\left(\mathrm{PO}_{4}\right)_{2}$ & Whitlockite & trigonal, R3c & $\begin{array}{c}\mathrm{H}, \mathrm{Li}, \mathrm{Na}, \mathrm{K}, \mathrm{Cu}, \mathrm{Mg}, \mathrm{Ca}, \mathrm{Sr}, \mathrm{Ba}, \mathrm{Al} \text {, } \\
\mathrm{Sc}, \mathrm{Cr}, \mathrm{Fe}, \mathrm{Ga}, \mathrm{In}, \mathrm{La}, \mathrm{Ce}, \mathrm{Sm}, \mathrm{Eu}, \mathrm{Gd} \text {, } \\
\mathrm{Lu}, \mathrm{Th}, \mathrm{Pu}\end{array}$ \\
\hline
\end{tabular}


Table 1. Crystalline ceramic materials as potential forms for nuclear waste immobilization.

\begin{tabular}{|c|c|c|c|c|}
\hline & \multirow{2}{*}{ Type of Chemical Compound } & \multicolumn{2}{|c|}{ Structure } & \multirow{2}{*}{ Compound Cations } \\
\hline & & Structural Type & Syngony, Sp. gr. & \\
\hline & $\mathrm{Th}_{4}\left(\mathrm{PO}_{4}\right)_{4} \mathrm{P}_{2} \mathrm{O}_{7}$ & $\begin{array}{c}\text { Thorium } \\
\text { phosphate/Diphosphate } \\
\text { (TPD) }\end{array}$ & $\begin{array}{l}\text { orthorhombic, } \mathrm{Pbcm} \text {, } \\
\text { Pcam }\end{array}$ & \multirow{3}{*}{$\begin{array}{c}\mathrm{U}, \mathrm{Np}, \mathrm{Pu}, \mathrm{Am}, \mathrm{Cm} \\
\mathrm{Ca}: \mathrm{Li}, \mathrm{Na}, \mathrm{K}, \mathrm{Rb}, \mathrm{Cs}, \mathrm{Tl} ; \mathrm{Ca}, \mathrm{Sr}, \mathrm{Ba}, \\
\mathrm{Mn}, \mathrm{Cu} ; \mathrm{Fe}, \mathrm{Ce}, \mathrm{La}-\mathrm{Lu}, \mathrm{Y} ; \mathrm{Th}, \mathrm{U}, \mathrm{Np}, \\
\mathrm{Pu} \text {, Nb, Ta; } \mathrm{W}: \mathrm{Mo}, \mathrm{Re}, \mathrm{I}, \mathrm{V}, \mathrm{Ge} \\
\mathrm{Na}, \mathrm{Cs}, \mathrm{Mg}, \mathrm{Sr}, \mathrm{Ba}, \mathrm{Pb}, \mathrm{Mn}, \mathrm{Co}, \mathrm{Cu}, \\
\mathrm{Al}, \mathrm{Fe}, \mathrm{Sc}, \mathrm{Y}, \mathrm{La}, \mathrm{Ce}, \mathrm{Sm}, \mathrm{Gd}, \mathrm{Yb}, \mathrm{Lu}, \\
\mathrm{An}, \mathrm{Si}, \mathrm{Ti}, \mathrm{Sn}\end{array}$} \\
\hline Tungstates & $\mathrm{CaWO}_{4}$ & Scheelite & tetragonal, I4/c & \\
\hline Aluminates & $\mathrm{X}(\mathrm{Al}, \mathrm{Fe})_{12} \mathrm{O}_{19}$ & Magnetoplumbite & hexagonal, $\mathrm{P} 6_{3} / \mathrm{mmc}$ & \\
\hline
\end{tabular}


Many of the compounds listed here have been studied and continue to be actively investigated by researchers led by the co-author of this work (Prof Orlova), including those with structures of garnet [185,189-194], P-pollucite [205-215], pollucite [214,215,293], monazite [141,352], sodium zirconium phosphate (NZP) [21,209,383,384,388,392-394,396,405,407-409,412-419], langbeinite [416-419], whitlockite $[87,89,424-430]$ and scheelite $[89,445,446]$. Overall crystalline ceramics are characterized as much more durable compared with glasses of the same chemical composition e.g., the chemical durability of isomorph glasses is one to two orders of magnitude lower [458-460]. Nevertheless, the degree of the development of crystalline ceramics remains at the level of laboratory investigations rather than industrial use, except for SYNROC polyphase crystalline ceramic that is at the stage of the planned start of utilization by industry. Practically all structural forms developed (Table 1) are at the stage of obtaining compounds and their studies at the laboratory scale. The references $[15,458-460]$ are also providing data on the acceptability of ionic size variability within the structure, and on chemical and radiation durability.

From the analysis of the presented data of various compounds with various compositions and structural forms it is clear that researchers in the field of materials for nuclear waste immobilization have many variants available for work. While materials are mineral-like the principle "from nature to nature" can be realized. Although many structures were included herewith, some could be missed, for example brannerite [15,99], which is currently considered for actinide immobilization [461]. Among most investigated structures one can note oxide ceramics. Some of crystalline ceramics such as monazite were synthesized using real (radioactive) actinides [15,235], whereas most of researchers use surrogate (non-radioactive) cations for investigations.

\section{Conclusions}

1. Ceramic waste-forms for nuclear waste immobilization are investigated in different countries with a focus on improving environmental safety during storage, transport and disposal.

2. Inorganic compounds of oxide and salt character, having structural analogs with natural minerals, are being studied as most perspective materials for the immobilization of radioactive waste.

3. Approaches based on crystallochemistry principles are used when choosing the most favorable structural forms. They are based on the materials science concept "composition-structure-method of synthesis-property" accounting for the real task to be achieved. The basic principle is the isomorphism of cations and anions in compounds when choosing a real structure. Possible isomorphic substitutions in both cationic and anionic structural sites were considered in the works analyzed.

4. Crystalline ceramic waste-forms are intended to increase the environmental safety barrier when isolating radioactive materials (containing both actinides and fission products) from the biosphere. Among the methods of obtaining ceramic waste-forms, special attention in recent years is paid to sintering methods which ensure the formation of ceramics that, first, are almost non-porous e.g., have a relative density of up to $99.0-99.9 \%$ of theoretical, and, second, can be obtained within a small processing time e.g., within a few minutes (i.e., $2-3 \mathrm{~min}$ ). These requirements are met by high-speed electric pulse sintering processes e.g., so-called Spark Plasma Sintering (SPS), although hot pressing enables the synthesis of very dense ceramics as well.

Professor Albina Orlova is working in the field of new inorganic materials used in nuclear chemistry for the rad-waste immobilization of dangerous isotopes, for actinide transmutation, as well for construction materials. She uses the structure properties and physico-chemical principles for the elaboration of new ceramics with mineral-like crystal forms.

Professor Michael Ojovan is known for the connectivity-percolation theory of glass transition, the Sheffield model (two-exponential equation) of viscosity of glasses and melts, condensed Rydberg matter, metallic and glass-composite materials for nuclear waste immobilization, and self-sinking capsules to investigate Earth's deep interior. 
Author Contributions: A.I.O. conceived the study, both A.I.O. and M.I.O. equally contributed to final paper preparation.

Funding: This research was funded by Russian Science Foundation grant number RSF-16-13-10464 (Scientific Supervisor A.I. Orlova).

Conflicts of Interest: The authors declare no conflict of interest.

\section{References}

1. Hatch, L.P. Ultimate Disposal of Radioactive Wastes. Am. Sci. 1953, 41, 410-421.

2. McCarthy, G.J. Quartz-Matrix Isolation of Radioactive Wastes. J. Mater. Sci. 1973, 8, 1358-1359. [CrossRef]

3. McCarthy, G.J.; Davidson, M.T. Ceramic Nuclear Waste Forms: I. Crystal Chemistry and Phase Formation. Bull. Am. Ceram. Soc. 1975, 54, 782-786.

4. Roy, R. Rationale Molecular Engineering of Ceramic Materials. J. Am. Ceram. Soc. 1977, 60, 350-363. [CrossRef]

5. Jantzen, C.M.; Lee, W.E.; Ojovan, M.I. Radioactive waste (RAW) conditioning, immobilization, and encapsulation processes and technologies: overview and advances. In Radioactive Waste Management and Contaminated Site Clean-Up. Processes, Technologies and International Experience; Lee, W.E., Ojovan, M.I., Jantzen, C.M., Eds.; Woodhead Published Limited: Oxford, UK; Cambridge, UK; Philadelphia, PA, USA; New Delhi, India, 2013; Chapter 6; pp. 171-272.

6. Schoebel, R.O. Stabilization of High Level Waste in Ceramic Form. Bull. Am. Ceram. Soc. 1975, 54, 459.

7. Ringwood, A.E.; Oversby, V.M.; Kesson, S.E. SYNROC: Leaching Peformance and Process Technology. In Proceedings of the Seminar on Chemistry and Process Engineering for High Level Liquid Waste Solidification, Jülichw, Germany, 1-5 June 1981; pp. 495-506.

8. Ringwood, A.E. Safe Disposal of High Level Nuclear Reactor Wastes: A New Strategy; Australian Nuclear University Press: Canberra, Australia, 1978; pp. 1-64.

9. Ringwood, A.E.; Kesson, S.E.; Ware, N.G.; Hibberson, W.O.; Major, A. The SYNROC Process: A Geochemical Approach to Nuclear Waste Immobilization. Geochem. J. 1979, 13, 141-165. [CrossRef]

10. Vance, E.R.; Moricca, S.A.; Stewart, M.W.A. Progress at ANSTO on a synroc plant for intermediate-level waste from reactor production of ${ }^{99}$ Mo. Adv. Sci. Technol. 2014, 94, 111-114. [CrossRef]

11. McCarthy, G.J.; Pepin, J.G.; Pfoertsch, D.E.; Clarke, D.R. Crystal Chemistry of the Synthetic Minerals in Current Supercalcine-Ceramics; U.S. DOE Report CONF-790420; Battelle Pacific Northwest Labs.: Richland, WA, USA, 1979; pp. 315-320.

12. Lutze, W.; Ewing, R.C. Radioactive Waste Forms for the Future; North-Holland Publishers: Amsterdam, The Netherlands, 1988; p. 778.

13. Jantzen, C.M.; Flintoff, J.; Morgan, P.E.D.; Harker, A.B.; Clarke, D.R. Ceramic Nuclear Waste Forms. In Proceedings of the Seminar on Chemistry and Process Engineering for High-Level Liquid Waste Solidification, Jülichw, Germany, 1-5 June 1981; Volume 2, pp. 693-706.

14. Raison, P.E.; Haire, R.G.; Sato, T.; Ogawa, T. Fundamental and Technological Aspects of Actinide Oxide Pyrochlores: Relevance for Immobilization Matrices; MRS Online Proceedings Library Archive: Warrendale, PA, USA, 1999; p. 556.

15. Burakov, B.E.; Ojovan, M.I.; Lee, W.E. Crystalline Materials for Actinide Immobilization; Imperial College Press: London, UK, 2010.

16. Dacheux, N.; Clavier, N.; Podor, R. Monazite as a promising long-term radioactive waste matrix: Benefits of high-structural flexibility and chemical durability. Am. Miner. 2013, 98, 833-847. [CrossRef]

17. Clavier, N.; Podor, R.; Dacheux, N. Crystal chemistry of the monazite structure. J. Eur. Ceram. Soc. 2011, 31, 941-976. [CrossRef]

18. Orlova, A.I.; Lizin, A.A.; Tomilin, S.V.; Lukinykh, A.N. On the Possibility of Realization of Monazite and Langbeinite Structural Types in Complex Americium and Plutonium Phosphates. Synthesis and X-ray Diffraction Studies. Radiochemistry 2011, 53, 63-68. [CrossRef]

19. Alamo, J.; Roy, R. Revision of Crystalline Phases in the System $\mathrm{ZrO}_{2}-\mathrm{P}_{2} \mathrm{O}_{5}$. Commun. Am. Ceram. Soc. 1984, 67, C80-C82. [CrossRef] 
20. Hawkins, H.T.; Spearing, D.R.; Veirs, D.K.; Danis, J.A.; Smith, D.M.; Tait, C.D.; Runde, W.H. Synthesis and Characterization of Uranium(IV)-Bearing Members of the [NZP] Structural Family. Chem. Mater. 1999, 11, 2851-2857. [CrossRef]

21. Orlova, A.I. Isomorphism in Crystalline Phosphates of the $\mathrm{NaZr}_{2}\left(\mathrm{PO}_{4}\right)_{3}$ structural type and Radiochemical Problems. Radiochemistry 2002, 44, 423-445. [CrossRef]

22. Volkov, Y.F.; Tomlin, S.V.; Orlova, A.I.; Lizin, A.A.; Spirjakov, V.I.; Lukinikh, A.N. Actinide Phosphates $\mathrm{A}^{\mathrm{I}} \mathrm{M}_{2}{ }^{\mathrm{IV}}(\mathrm{PO} 4)_{3}(\mathrm{MIV}=\mathrm{U}, \mathrm{Np}, \mathrm{Pu} ; \mathrm{AI}=\mathrm{Na}, \mathrm{K}, \mathrm{Rb})$ with rombohedral structure. Radiochemistry 2003, 46, 319-328. [CrossRef]

23. Gregg, D.J.; Karatchevtseva, I.; Triani, G.; Lumpkin, G.R.; Vance, E.R. The thermophysical properties of calcium and barium zirconium phosphate. J. Nucl. Mater. 2013, 441, 203-210. [CrossRef]

24. Gregg, D.J.; Karatchevtseva, I.; Thorogood, G.J.; Davis, J.; Bell, B.; Jackson, M.; Dayal, P.; Ionescu, M.; Triani, G.; Short, K.; et al. Ion Beam Irradiation Effects in Strontium Zirconium Phosphate with NZP-structure type. J. Nucl. Mater. 2014, 446, 224-231. [CrossRef]

25. Orlova, A.I.; Koryttseva, A.K.; Loginova, E.E. A Family of Phosphates of Langbeinite Structure. Crystal-Chemical Aspect of Radioactive Waste Immobilization. Radiochemistry 2011, 53, 51-62. [CrossRef]

26. Orlova, A.I. Chemistry and structural chemistry of anhydrous tri- and tetravalent actinide orthophosphates. In Structural Chemistry of Inorganic Actinide Compounds; Chapter 8; Krivovichev, S.V., Burns, P.C., Tananaev, I.G., Eds.; Elsevier: Amsterdam, The Netherlands, 2007; pp. 315-340.

27. Huittinen, N.; Scheinost, A.C.; Ji, Y.; Kowalski, P.M.; Arinicheva, Y.; Wilden, A.; Neumeier, S.; Stumpf, T. A spectroscopic and computational study of $\mathrm{Cm}^{3+}$ incorporation in lanthanide phosphate rhabdophane $\left(\mathrm{LnPO}_{4} \cdot 0.67 \mathrm{H}_{2} \mathrm{O}\right)$ and monazite $\left(\mathrm{LnPO}_{4}\right)$. Inorg. Chem. 2018, 57, 6252-6265. [CrossRef]

28. Clarke, D.R. Preferential Dissolution of an Intergranular Amorphous Phase in a Nuclear Waste Ceramic. J. Am. Ceram. Soc. 1981, 64, 89-90. [CrossRef]

29. Cooper, J.A.; Cousens, D.R.; Hanna, J.A.; Lewis, R.A.; Myhra, S.; Segall, R.L.; Smart, R.S.C.; Turner, P.S.; White, T.J. Intergranular Films and Pore Surfaces in Synroc C: Structure, Composition, and Dissolution characteristics. J. Am. Ceram. Soc. 1986, 69, 347-352. [CrossRef]

30. Buykx, W.J.; Hawkins, K.; Levins, D.M.; Mitamura, H.; Smart, R.S.C.; Stevens, G.T.; Watson, K.G.; Weedon, D.; White, T.J. Titanate Ceramics for the Immobilization of SodiumBearing High-Level Nuclear Waste. J. Am. Ceram. Soc. 1988, 71, 768-788. [CrossRef]

31. Dickson, F.J.; Mitamura, H.; White, T.J. Radiophase Development in Hot-Pressed Alkoxide-Derived Titanate Ceramics for Nuclear Waste Stabilization. J. Am. Ceram. Soc. 1989, 72, 1055-1059. [CrossRef]

32. Buykx, W.J.; Levins, D.M.; Smart, R.S.C.; Smith, K.L.; Stevens, G.T.; Watson, K.G.; Weedon, D.; White, T.J. Interdependence of Phase Chemistry, Microstructure, and Oxygen Fugacity in Titanate Nuclear Waste Ceramics. J. Am. Ceram. Soc. 1990, 73, 1201-1207. [CrossRef]

33. Buykx, W.J.; Levins, D.M.; St Smart, R.C.; Smith, K.L.; Stevens, G.T.; Watson, K.G.; White, T.J. Processing Impurities as Phase Assemblage Modifiers in Titanate Nuclear Waste Ceramics. J. Am. Ceram. Soc. 1990, 73, 217-225. [CrossRef]

34. Mitamura, H.; Matsumoto, S.; Hart, K.P.; Miyazaki, T.; Vance, E.R.; Tamura, Y.; Togashi, Y.; White, T.J. Aging Effects on Curium-Dopped Titantate Ceramics Containing Sodium-Bearing High-Level Nuclear Waste. J. Am. Ceram. Soc. 1992, 75, 392-400. [CrossRef]

35. Zhang, Z.; Carter, M.L. An X-Ray Photoelectron Spectroscopy Investigation of Highly Soluble Grain-Boundary Impurity Films in Hollandite. J. Am. Ceram. Soc. 2010, 93, 894-899. [CrossRef]

36. Harker, A.B.; Clarke, D.R.; Jantzen, C.M.; Morgan, P.E.D. The Effect of Interfacial Material on Tailored Ceramic Nuclear Waste Form Dissolution, Surfaces and Interfaces in Ceramic and Ceramic-Metal Systems; Pask, J., Evans, A., Eds.; Plenum Press: New York, NY, USA, 1981; Volume 14, pp. 207-216.

37. Roy, R. Hydroxylated Ceramic Waste Forms and the Absurdity of Leach Tests. In Proceedings of the International Seminar on Chemistry and Process Engineering for High-Level Liquid Waste Solidification, Julich, India, 1-5 June 1981; pp. 576-602.

38. Mason, J.B.; Oliver, T.W.; Carson, M.P.; Hill, G.M. Studsvik Processing Facility Pyrolysis/Steam Reforming Technology for Volume and Weight Reduction and Stabilization of LLRW and Mixed Wastes; American Institute of Chemical Engineers: New York, NY, USA, 1999.

39. Mason, J.B.; McKibbin, J.; Ryan, K.; Schmoker, D. Steam Reforming Technology for Denitration and Immobilization of DOE Tank Wastes; THOR Treatment Technologies, LLC.: Richland, WA, USA, 2003. 
40. Jantzen, C.M.; Lorier, T.H.; Marra, J.C.; Pareizs, J.M. Durability Testing of Fluidized Bed Steam Reforming (FBSR) Waste Forms WM06 Paper № 6373; WWM Symposia: Phoenix, AZ, USA, 2006.

41. Jantzen, C.M.; Lorier, T.H.; Pareizs, J.M.; Marra, J.C. Fluidized Bed Steam Reformed (FBSR) Mineral Waste Forms: Characterization and Durability Testing; MRS Online Proceedings Library Archive: Warrendale, PA, USA, 2007; pp. 379-386.

42. Jantzen, C.M. Mineralization of Radioactive Wastes By Fluidized Bed Steam Reforming (FBSR): Comparisons to Vitreous Waste Forms and Pertinent Durability Testing; U.S. DOE Report WSRC-STI-2008-00268; Westinghouse Savannah River Company, Savannah River Site: Aiken, SC, USA, 2008.

43. Jantzen, C.M.; Crawford, C.L.; Burket, P.B.; Daniel, W.G.; Cozzi, A.D.; Bannochie, C.J. Radioactive Demonstrations of Fluidized Bed Steam Reforming (FBSR) as a Supplementary Treatment for Hanford's Low Activity Waste (LAW) and Secondary Wastes (SW); Waste Management WM11, Paper № 11593; WM Symposia: Phoenix, AZ, USA, 2011.

44. Jantzen, C.M.; Crawford, C.L.; Burket, P.R.; Bannochie, C.J.; Daniel, W.G.; Nash, C.A.; Cozzi, A.D.; Herman, C.C. Radioactive Demonstrations of Fluidized Bed Steam Reforming (FBSR) with Actual Hanford Low Activity Wastes: Verifying FBSR as a Supplemental Treatment; WM12 Paper № 12317; WM Symposia: Phoenix, AZ, USA, 2012.

45. Jantzen, C.M.; Glasser, F.P. Crystallochemical Stabilization of Radwaste Elements in Portland Cement Clinker. In Proceedings of the International Symposium on Ceramics in Nuclear Waste Management; CONF-790420, Cincinnati, OH, USA, 30 April-2 May 1979; pp. 342-348.

46. Jantzen, C.M.; Glasser, F.P. Stabilization of Nuclear Waste Constituents in Portland Cement. Am. Ceram. Soc. Bull. 1979, 58, 459-466.

47. Bragg, L.; Claringbull, G.F.; Taylor, W.H. Crystal Structures of Minerals; G. Bell \& Sons: London, UK, 1965; p. 409.

48. Shannon, R.D.; Prewitt, C.T. Effective Ionic Radii in Oxides and Fluorides. Acta Cryst. 1969, B25, 925-946. [CrossRef]

49. Shannon, R.D.; Prewitt, C.T. Revised Values of Effective Ionic Radii. Acta Cryst. 1970, B26, $1046-1048$. [CrossRef]

50. Shannon, R.D. Revised Effective Ionic Radii and Systematic Studies of Interatomic Distances in Halides and Chalcogenides. Acta Cryst. 1976, A32, 751-767. [CrossRef]

51. Felsche, J. Rare Earth Silicates with the Apatite Structure. J. Solid State Chem. 1972, 5, 266-275. [CrossRef]

52. Jantzen, C.M.; Glasser, F.P.; Lachowsli, E.E. Radioactive Waste-Portland Cement Systems: I. Radionuclide Distribution. J. Am. Ceram. Soc. 1984, 67, 668-673. [CrossRef]

53. Jantzen, C.M.; Glasser, F.P.; Lachowsli, E.E. Radioactive Waste-Portland Cement Systems: II. Leaching Characteristics. J. Am. Ceram. Soc. 1984, 67, 674-678. [CrossRef]

54. Ringwood, A.E.; Kesson, S.E. Immobilization of High-Level Wastes in Synroc Titanate Ceramic. In Proceedings of the International Symposium on Ceramics in Nuclear WaMc Management, CONF-790420, Cincinnati, OH, USA, 30 April-2 May 1979; pp. 174-178.

55. Cooper, J.A.; Cousens, D.R.; Lewis, R.A.; Myhra, S.; Segall, R.L.; Smart, R.S.C.; Turner, P.S.; White, T.J. Microstructural Characterization of Synroc C and E by Electron Microscopy. J. Am. Ceram. Soc. 1985, 68, 64-70. [CrossRef]

56. Aubin, V.; Caurant, D.; Gourier, D.; Baffier, N.; Advocat, F.; Bart, F.; Leturcq, G.; Costantini, J.M. Synthesis, Characterization and Study of the Radiation Effects on Hollandite Ceramics Developed for Cesium Immobilization. Mater. Res. Soc. Symp. Proc. 2004, 807, 315-320. [CrossRef]

57. Hart, K.P.; Vance, E.R.; Day, R.A.; Begg, B.D.; Angel, P.J. Immobilization of Separated Tc and Cs/Sr in SYNROC. Mater. Res. Soc. Symp. Proc. 1996, 412, 281-287. [CrossRef]

58. Buerger, M.J.; Klein, G.E.; Hamburger, G.E. Structure of Nepheline. Geol. Soc. Am. Bull. 1946, 57, $1182-1183$.

59. Buerger, M.J.; Klein, G.E.; Hamburger, G.E. The structure of nepheline. Am. Mineral. 1947, 32, 197.

60. Simmons, W.B.; Peacor, D.R. Refinement of the crystal structure of a volcanic nepheline. Am. Mineral. 1972, $57,1711-1719$.

61. Rossi, G.; Oberti, R.; Smith, D.C. The crystal structure of a K-poor Ca-rich silicate with the nepheline framework, and crystal-chemical relationships in the compositional space $\left(\mathrm{K}, \mathrm{Na}, \mathrm{Ca},{ }_{2}{ }_{8}(\mathrm{Al}, \mathrm{Si})_{16} \mathrm{O}_{32}\right.$. Eur. J. Mineral. 1989, 1, 59-70. [CrossRef] 
62. Tait, K.T.; Sokolova, E.V.; Hawthorne, F.C.; Khomyakov, A.P. The crystal chemistry of nepheline. Can. Mineral. 2003, 41, 61-70. [CrossRef]

63. Hassan, I.; Antao, S.M.; Hersi, A.A.M. Single-crystal XRD, TEM, and thermal studies of the satellite reflections in nepheline. Can. Mineral. 2003, 41, 759-783. [CrossRef]

64. Gatta, G.D.; Angel, R.J. Elastic behavior and pressure-induced structural evolution of nepheline: Implications for the nature of the modulated superstructure. Am. Mineral. 2007, 92, 1446-1455. [CrossRef]

65. Angel, R.J.; Gatta, G.C.; Ballaran, T.B.; Carpenter, M.A. The mechanism of coupling in the modulated structure of nepheline. Can. Mineral. 2008, 46, 1465-1476. [CrossRef]

66. Antao, S.M.; Nepheline, H.I. Structure of three samples from the Bancroft area, Ontario,obtained using synchrotron high-resolution powder x-ray diffraction. Can. Mineral. 2010, 48, 69-80. [CrossRef]

67. Chapman, K.W.; Chupas, P.J.; Nenoff, T.M. Radioactive Iodine Capture in Silver-Containing Mordenites through Nanoscale Silver Iodide Formation. J. Am. Chem. Soc. 2010, 132, 8897-8899. [CrossRef]

68. Matyas, J.; Fryxell, G.; Busche, B.; Wallace, K.; Fifield, L. Functionalised silica aerogels: Advanced materials to capture and immobilise radioactive iodine. In Ceramic Engineering and Science Proceedings; American Ceramic Society, Inc.: Columbus, OH, USA, 2011; pp. 23-32.

69. Riley, B.J.; Chun, J.; Ryan, J.V.; Matyáš, J.; Li, X.S.; Matson, D.W.; Sundaram, S.K.; Strachan, D.M.; Vienna, J.D. Chalcogen-based aerogels as a multifunctional platform for remediation of radioactive iodine. RSC Adv. 2011, 1, 1704-1715. [CrossRef]

70. Yang, J.H.; Cho, Y.-J.; Shin, J.M.; Yim, M.-S. Bismuth-embedded SBA-15 mesoporous silica for radioactive iodine capture and stable storage. J. Nucl. Mater. 2015, 465, 556-564. [CrossRef]

71. Subrahmanyam, K.S.; Sarma, D.; Malliakas, C.D.; Polychronopoulou, K.; Riley, B.J.; Pierce, D.A.; Chun, J.; Kanatzidis, M.G. Chalcogenide Aerogels as Sorbents for Radioactive Iodine. Chem. Mater. 2015, 27, 2619-2626. [CrossRef]

72. Matyas, J.; Canfield, N.; Silaiman, S.; Zumhoff, M. Silica-based waste form for immobilization of iodine from reprocessing plant off-gas streams. J. Nucl. Mater. 2016, 476, 255-261. [CrossRef]

73. Vienna, J.D.; Kroll, J.O.; Hrma, P.R.; Lang, J.B.; Crum, J.V. Submixture Model to Predict Nepheline Precipitation in Waste Glasses. Int. J. Appl. Glass Sci. 2017, 8, 143-157. [CrossRef]

74. Asmussen, R.M.; Matyáš, J.; Qafoku, N.P.; Kruger, A.A. Silver-functionalized silica aerogels and their application in the removal of iodine from aqueous environments. J. Hazard. Mater. 2018. [CrossRef]

75. Asmussen, R.M.; Ryan, J.V.; Matyas, J.; Crum, J.V.; Reiser, J.T.; Avalos, N.; McElroy, E.M.; Lawter, A.R.; Canfield, N.C. Investigating the Durability of Iodine Waste Forms in Dilute Conditions. Materials 2019, 12, 686. [CrossRef]

76. Burghatz, M.; Matzke, H.; Leger, C.; Vambenepe, G.; Rome, M. Inert Matrices for the Transmuation of Actinides; Fabrication, Thermal Properties and Radiation Stability of Ceramic Materials. J. Nucl. Mater. 1998, 271, 544-548.

77. Sickafus, K.E.; Hanrahan, R.J.; McClellan, K.J.; Mitchell, J.N.; Wetteland, C.J.; Butt, D.P.; Chodak, P.; Ramsey, K.B.; Blair, T.H.; Chidester, K.; et al. Burn and Bury Option for Plutonium. Bull. Am. Ceram. Soc. 1999, 78, 69-74.

78. Gong, W.L.; Lutze, W.; Ewing, R.C. Zirconia Ceramics for Excess Weapons Plutonium Waste. J. Nucl. Mater. 2000, 277, 239-249. [CrossRef]

79. Zacate, M.O.; Minervini, L.; Bradfield, D.J.; Grimes, R.W.; Sickafus, K.E. Defect cluster formation in $\mathrm{M}_{2} \mathrm{O}_{3}$-doped cubic $\mathrm{ZrO}_{2}$. Solid State Ion. 2000, 128, 243-254. [CrossRef]

80. Sickafus, K.E.; Minervini, L.; Grimes, R.W.; Valdez, J.A.; Ishimaru, M.; Li, F.; McClellan, K.J.; Hartmann, T. Radiation tolerance of complex oxides. Science 2000, 259, 748-751. [CrossRef]

81. Burakov, B.; Anderson, E.; Yagovkina, M.; Zamoryanskaya, M.; Nikolaeva, E. Behavior of ${ }^{238} \mathrm{Pu}$-Doped Ceramics Based on Cubic Zirconia and Pyrochlore under Radiation Damage. J. Nucl. Sci. A Technol. 2002, 3, 733-736. [CrossRef]

82. Poinssot, C.; Ferry, C.; Kelm, M.; Grambow, B.; Martinez-Esparza, A.; Johnson, L.; Andriambololona, Z.; Bruno, J.; Cachoir, C.; Cavedon, J.M.; et al. Final Report of the European Project: Spent Fuel Stability under Repository Conditions; 2005; Available online: https://inis.iaea.org/collection/NCLCollectionStore/_Public/37/ 038/37038431.pdf?r=1\&r=1 (accessed on 19 August 2019).

83. Rendtorff, N.M.; Grasso, S.; Hu, C.; Suarez, G.; Aglietti, E.F.; Sakka, Y. Zircon-zirconia $\left(\mathrm{ZrSiO}_{4}-\mathrm{ZrO}_{2}\right)$ dense ceramic composites by spark plasma sintering. J. Eur. Ceram. Soc. 2012, 32, 787-793. [CrossRef] 
84. Truphémus, T.; Belin, R.C.; Richaud, J.-C.; Reynaud, M.; Martinez, M.-A.; Félines, I.; Arredondo, A.; Miard, A.; Dubois, T.; Adenot, F.; et al. Structural studies of the phase separation in the $\mathrm{UO}_{2}-\mathrm{PuO}_{2}-\mathrm{Pu}_{2} \mathrm{O}_{3}$ ternary system. J. Nucl. Mater. Vol. 2013, 432, 378-387. [CrossRef]

85. Burakov, B.E.; Yagovkina, M.A. A study of accelerated radiation damage effects in $\mathrm{PuO}_{2}$ and gadoliniastabilized cubic zirconia, $\mathrm{Zr}_{0.79} \mathrm{Gd}_{0.14} \mathrm{Pu}_{0.07} \mathrm{O}_{1.93}$, doped with ${ }^{238} \mathrm{Pu}$. J. Nucl. Mater. 2015, 467, 534-536. [CrossRef]

86. Diaz-Guillen, J.A.; Dura, O.J.; Diaz-Guillen, M.R.; Bauer, E.; Lopez de la Torre, M.A.; Fuentes, A.F. Thermophysical properties of $\mathrm{Gd}_{2} \mathrm{Zr}_{2} \mathrm{O}_{7}$ powders prepared by mechanical milling: Effect of homovalent $\mathrm{Gd}^{3+}$ substitution. J. Alloys Compd. 2015, 649, 1145-1150. [CrossRef]

87. Orlova, A.I.; Chuvildeev, V.N. Chemistry, Crystal Chemistry and SPS technology for elaboration of perspective materials for nuclear wastes and minor actinides consolidation. J. Nucl. Energy Sci. Rower Gener. Technol. 2017, 6, 36.

88. Zhang, L.; Shelyug, A.; Navrotsky, A. Thermochemistry of $\mathrm{UO}_{2}-\mathrm{ThO}_{2}$ and $\mathrm{UO}_{2}-\mathrm{ZrO}_{2}$ Fluorite Solid Solutions. J. Chem. Thermodyn. 2017, 114, 48-54. [CrossRef]

89. Orlova, A.I.; Chuvildeev, V.N.; Nokhrin, A.V.; Boldin, M.S.; Potanina, E.A.; Mikhailov, D.A.; Golovkina, L.S.; Malanina, N.A.; Tokarev, M. Next Generation Ceramic Materials for Consolidation of radioactive alpha-wastes using the Innovative Technology Spark Plasma Sintering for their preparation. In Proceedings of the 3rd World Congress on Materials Science \& Engineering, Barcelona, Spain, 24-26 August 2017.

90. Zubekhina, B.Y.; Burakov, B.E. Plutonium leaching from polycrystalline and monocrystalline $\mathrm{PuO}_{2}$. Radiochim. Acta 2018, 106, 119-123. [CrossRef]

91. Shelyug, A.; Palomares, R.I.; Lang, M.; Navrotsky, A. Energetics of defect production in fluorite-structured $\mathrm{CeO}_{2}$ induced by highly ionizing radiation. Phys. Rev. Mater. 2018, 2, 093607. [CrossRef]

92. Zhang, L.; Dzik, E.; Sigmon, G.; Szymanowski, J.; Navrotsky, A.; Burns, P. Experimental Thermochemistry of Neptunium Oxides: $\mathrm{Np}_{2} \mathrm{O}_{5}$ and $\mathrm{NpO}_{2}$. J. Nucl. Mater. 2018, 501, 398-404. [CrossRef]

93. Yavo, N.; Sharma, G.; Kimmel, G.; Lubomirsky, I.; Navrotsky, A.; Yeheskel, O. Energetics of Bulk Lutetium Doped $\mathrm{Ce}_{1-\mathrm{x}} \mathrm{Lu}_{\mathrm{x}} \mathrm{O}_{2-\mathrm{x} / 2}$ Compounds. J. Am. Ceram. Soc. 2018, 101, 3520-3526. [CrossRef]

94. Chakoumakos, B.C. Systematics of the Pyrochlore Structure Type. Ideal $\mathrm{A}_{2} \mathrm{~B}_{2} \mathrm{X}_{6}$ Y. J. Solid State Chem. 1984, 53, 120-129. [CrossRef]

95. Chakoumakos, B.C.; Ewing, R.C. Crystal Chemical Constraints on the Formation of Actinide Pyrochlores. In Materials Research Society Symposium Proceedings. In Scientific Basis for Nuclear Waste Management; Jantzen, C.M., Stone, J.A., Ewing, R.C., Eds.; Materials Research Society: Pittsburgh, PA, USA, 1985; pp. 641-646.

96. Castro, A.; Rasines, I.; Turrillas, X.M. Synthesis, X-ray diffraction study, and ionic conductivity of new $\mathrm{AB}_{2} \mathrm{O}_{6}$ pyrochlores. J. Solid State Chem. 1989, 80, 227-234. [CrossRef]

97. Sobolev, I.A.; Stefanovsky, S.V.; Omelianenko, B.I.; Ioudintsev, S.V.; Vance, E.R.; Jostsons, A. Comparative Study of Synroc-C Ceramics Produced by Hotpressing and Inductive Melting. Mater. Res. Soc. Symp. Proc. 1997, 465, 371-378. [CrossRef]

98. Yudintsev, S.V.; Yudintseva, T.S. Nonstoichiometry of pyrochlore $\mathrm{Ca}(\mathrm{U}, \mathrm{Pu}) \mathrm{Ti}_{2} \mathrm{O}_{7}$ and problem of brannerite $(\mathrm{U}, \mathrm{Pu}) \mathrm{Ti}_{2} \mathrm{O}_{6}$ in ceramic for actinide immobilization. In Proceedings of the 8 th International Conference on Radioactive Waste Management and Environmental Remediation, Bruges, Belgium, 30 September-4 October 2001; ASME: New York, NY, USA, 2011; Volume 2, pp. 547-552.

99. Kar, T.; Choudhary, R.N.P. Structural, dielectric and electrical conducting properties of $\mathrm{CsB}^{\prime} \mathrm{B}^{\prime \prime} \mathrm{O}_{6}\left(\mathrm{~B}^{\prime}=\mathrm{Nb}\right.$, Ta; B" = W, Mo) ceramics. Mater. Sci. Eng. 2002, B90, 224-233. [CrossRef]

100. Ewing, R.C.; Weber, W.J.; Lian, J. Pyrochlore $\left(\mathrm{A}_{2} \mathrm{~B}_{2} \mathrm{O}_{7}\right)$ : A Nuclear Waste Form for the Immobilization of Plutonium and "Minor" Actinides, (Focus Review). J. Appl. Phys. 2004, 95, 5949-5971. [CrossRef]

101. Whittle, K.R.; Lumpkin, G.R.; Ashbrook, S.E. Neutron diffraction and MAS NMR of Cesium Tungstate defect pyrochlores. J. Solid State Chem. 2006, 179, 512-521. [CrossRef]

102. Thorogood, G.J.; Saines, P.J.; Kennedy, B.J.; Withers, R.L.; Elcombe, M.M. Diffuse scattering in the cesium pyrochlore $\mathrm{CsTi}_{0.5} \mathrm{~W}_{1.5} \mathrm{O}_{6}$. Mater. Res. Bull. 2008, 43, 787-795. [CrossRef]

103. Fukuda, K.; Akatsuka, K.; Ebina, Y.; Ma, R.; Takada, K.; Nakai, I.; Sasaki, T. Exfoliated Nanosheet Crystallite of Cesium Tungstate with 2D Pyrochlore. Structure: Synthesis, Characterization, and Photochromic Properties. ACS Nano 2008, 2, 1689-1695. [CrossRef] 
104. Lukinykh, A.N.; Tomilin, S.V.; Lizin, A.A.; Yudintsev, S.V. Radiation and Chemical durability of Actinide Crystalline Matrices, In Book of Abstracts. In Proceedings of the III International Pyroprocessing Research Conference, Dimitrovgrad, Russia, 29 November-3 December 2010; Volume 42.

105. Laverov, N.P.; Yudintsev, S.V.; Livshits, T.S.; Stefanovsky, S.V.; Lukinykh, A.N.; Ewing, R.C. Synthetic Minerals with the Pyrochlore and Garnet Structures for Immobilization of Actinide-Containing Wastes. Geochem. Int. 2010, 48, 1-14. [CrossRef]

106. Laverov, N.P.; Urusov, V.S.; Krivovichev, S.V.; Pakhomova, A.S.; Stefanovsky, S.V.; Yudintsev, S.V. Modular Nature of the Polysomatic Pyrochlore-Murataite Series. Geol. Ore Depos. 2011, 53, 273-294. [CrossRef]

107. Hartmann, T.; Alaniz, A.; Poineau, F.; Weck, P.F.; Valdes, J.A.; Tang, M.; Jarvinen, G.D.; Czerwinski, K.R.; Sickafus, K.E. Structure studies on lanthanide technetium pyrochlores as prospective host phases to immobilize 99 technetium and fission lanthanides from effuents of reprocessed used nuclear fuels. J. Nucl. Mater. 2011, 411, 60-71. [CrossRef]

108. Krivovichev, S.V.; Urusov, V.S.; Yudintsev, S.V.; Stefanovsky, S.V.; Karimova, O.V.; Organova, N.N. Crystal Structure of Murataite Mu-5, a Member of the Murataite-Pyrochlore Polysomatic Series. In Minerals as Advanced Materials II; Springer: Berlin/Heidelberg, Germany, 2012; pp. 293-304.

109. Gregg, D.J.; Zhang, Y.; Middleburgh, S.C.; Conradson, S.D.; Lumpkin, G.R.; Triani, G.; Vance, E.R. The incorporation of plutonium in lanthanum zirconate pyrochlores. J. Nucl. Mater. 2013, 443, 444-451. [CrossRef]

110. Nash, K.L.; Lumetta, G.J.; Vienna, J.D. Irradiated nuclear Fuel management: resource versus waste. In Radioactive Waste Management and Contaminated Siite Clean-up. Processes, Technologies and International Experience; Lee, W.E., Ojovan, M.I., Jansen, M.C., Eds.; Woodhead Publishing Limited: Oxford, UK; Cambridge, UK; Philadelphia, PA, USA; New Delhi, India, 2013; Chapter 5; pp. 145-170.

111. Yudintsev, S.V.; Stefanovsky, S.V.; Nikonov, B.S. A Pyrochlore based matrix for isolation of the REE-actinide fraction of wastes from spent nuclear fuel reprocessing. Dokl. Earth Sci. 2014, 454, 54-58. [CrossRef]

112. Jafar, M.; Sengupta, P.; Achary, S.N.; Tuagi, A.K. Phase evolution and microstructural studies in $\mathrm{CaZrTi}_{2} \mathrm{O}_{7}$ (zirconolite)- $\mathrm{Sm}_{2} \mathrm{Ti}_{2} \mathrm{O}_{7}$ (pyroclore) system. J. Eur. Ceram. Soc. 2014, 34, 4373-4381. [CrossRef]

113. Jafar, M.; Sengupta, P.; Achary, S.N.; Tuagi, A.K. Phase Evolution and Microstructural Studies in $\mathrm{CaZrTi}_{2} \mathrm{O}_{7}$ $-\mathrm{Nd}_{2} \mathrm{Ti}_{2} \mathrm{O}_{7}$ System. J. Am. Ceram. Soc. 2014, 97, 609-616. [CrossRef]

114. Hollmann, D.; Merka, O.; Schwertmann, L.; Marschall, R.; Wark, M.; Brückner, A. Active Sites for Light Driven Proton Reduction in $\mathrm{Y}_{2} \mathrm{Ti}_{2} \mathrm{O}_{7}$ and $\mathrm{CsTaWO}_{6}$ Pyrochlore Catalysts Detected by In Situ EPR. Top. Catal. 2015, 58, 769-775. [CrossRef]

115. Kim, J.; Shih, P.-C.; Tsao, K.-C.; Pan, Y.-T.; Yin, X.; Sun, C.-J.; Yang, H. High-Performance Pyrochlore-Type Yttrium Ruthenate. Electrocatalyst for Oxygen Evolution Reaction in Acidic Media. J. Am. Chem. Soc. 2017, 139, 12076-12083. [CrossRef]

116. McMaster, S.A.; Ram, R.; Faris, N.; Pownceby, M.I. Radionuclide disposal using the pyrochlore supergroup of minerals as a host matrix-A review. J Hazard Mater. 2018, 360, 257-269. [CrossRef]

117. Kim, J.; Shih, P.-C.; Qin, Y.; Al-Bardan, Z.; Sun, C.-J.; Yang, H. A Porous Pyrochlore $\mathrm{Y}_{2}\left[\mathrm{Ru}_{1.6} \mathrm{Y}_{0.4}\right] \mathrm{O}_{7^{-}}$ $\delta$ Electrocatalyst for Enhanced Performance towards the Oxygen Evolution Reaction in Acidic Media. Angew. Chem. Int. Ed. 2018, 57, 13877-13881. [CrossRef]

118. Morgan, P.E.D.; Ryerson, F.J. A new “Cubic" Crystal Compound. J. Mater. Sci. Lett. 1982, 1, $351-352$. [CrossRef]

119. Sobolev, I.A.; Stefanovsky, S.V.; Ioudintsev, S.V.; Nikonov, B.S.; Omelianenko, B.I.; Mokhov, A.V. Study of Melted Synroc Doped with Simulated High-level Waste. Mater. Res. Soc. Symp. Proc. 1997, 465, 363-370. [CrossRef]

120. Stefanovsky, S.V.; Yudintsev, S.V.; Nikonov, B.S.; Mokhov, A.V.; Perevalov, S.A.; Stefanovsky, O.I.; Ptashkin, A.G. Phase Compositions and Leach Resistance of Actinide-Bearing Murataite Ceramics. Mater. Res. Soc. Symp. Proc. 2006, 893, 0893-JJ05-23. [CrossRef]

121. Lian, I.; Yudintsev, S.V.; Stefanovsky, S.V.; Kirjanova, O.I.; Ewing, R.C. Ion Induced Amorphization of Murataite. Mater. Res. Soc. Symp. Proc. 2002, 713, 455-460. [CrossRef]

122. Urusov, V.S.; Organova, N.I.; Karimova, O.V.; Yudintsev, S.V.; Stefanovsky, S.V. Synthetic "Murataits" as Modular Members of Pyrochlore-Murataite Polysomatic Series. Dokl. Earth Sci. 2005, 401, 319-325.

123. Stefanovsky, S.V.; Yudintsev, S.V.; Nikonov, B.S.; Stefanovsky, O.I. Rare Earth-Bearing Murataite Ceramics. Mater. Res. Soc. Symp. Proc. 2007, 985, 175-180. [CrossRef] 
124. Stefanovsky, S.V.; Ptashkin, A.G.; Knyazev, O.A.; Dimitriev, S.A.; Yudintsev, S.V.; Nikonov, B.S. Inductive Cold Crucible Melting of Actinide-bearning Murataite-based Ceramics. J. Alloys Compd. 2007, 444, 438-442. [CrossRef]

125. Stefanovsky, S.V.; Yudintsev, S.V.; Perevalov, S.A.; Startseva, I.V.; Varlakova, G.A. Leach Resistance of Murataite-based Ceramics Containing Actinides. J. Alloys Compd. 2007, 444, 618-620. [CrossRef]

126. Stefanovsky, S.V.; Ptashkin, A.G.; Knyazev, O.A.; Zen'kovskaja, M.S.; Stefanovsky, O.I.; Yudintsev, S.V.; Nikonov, B.S.; Lapina, M.I. Melted Murataite Ceramics Containing Simulated Actinide/Rere Earth Fraction of High Level Waste. In Proceedings of the WM2008 Conference, Phoenix, AZ, USA, 24-28 February 2008.

127. Krivovichev, S.V.; Yudintsev, S.V.; Stefanovsky, S.V.; Organova, N.I.; Karimova, O.V.; Urusov, V.S. Murataite-Pyrochlore Series: A Family of Complex Oxides with Nanoscale Pyrochlore Clusters. Angew. Chem. Int. Ed. 2010, 49, 9982-9984. [CrossRef]

128. Laverov, N.P.; Yudintsev, S.V.; Stefanovskii, S.V.; Omel'yanenko, B.I.; Nikonov, B.S. Murataite Matrices for Actinide Wastes. Radiochemistry 2011, 53, 229-243. [CrossRef]

129. Pakhomova, A.S.; Krivovichev, S.V.; Yudintsev, S.V.; Stefanovsky, S.V. Synthetic Murataite-3c, a complex form for long-term immobilization of nuclear waste: crystal structure and its comparison with natural analogue. Z. Kristallogr 2013, 228, 151-156. [CrossRef]

130. Poglyad, S.S.; Pryzhevskaya, E.A.; Lizin, A.A.; Tomilin, S.V.; Murasova, O.V. On possibility of the murataite fusion temperature lowering for radioactive waste immobilization. J. Phys. Conf. Ser. 2018, 1133, 012019. [CrossRef]

131. Lizin, A.A.; Tomilin, S.V.; Poglyad, S.S.; Pryzhevskaya, E.A.; Yudintsev, S.V.; Stefanovsky, S.V. Murataite: a matrix for immobilizing waste generated in radiochemical reprocessing of spent nuclear fuel. J. Radioanal. Nucl. Chem. 2018, 318, 2363-2372. [CrossRef]

132. Clinard, F., Jr.; Hobbs, L.W.; Land, C.C.; Peterson, D.E.; Rohr, D.L.; Roof, R.B. Alpha Decay Self-irradiation Damage in 238Pu-substituted Zirconolite. J. Nucl. Mater. 1982, 105, 248-256.

133. Clinard, F., Jr.; Peterson, D.E.; Rohr, D.L.; Hobbs, L.W. Self-irradiation Effects in 238Pu-substituted Zirconolite: I. Temperature Dependence of Damage. J. Nucl. Mater. 1984, 126, 245-254.

134. Boult, K.A.; Dalton, J.T.; Evans, J.P.; Hall, A.R.; Inns, A.J.; Marples, J.A.C.; Paige, E.L. The Preparation of fully-active Synroc and its radiation stability-Final Report October 1988; UKAEA: Harwell, UK, 1988.

135. Vance, E.R.; Ball, C.J.; Day, R.A.; Smith, K.L.; Blackford, M.G.; Begg, B.D.; Angel, P.J. Actinide and Rare Earth Incorporation in Zirconolite. J. Alloys Compd. 1994, 213-214, 406-409. [CrossRef]

136. Vance, E.R.; Angel, P.J.; Begg, B.D.; Day, R.A. Zirconolite-Rich Titanate Ceramics for High-Level Actinide Wastes. In Scientific Basis for Nuclear Waste Management XVII; van Konynenburg, R., Barkatt, A.A., Eds.; Materials Research Society: Pittsburgh, PA, USA, 1994; pp. 293-298.

137. Zhang, Y.; Stewart, M.W.A.; Li, H.; Carter, M.L.; Vance, E.R.; Moricca, S. Zirconolite-rich Titanate Ceramics for Immobilization of Actinides-Waste form/HIP Can Interactions and Chemical Durability. J. Nucl. Mater. 2009, 395, 69-74. [CrossRef]

138. Whittle, K.R.; Hyatt, N.C.; Smith, K.L.; Margiolaki, I.; Berry, F.J.; Knight, K.E.; Lumpkin, G.R. Combined neutron and X-ray diffraction determination of disorder in doped zirconolite-2M. Am. Mineral. 2012, 97, 291-298. [CrossRef]

139. Bohre, A.; Avasthi, K.; Shrivastava, O.P. Synthesis, Characterization, and Crystal Structure Refinement of Lanthanum and Yttrium Substituted Polycrystalline 2M Type Zirconolite Phases: $\mathrm{Ca}_{1-\mathrm{x}} \mathrm{Me}_{\mathrm{x}} \mathrm{ZrTi}_{2} \mathrm{O}_{7}(\mathrm{Me}=\mathrm{Y}$, La and $\mathrm{x}=0.2)$. J. Powder Technol. 2014, 2014, 1-10. [CrossRef]

140. Lumpkin, G.R.; Gao, Y.; Giere, R.; Williams, C.T.; Mariano, A.N.; Geisler, T. The role of Th-U minerals in assessing the performance of nuclear waste forms. Mineral. Mag. 2014, 78, 1071-1095. [CrossRef]

141. Deschanels, K.; Seydonx-Guillaume, A.M.; Morgin, V.; Mesbah, A.; Tribet, M.; Moloney, M.P.; Serruys, Y.; Peuget, S. Swelling induced by alpha decay in monazite and zirconolite ceramics: A XRD and TEM comparative study. J. Nucl. Mater. 2014, 448, 184-194. [CrossRef]

142. Zhang, K.; Wen, G.; Zhang, H.; Teng, Y. Self-propagating high-temperature synthesis of $\mathrm{CeO}_{2}$ incorporated zirconolite-rich waste forms and the aqueous durability. J. Eur. Cream. Soc. 2015, 35, 3085-3093. [CrossRef]

143. Zhang, K.; Wen, G.; Jia, Z.; Teng, Y.; Zhang, H. Self-Propagating High-Temperature Synthesis of Zirconolite Using $\mathrm{CuO}$ and $\mathrm{MoO}_{3}$ as the Oxidants. Int. J. Appl. Ceram. Technol. 2015, 12, E111-E120. [CrossRef]

144. Wen, G.; Zhang, K.; Yin, D.; Zhang, H. Solid-state reaction synthesis and aqueous durability of Ce-doped zirconolite-rich ceramics. J. Nucl. Mater. 2015, 466, 113-119. [CrossRef] 
145. Popa, K.; Cologna, M.; Martel, L.; Staicu, D.; Cambriani, A.; Ernstberger, M.; Raison, P.E.; Somers, J. $\mathrm{CaTh}\left(\mathrm{PO}_{4}\right)_{2}$ cheralite as a candidate ceramic nuclear waste form: Spark plasma sintering and physicochemical characterization. J. Eur. Ceram. 2016, 36, 4115-4121. [CrossRef]

146. Wen, J.; Sun, C.; Dholabhai, P.P.; Xia, Y.; Tang, M.; Chen, D.; Yang, D.Y.; Li, Y.H.; Uberuaga, B.P.; Wang, Y.Q. Temperature dependence of the radiation tolerance of nanocrystalline pyrochlores $\mathrm{A}_{2} \mathrm{Ti}_{2} \mathrm{O}_{7}(\mathrm{~A}=\mathrm{Gd}, \mathrm{Ho}$ and Lu). Acta Mater. 2016, 110, 175-184. [CrossRef]

147. Clark, B.M.; Sundaram, S.K.; Misture, S.T. Polymorphic Transitions in Cerium-Substituted Zirconolite $\left(\mathrm{CaZrTi}_{2} \mathrm{O}_{7}\right)$. Sci. Rep. 2017, 7, 5920. [CrossRef]

148. Sun, S.K.; Stennett, M.C.; Corkhill, C.L. Reactive spark plasma synthesis of $\mathrm{CaZrTi}_{2} \mathrm{O}_{7}$ zirconolite ceramics for plutonium disposition. J. Nucl. Mater. 2018, 500, 11-14. [CrossRef]

149. McCaughherty, S.; Crosvenor, A.P. Low-temperature synthesis of $\mathrm{CaZrTi}_{2} \mathrm{O}_{7}$ zirconolite-type materialss using ceramic, coprecipitation, and soil-gel methods. J. Mater. Chem. C 2019, 7, 177-187. [CrossRef]

150. Zhang, K.; Yin, D.; Xu, K.; Zhang, H. Self-Propagating Synthesis and Characterization Studies of Gd-Bearing Hf-Zirconolite Ceramic Waste Forms. Materials 2019, 12, 178. [CrossRef]

151. Boult, A.; Dalton, J.T.; Evans, J.P.; Hall, A.R.; Inn, A.J.; Marples, J.A.C.; Paige, E.L. The Preparation of Fully-active Synroc and its Radiation Stability. Rep. Aere-R. 1987, 13, 318.

152. Vance, E.R.; Carter, M.L.; Zhang, Z.; Finnie, K.S.; Thomson, S.J.; Begg, B.D. Uranium valences in perovskite, $\mathrm{CaTiO}_{3}$. In Environmental Issues and Waste Management Technologies in the Ceramic $\mathcal{E}$ Nuclear Industries IX; The American Ceramic Society: Westeville, OH, USA, 2004; Volume 155, pp. 3-10.

153. Bozadjiev, L.; Georgiev, G.; Parashkevov, D. Synthesis of perovskites and perovskite based technical stones. In National Conference “GEOSCIENSES 2006"; Bulgarian Geophysical Society: Sofia, Bulgaria, 2006; pp. 127-129.

154. Bowles, J.F.W.; Howie, R.A.; Vaughan, D.J.; Zussman, J. Rock-Forming Minerals, V5A: Non-Silicates: Oxides, Hydroxides and Sulphides; The Geological Society: London, UK, 2011; p. 920.

155. Stewart, M.W.A.; Vance, E.R.; Moricca, S.A.; Brew, D.R.; Cheung, C.; Eddowes, T.; Bermudez, W. Immobilisation of Higher Activity Wastes from Nuclear Reactor Production of ${ }^{99}$ Mo. Sci. Technol. Nucl. Install. 2013, 2013, 1-16. [CrossRef]

156. Ghosh, B.; Dutta, A.; Shannigrahi, S.; Sinha, T.P. Combined XPS and first principles study of double-perovskite $\mathrm{Ca}_{2} \mathrm{GdTaO}_{6}$. J. Mater. Sci. 2014, 49, 819-826. [CrossRef]

157. Bohre, A.; Avasthi, K.; Shrivastava, O.P. Structure Refinement of Polycrystalline Orthorombic Calcium Titanate Substituted by Lanthanum: $\mathrm{Ca}_{1-\mathrm{x}} \mathrm{Ln}_{\mathrm{x}} \mathrm{TiO}_{3}(\mathrm{x}=0.1-0.4)$. Crystallogr. Rep. 2014, 59, 944-948. [CrossRef]

158. Livshits, T.S.; Zhang, J.; Yudintsev, S.V.; Stefanovsky, S.V. New titanate matrices for immobilization of REE-actinide high level waste. J. Radioanal. Nucl. Chem. 2014, 304, 47-52. [CrossRef]

159. Mahadik, P.S.; Sengupta, P.; Halder, R.; Abraham, G.; Dey, G.K. Perovskite-Ni composite: A potential route for management of radioactive metallic waste. J. Hazard. Mater. 2015, 287, 207-216. [CrossRef]

160. Carter, M.L.; Vance, E.R.; Mitchell, D.R.G.; Hanna, J.V.; Zhang, Z.; Loi, E. Fabrication, Characterization, and Leach Testing of Hollandite, $(\mathrm{Ba}, \mathrm{Cs})(\mathrm{Al}, \mathrm{Ti})_{2} \mathrm{Ti}_{6} \mathrm{O}_{16}$. J. Mater. Res. 2002, 17, 2578-2589. [CrossRef]

161. Carter, M.L.; Vance, E.R.; Li, H. Hollandite-rich Ceramic Melts for the Immobilization of Cs. Mater. Res. Soc. Proc. 2004, 807, 249-254. [CrossRef]

162. Whittle, K.R.; Ashbrook, S.; Redfem, S.; Lumpkin, G.R. Structural Studies of Hollandite-Based Radioactive Waste Forms Structural Studies of Hollandite-Based Radioactive Waste Forms. Mater. Res. Soc. Symp. Proc. 2004, 87, 1-7.

163. Nishiyama, N.; Rapp, R.P.; Irifune, T.; Sanehira, T.; Yamazaki, D.; Funakoshi, K. Stability and P-V-T equation of state $\mathrm{KAlSi}_{3} \mathrm{O}_{8}$-hollandite determined by in situ X-Ray observations and implications for dynamics of subducted continental crust material. Phys. Chem. Miner. 2005, 32, 627-637. [CrossRef]

164. Addelouas, A.; Utsunomiya, S.; Suzuki, T.; Grambow, B.; Advocat, T.; Bart, F.; Ewing, R.C. Effect of ionizing radiation on the hollandite structure-type: $\mathrm{Ba}_{0.85} \mathrm{Cs}_{0.26} \mathrm{Al}_{1.35} \mathrm{Fe}_{0.77} \mathrm{Ti}_{5.90} \mathrm{O}_{16}$. Am. Mineral. 2008, 93, $241-247$. [CrossRef]

165. Shluk, L.; Niewa, R. Crystal Structure and Magnetic Properties of the Novel Hollandite $\mathrm{Ba}_{1.3} \mathrm{Co}_{1.3} \mathrm{Ti}_{6.7} \mathrm{O}_{16}$. Z. Naturforsch. 2011, 66b, 1097-1100. [CrossRef]

166. Shabalin, B.; Titov, Y.; Zlobenko, B.; Bugera, S. Ferric Titanous Hollandite Analogues-Matrices for Immobilization of Cs-Containing Radioactive Waste: Synthesis. Mineral. J. 2013, 35, 12-18. 
167. Chen, T.-Y.; Maddrell, E.R.; Hyatt, N.C.; Hriljac, J.A. A potential wasteform for Cs immobilization: synthesis, structure determination, and aqueous durability of $\mathrm{Cs}_{2} \mathrm{TiNb}_{6} \mathrm{O}_{18}$. Inorg. Chem. 2016, 55, 12686-12695. [CrossRef] [PubMed]

168. Zhao, M.; Xu, Y.; Shuller-Nickles, L.; Amoroso, J.; Frenkel, A.I.; Li, Y.; Gong, W.; Lilova, K.; Navrotsky, A.; Brinkman, K.S. Compositional control of radionuclide retention in hollandite-based ceramic waste forms for Cs immobilization. J. Am. Ceram. Soc. 2018, 102, 4314-4324. [CrossRef]

169. Grote, R.; Zhao, M.; Shuller-Nickles, L.; Amoroso, J.; Gong, W.; Lilova, K.; Navrotsky, A.; Tang, M.; Brinkman, K.S. Compositional control of tunnel features in hollandite-based ceramics: Structure and stability of $(\mathrm{Ba}, \mathrm{Cs})_{1.33}(\mathrm{Zn}, \mathrm{Ti})_{8} \mathrm{O}_{16}$. J. Mater. Sci. 2018, 54, 1112-1125. [CrossRef]

170. Geller, S.; Miller, C.E. Silicate garnet yttrium-iron garnet solid solution. Am. Mineral. 1959, 44, 1115-1120.

171. Ito, J.; Frondel, C. Synthesis zirconium and titanium garnets. Am. Mineral. 1967, 52, 773-781.

172. Rickwood, P.C. On recasting analyses of garnet into end-member molecules. Contrib. Mineral. Petrol. 1968, 18, 175-198. [CrossRef]

173. Novak, G.A.; Gibbs, G.V. The crystal chemistry of the silicate garnets. Am. Mineral. 1971, 56, 791-825.

174. Dowty, E. Crystal chemistry of titanian and zirconian garnet: I. Review and spectral studies. Am. Mineral. 1971, 56, 1983-2009.

175. Kanke, Y.; Navrotsky, A. A calorimetric study of the lanthanide aluminum oxides and the lantha-nide gallium oxides: Stability of the perovskites and the garnets. J. Solid State Chem. 1998, 141, 424-436. [CrossRef]

176. Burakov, B.E.; Anderson, E.B.; Zamoryanskaya, M.V.; Petrova, M.A. Synthesis and Study of ${ }^{239}$ Pu-Doped Gadolinium-Aluminum Garnet. In Material Research Society Symposium Proceedings Scientific Basis for Nuclear Waste Management XXIII; Materials Research Society: Warendalle, PA, USA, 2000; Volume 608, pp. 419-422.

177. Yudintsev, S.V. Incorporation of $U, T h, Z r$, and Gd into the Garnet-structured Host. In Proceedings of the 8th International Conference on Radioactive Waste Management and Environmental Remediation, The American Society of Mechanical Engineers, Bruges, Belgium, 30 September-4 October 2001.

178. Yudintsev, S.V.; Lapina, M.I.; Ptashkin, A.G. Accommodation of uranium into the garnet structure. MRS Symp. Proc. 2002, 713, 477-480. [CrossRef]

179. Utsunomiya, S.; Wang, L.M.; Yudintsev, S.; Ewing, R.C. Ion irradiation-induced amorphization and nano-crystal formation in garnets. J. Nucl. Mater. 2002, 303, 177-187. [CrossRef]

180. Yudintsev, S.V. A Structural-chemical Approach to Selecting Crystalline Matrices for Actinide Immobilization. Geol. Ore Depos. 2003, 45, 151-165.

181. Utsunomiya, S.; Yudintsev, S.V.; Ewing, R.C. Radiation effects in ferrate garnet. J. Nucl. Mater. 2005, 336, 251-260. [CrossRef]

182. Maslakov, K.I.; Teterin, U.A.; Vukchevich, L.; Udintseva, T.C.; Udintsev, S.V.; Ivanov, K.E.; Lapina, M.I. Issledovanie obraztsov keramiki $\left(\mathrm{Ca}_{2.5} \mathrm{Th}_{0.5}\right) \mathrm{Zr}_{2} \mathrm{Fe}_{3} \mathrm{O}_{12},\left(\mathrm{Ca}_{1.5} \mathrm{GdTh}_{0.5}\right)(\mathrm{ZrFe}) \mathrm{Fe}_{3} \mathrm{O}_{12} \mathrm{i}\left(\mathrm{Ca}_{2.5} \mathrm{Ce}_{0.5}\right) \mathrm{Zr}_{2} \mathrm{Fe}_{3} \mathrm{O}_{12}$ so strukturoi granata. Radiohimiya 2007, 49, 31-37.

183. Suarez, M.; Fernandez, A.; Menendez, J.L.; Torrecillas, R. Transparent Yttrium Aluminium Garnet Obtained by Spark Plasma Sintering of Lyophilized Gels. J. Nanomater. 2009, 2009, 1-5. [CrossRef]

184. Tomilin, S.V.; Lizin, A.A.; Lukinykh, A.N.; Livshits, T.S. Radiation Resistance and Chemical of Yttrium Aluminium Garnet. Radiochemistry 2011, 53, 186-190. [CrossRef]

185. Golovkina, L.S.; Orlova, A.I.; Nokhrin, A.V.; Boldin, M.S.; Sakharov, N.V. Ceramics based on Yttrium Aluminium Garnet Containing Nd and Sm obtained by Spark Plasma Sintering. Adv. Ceram. Sci. Eng. 2013, 2, 261-265.

186. Hanc, E.; Zając, W.; Lu, L. On fabrication procedures of Li-ion conducting garnets. J. Solid State Chem. 2017, 248, 51-60. [CrossRef]

187. Yamada, H.; Ito, T.; Basappa, R.H.; Bekarevich, R.; Mitsuishi, K. Influence of strain on local structure and lithium ionic conduction in garnet-type solid electrolyte. J. Power Sources 2017, 368, 97-106. [CrossRef]

188. Selvi, M.M.; Chakraborty, D.; Venkateswaran, C. Magnetodielectric coupling in multiferroic holmium iron garnets. J. Magn. Magn. Mater. 2017, 423, 39-45. [CrossRef]

189. Golovkina, L.; Orlova, A.; Boldin, M.; Sakharov, N.; Chuvil'deev, V.; Nokhrin, A.; Konings, R.; Staicu, D. Development of composite ceramic materials with improved thermal conductivity and plasticity based on garnet-type oxides. J. Nucl. Mater. 2017, 489, 158-163. [CrossRef] 
190. Golovkina, L.S.; Nokhrin, A.V.; Boldin, M.S.; Lantsev, E.A.; Orlova, A.I.; Chuvil'deev, V.N.; Murashov, A.A.; Sakharov, N.V. Preparation of Fine-Grained $\mathrm{Y}_{2.5} \mathrm{Nd}_{0.5} \mathrm{Al}_{5} \mathrm{O}_{12}+\mathrm{MgO}$ composite ceramics for Inert Matrix Fuels by Spark Plasma Sintering. Inorg. Mater. 2018, 54, 1291-1298. [CrossRef]

191. Golovkina, L.S.; Orlova, A.I.; Nokhrin, A.V.; Boldin, M.S.; Lantsev, E.A.; Chuvil'deev, V.N.; Sakharov, N.V.; Shotin, S.V.; Zelenov, A.Y. Spark Plasma Sintering of fine-grained ceramic-metal composites YAG: Nd-(W,Mo) based on garnet-type oxide $\mathrm{Y}_{2.5} \mathrm{Nd}_{0.5} \mathrm{Al}_{5} \mathrm{O}_{12}$ for inert matrix fuel. J. Nucl. Mater. 2018, 511, 109-121. [CrossRef]

192. Golovkina, L.S.; Orlova, A.I.; Nokhrin, A.V.; Boldin, M.S.; Chuvil'deev, V.N.; Sakharov, N.V.; Belkin, O.A.; Shotin, S.V.; Zelenov, A.Y. Spark Plasma Sintering of fine-grain ceramic-metal composites based on garnet-structure oxide $\mathrm{Y}_{2.5} \mathrm{Nd}_{0.5} \mathrm{Al}_{5} \mathrm{O}_{12}$ for inert matrix fuel. Mater. Chem. Phys. 2018, 214, 516-526. [CrossRef]

193. Golovkina, L.S.; Orlova, A.I.; Chuvil'deev, V.N.; Boldin, M.S.; Lantcev, E.A.; Nokhrin, A.V.; Sakharov, N.V.; Zelenov, A.Y. Spark Plasma Sintering of high-density fine-grained $\mathrm{Y}_{2.5} \mathrm{Nd}_{0.5} \mathrm{Al}_{5} \mathrm{O}_{12}+\mathrm{SiC}$ composite ceramics. Mater. Res. Bull. 2018, 103, 211-215. [CrossRef]

194. Golovkina, L.; Orlova, A.; Boldin, M.; Lantsev, E.; Sakharov, N.; Zelenov, A.; Chuvil'deev, V. Composite Ceramics Based on Garnet-type Oxide $\mathrm{Y}_{2.5} \mathrm{Nd}_{0.5} \mathrm{Al}_{5} \mathrm{O}_{12}$ and Silicon Carbide. Mater. Res. Bull. 2018, 4, $518-524$.

195. Gong, W.L.; Ewing, R.C.; Wang, L.M.; Xie, H.S. Crichtonite Structure Type $\left(\mathrm{AM}_{21} \mathrm{O}_{38}\right.$ and $\left.\mathrm{A}_{2} \mathrm{M}_{19} \mathrm{O}_{36}\right)$ as a Host Phase in Crystalline Waste Form Ceramics. Scientific Basis for Nuclear Waste Management XVIII. T. Murakami and R.C. Ewing, Eds. Proc. Mater. Res. Soc. 1995, 353, 807-815. [CrossRef]

196. Grey, I.E.; Lloyd, D.J.; White, J.S., Jr. The Structure of Crichtonite and its Relationship to Senaite. Am. Mineral. 1976, 61, 1203-1212.

197. Wulser, P.-A.; Meisser, N.; Brugger, J.; Schenk, K.; Ansermet, S.; Bonin, M.; Bussy, F. Cleusonite, $(\mathrm{Pb}, \mathrm{Sr})\left(\mathrm{U}^{4+}, \mathrm{U}^{6+}\right)\left(\mathrm{Fe}^{2+}, \mathrm{Zn}\right)_{2}\left(\mathrm{Ti}, \mathrm{Fe}^{2+}, \mathrm{Fe}^{3+}\right)_{18}(\mathrm{O}, \mathrm{OH})_{38}$, a new mineral species of the crichtonite group from the western Swiss Alps. Eur. J. Mineral. 2005, 17, 933-942. [CrossRef]

198. Mills, S.J.; Bindi, L.; Cadoni, M.; Kampf, A.R.; Ciriotti, M.E.; Ferraris, G. Paseroite, $\mathrm{PbMn}^{2+}\left(\mathrm{Mn}^{2+}{ }_{,} \mathrm{Fe}^{2+}\right)_{2}\left(\mathrm{~V}^{5+}, \mathrm{Ti}, \mathrm{Fe}^{3+}, \square\right){ }_{18} \mathrm{O}_{38}$, a new member of the crichtonite group. Eur. J. Mineral. 2012, 24, 1061-1067. [CrossRef]

199. Rastsvetaeva, R.K.; Aksenov, S.M.; Chukanov, N.V.; Menezes, L.A.D. Crystal Structure of Almeidaite, a New Mineral of the Crichtonite Group. Dokl. Chem. 2014, 455, 53-57. [CrossRef]

200. Biagioni, C.; Orlandi, P.; Pasero, M.; Nestola, F.; Bindi, L. Mapiquiroite, $(\mathrm{Sr}, \mathrm{Pb})(\mathrm{U}, \mathrm{Y}) \mathrm{Fe}_{2}\left(\mathrm{Ti}_{1} \mathrm{Fe}^{3+}\right)_{18} \mathrm{O}_{38}$, a new member of the crichtonite group from the Apuan Alps, Tuscany, Italy. Eur. J. Mineral. 2014, 26, 427-437. [CrossRef]

201. Menezes Filho, L.A.D.; Chukanov, N.V.; Rastsvetaeva, R.K.; Aksenov, S.M.; Pekov, I.V.; Chaves, M.L.S.C.; Richards, R.P.; Atencio, D.; Brandao, P.R.G.; Scholz, R.; et al. Almeidaite, $\mathrm{Pb}(\mathrm{Mn}, \mathrm{Y}) \mathrm{Zn}_{2}\left(\mathrm{Ti}_{1} \mathrm{Fe}^{3+}\right)_{18} \mathrm{O}_{36}(\mathrm{O}, \mathrm{OH})_{2}$, a new crichtonite-group mineral, from Novo Horizonte, Bahia. Braz. Mineral. Mag. 2015, 79, $269-283$. [CrossRef]

202. Rezvukhin, D.I.; Malkovets, V.G.; Sharygin, I.S.; Kuzmin, D.V.; Gibsher, A.A.; Litasov, K.D.; Pokhilenko, A.P.; Sobolev, N.V. Inclusions of Crichtonite Group Minerals in Pyropes from the Internatsionalnaya Kimberlite Pipe. Dokl. Akad. Nauk. 2016, 466, 714-717. [CrossRef]

203. Ishiguro, T.; Tanaka, K.; Marumo, F.; Ismail, M.G.M.U.; Hirano, S. Somiya, Freudenbergite. Acta Cryst. 1978, B34, 255-256. [CrossRef]

204. Vance, E.R.; Angel, P.J.; Cassidy, D.J.; Stewart, M.W.A.; Blackford, M.G.; McGlinn, P.A. Freudenbergite: A Possible Synroc Phase for Sodium-Bearing High-Level Waste. J. Am. Ceram. Soc. 1994, 77, 1576-1580. [CrossRef]

205. Ren, X.; Komarneni, S.; Roy, D.M. Novel $\mathrm{CsAl}_{2} \mathrm{PO}_{6}$ of pollucite structure: synthesis and characterization. Mater. Res. Bull. 1990, 25, 665-670. [CrossRef]

206. Komarneni, S.; Menon, V.C.; Li, Q.H.; Roy, R.; Ainger, F. Microwave-hydrothermal processing of $\mathrm{BiFeO}_{3}$ and $\mathrm{CsAl}_{2} \mathrm{PO}_{6}$. J. Am. Ceram. Soc. 1996, 75, 1409-1412. [CrossRef]

207. Aloy, A.S.; Kol'tsova, T.I.; Trofimenko, A.V.; Tutov, A.G. New compound with pollucite structure forming in process of synthesis and crystallization of cesium-alumphosphate glasses. Radiochemistry 2000, 42, 273-274. 
208. Hirst, J.P.; Claridge, J.B.; Rosseinsky, M.J.; Bishop, P. High temperature synthesis of a noncentrosymmetric site-ordered cobalt aluminophosphate related to the pollucite structure, The Royal Society of Chemistry. Chem. Commun. 2003, 6, 684-685. [CrossRef]

209. Orlova, A.I. Crystal Chemical View on Elaboration of Ecology Safe Materials for Immobilization of Alkaline elements of Radwaste. In III International Pyroprocessing Research Conference; NIIAR: Dimitrovgrad, Russia, 2010; pp. 27-28.

210. Loginova, E.E.; Orlova, A.I.; Mikhailov, D.A.; Troshin, A.N.; Borovikova, E.Y.; Samoilov, S.G.; Kazantsev, G.N.; Kazakova, A.Y.; Demarin, V.T. Phosphorus-Containing Compounds of Pollucite Structure and Radiochemical Problems. Radiochemistry 2011, 53, 593-603. [CrossRef]

211. Orlova, A.I.; Volgutov, V.Y.; Mikhailov, D.A.; Troshin, A.N.; Golovkina, L.S.; Skuratov, V.A.; Kirilkin, N.S.; Chuvil'diev, V.N.; Nokhrin, A.V.; Boldin, M.S.; et al. Mineral like compounds with NZP and Pollucite structures: synthesis of high density ceramic and radiation testing. In European Congress on Advanced Materials and Processes; EUROMAT 2011; FEMS: Montpellier, France, 2011.

212. Yanase, I.; Saito, Y.; Kobayashi, H. Synthesis and thermal expansion of (V, P, Nb)-replaced pollucite. Ceram. Int. 2012, 38, 811-815. [CrossRef]

213. Orlova, A.I.; Troshin, A.N.; Mikhailov, D.A.; Chuvil'deev, V.N.; Boldin, M.S.; Sakharov, N.V.; Nokhrin, A.V.; Skuratov, V.A.; Kirilkin, N.S. Phosphorus-Containing Cesium Compounds of Pollucite Structure. Preparation of High-Density Ceramic and Its Radiation Tests. Radiochemistry 2014, 56, 98-104. [CrossRef]

214. Klapshin, Y.P. Chemical and Phase Transformations during the Synthesis of $\mathrm{Cs}\left[\mathrm{MgR}_{0.5} \mathrm{P}_{1.5} \mathrm{O}_{6}\right](\mathrm{R}=\mathrm{B}, \mathrm{Al}, \mathrm{Fe})$ Complex Oxides from Metal Chlorides. Russ. J. Inorg. Chem. 2018, 63, 1156-1163. [CrossRef]

215. Klapshin, Y.P. Chemical and Phase Transformations during the Synthesis of $\mathrm{Cs}\left[\mathrm{MgR}_{0.5} \mathrm{P}_{1.5} \mathrm{O}_{6}\right](\mathrm{R}=\mathrm{B}, \mathrm{Al}, \mathrm{Fe})$ Complex Oxides from Metal Nitrates. Russ. J. Inorg. Chem. 2018, 63, 1381-1388. [CrossRef]

216. Townes, W.D.; Fang, J.H.; Perrotta, A.J. The Crystal Structure and Refinement of Ferromagnetic Barium Ferrite, $\mathrm{BaFe}_{12} \mathrm{O}_{19}$. Z. Kristallogr. 1967, 125, 437-449. [CrossRef]

217. Morgan, P.E.D.; Clarke, D.R.; Jantzen, C.M.; Harker, A.B. High Alumina Tailored Nuclear Waste Ceramics. J. Am. Ceram. Soc. 1981, 64, 249-258. [CrossRef]

218. Harker, A.B.; Jantzen, C.M.; Clarke, D.R.; Morgan, P.E.D. Tailored Ceramic Nuclear Waste Forms: Preparation and Characterization. In Science Basis for Nuclear Waste Management, III; Moore, J.G., Ed.; Plenum Press: New York, NY, USA, 1981; pp. 139-146.

219. Morgan, P.E.D.; Cirlin, E.H. The Magnetoplumbite Crystal Structure as a Radwaste Host. J. Am. Ceram. Soc. 1982, 65, C114-C115. [CrossRef]

220. Jantzen, C.M.; Clarke, D.R.; Morgan, P.E.D.; Harker, A.B. Leaching of Polyphase Nuclear Waste Ceramics: Microstructural and Phase Characterization. J. Am. Ceram. Soc. 1982, 65, 292-300. [CrossRef]

221. Bansal, N.P.; Zhu, D. Thermal properties of oxides with magnetoplumbite structure for advanced thermal barrier coatings. Surf. Coat. Technol. 2008, 202, 2698-2703. [CrossRef]

222. Men, D.; Patel, M.K.; Usov, I.O.; Pivin, J.C.; Porter, J.R.; Mecartney, M.L. Radiation Damage of $\operatorname{LaMgAl}_{11} \mathrm{O}_{19}$ and $\mathrm{CeMgAl}_{11} \mathrm{O}_{19}$ Magnetoplumbite. J. Am. Ceram. Soc. 2013, 96, 3325-3332.

223. Rakshit, S.K.; Parida, S.C.; Lilova, K.; Navrotsky, A. Thermodynamic studies of $\mathrm{CaLaFe}_{11} \mathrm{O}_{19}$ (s). J. Solid State Chem. 2013, 2, 68-74. [CrossRef]

224. Angle, J.P.; Nelson, A.T.; Men, D.; Mecartney, M.L. Thermal measurements and computational simulations of three-phase $\left(\mathrm{CeO}_{2}-\mathrm{MgAl}_{2} \mathrm{O}_{4}-\mathrm{CeMgAl}{ }_{11} \mathrm{O}_{19}\right)$ and four-phase (3Y-TZP- $\left.\mathrm{Al}_{2} \mathrm{O}_{3}-\mathrm{MgAl}_{2} \mathrm{O}_{4}-\mathrm{LaPO}_{4}\right)$ composites as surrogate inert matrix nuclear fuel. J. Nucl. Mater. 2014, 454, 69-76. [CrossRef]

225. Ewing, R.C.; Lutze, W.; Weber, W.J. Zircon: A host-phase for the disposal of weapons plutonium. J. Mater. Res. 1995, 10, 243-246. [CrossRef]

226. Shi, Y.; Huang, X.; Yan, D. Fabrication of Hot-Pressed Zircon Ceramics: Mechanical Properties and Microstructure. Ceram. Int. 1997, 23, 457-462. [CrossRef]

227. Meldrum, A.; Boatner, L.A.; Ewing, R.C. A comparison of radiation effects in crystalline $\mathrm{ABO}_{4}$-type phosphates and silicates. Mineral. Mag. 2000, 64, 185-194. [CrossRef]

228. Burakov, B.E.; Anderson, E.B.; Zamoryanskaya, M.V.; Yagovkina, M.A.; Strykanova, E.E.; Nikolaeva, E.V. Synthesis and Study of ${ }^{239} \mathrm{Pu}$-Doped Ceramics Based on Zircon, $(\mathrm{Zr}, \mathrm{Pu}) \mathrm{SiO}_{4}$, and Hafnon, $(\mathrm{Hf}, \mathrm{Pu}) \mathrm{SiO}_{4}$. In Material Research Society Symposium Proceedings Scientific Basis for Nuclear Waste Management XXIV; Materials Research Society: Warrendale, PA, USA, 2001; Volume 663, pp. 307-313. 
229. Hanchar, J.M.; Burakov, B.E.; Anderson, E.B.; Zamoryanskaya, M.V. Investigation of Single Crystal Zircon, $(\mathrm{Zr}, \mathrm{Pu}) \mathrm{SiO}_{4}$, Doped with ${ }^{238} \mathrm{Pu}$. In Scientific Basis for Nuclear Waste Management XXVI, Materials Research Society Symposium Proceedings; Finch, R.J., Bullen, D.B., Eds.; Materials Research Society: Warrendale, PA, USA, 2003; Volume 757, pp. 215-225.

230. Geisler-Wierwille, T.; Burakov, B.E.; Zirlin, V.; Nikolaeva, L.; Pöml, P. A Raman spectroscopic study of high-uranium zircon from the Chernobyl "Lava". Eur. J. Mineral. 2005, 17, 883-894. [CrossRef]

231. Burakov, B.E.; Domracheva, Y.V.; Zamoryanskaya, M.V.; Petrova, M.A.; Garbuzov, V.M.; Kitsay, A.A.; Zirlin, V.A. Development and synthesis of durable self-glowing crystals doped with plutonium. J. Nucl. Mater. 2009, 385, 134-136. [CrossRef]

232. Rendtorff, N.M.; Grasso, S.; Hu, C.; Suarez, G.; Aglietti, E.F.; Sakka, Y. Dense zircon $\left(\mathrm{ZrSiO}_{4}\right)$ ceramics by high energy ball milling and spark plasma sintering. Ceram. Int. 2012, 38, 1793-1799. [CrossRef]

233. IAEA. Radiation Protection and NORM Residue Management in the Zircon and Zirconia Industries; Safety Reports Series 51; IAEA: Vienna, Austria, 2007; 149p.

234. Pöml, P.; Burakov, B.; Geisler, T.; Walker, C.T.; Grange, M.L.; Nemchin, A.A.; Berndt, J.; Fonseca, R.O.C.; Bottomley, P.D.W.; Hasnaoui, R. Micro-analytical uranium isotope and chemical investigations of zircon crystals from the Chernobyl "lava" and their nuclear fuel inclusions. J. Nucl. Mater. 2013, 439, 51-56. [CrossRef]

235. Ojovan, M.I.; Burakov, B.E.; Lee, W.E. Radiation-induced microcrystal shape change as a mechanism of wasteform degradation. J. Nucl. Mater. 2018, 501, 162-171. [CrossRef]

236. Hayden, L.A.; Watson, E.B.; Wark, D.A. A thermobarometer for sphene (titanite). Contrib. Mineral. Petrol. 2008, 155, 529-540. [CrossRef]

237. Park, T.J.; Li, S.; Navrotsky, A. Thermochemistry of glass forming Y-substituted Sr-analogues of titanite (SrTiSiO 5 ). J. Mater. Res. 2009, 24, 3380-3386. [CrossRef]

238. Scanu, T.; Guglielmi, J.; Colomban, P. Ion exchange and hot corrosion of ceramic composites matrices: A vibrational and microstructural study. Solid State Ion. 1994, 70-71, 109-120. [CrossRef]

239. Weber, W.J. Radiation-induced Swelling and Amorphization in $\mathrm{Ca}_{2} \mathrm{Nd}_{8}\left(\mathrm{SiO}_{4}\right)_{6} \mathrm{O}_{2}$. Radiat. Eff. Defects Solids 1983, 77, 295-308. [CrossRef]

240. Fahey, J.A.; Weber, W.J.; Rotella, F.J. An X-ray and Neutron Powder Diffraction Study of the $\mathrm{Ca}_{2+x} \mathrm{Nd}_{8-\mathrm{x}}\left(\mathrm{SiO}_{4}\right)_{6} \mathrm{O}_{2-0.5 x}$ System. J. Solid State Chem. 1985, 60, 145-158. [CrossRef]

241. Weber, W.J. Alpha-decay-induced Amorphization in Complex Silicate Structures. J. Am. Ceram. Soc. 1993, 76, 1729-1738. [CrossRef]

242. Utsunomiya, S.; Yudintsev, S.; Wang, L.M.; Ewing, R.C. Ion-beam and Electron-beam Irradiation of Synthetic Britholite. J. Nucl. Mater. 2003, 322, 180-188. [CrossRef]

243. Leo'n-Reina, L.; Losilla, E.R.; Martı́nez-Lara, M.; Bruque, S.; Llobet, A.; Sheptyakov, D.V.; Aranda, M.A.G. Interstitial Oxygen in Oxygen-stoichiometric Apatites. J. Mater. Chem. 2005, 15, 2489-2498. [CrossRef]

244. Terra, O.; Dacheux, N.; Audubert, F.; Podor, R. Immobilization of tetravalent actinides in phosphate ceramics. J. Nucl. Mater. 2006, 352, 224-232. [CrossRef]

245. Malavasi, L.; Fisher, C.A.J.; Islam, M.S. Oxide-ion and proton conducting electrolyte materials for clean energy applications: Structural and mechanistic features. Chem. Soc. Rev. 2010, 39, 4370-4387. [CrossRef]

246. Knyazev, A.V.; Bulanov, E.N.; Korshunov, A.O.; Krasheninnikova, O.V. Synthesis and thermal expansion of some lanthanide-containing apatites. Inorg. Mater. 2013, 49, 1133-1137. [CrossRef]

247. Bulanov, E.N.; Knyazev, A.V. High-temperature in situ XRD investigations in apatites. Structural interpretation of thermal deformations. In Apatite: Synthesis, Structural Characterization and Biomedical Applications; Nova Science Publishers, Inc.: Hauppauge, NY, USA, 2014; Chapter 7; pp. 173-200.

248. Bulanov, E.N.; Wang, J.; Knyazev, A.V.; White, T.; Manyakina, M.; Baikie, T.; Lapshin, A.N.; Dong, Z. Structure and thermal expansion of calcium-thorium apatite, $\left[\mathrm{Ca}_{4}\right] \mathrm{F}\left[\mathrm{Ca}_{2} \mathrm{Th}_{4}\right] \mathrm{T}\left[\left(\mathrm{SiO}_{4}\right)_{6}\right] \mathrm{O}_{2}$. Inorg. Chem. 2015, 54, 11356-11361. [CrossRef]

249. Knyazev, A.V.; Bulanov, E.N.; Smirnova, N.N.; Korokin, V.Z.; Shushunov, A.N.; Blokhina, A.G.; Xu, Z. Thermodynamic and thermophysics properties of synthetic britholite $\mathrm{SrPr}_{4}\left(\mathrm{SiO}_{4}\right)_{3} \mathrm{O}$. J. Chem. Thermodyn. 2017, 108, 38-44. [CrossRef]

250. Cronstedt, A.F. Observation and Description of an Unknown Kind of Rock to be Named Zeolites. Kong Vetenskaps Acad. Handl. Stockh. 1756, 12, 120-123. (In Swedish)

251. Smith, J.V. Structural Classification of Zeolites. Mineral. Soc. Am. Spec. Pap. 1963, 1, 281. 
252. Breck, D.A. Zeolite Molecular Sieves: Structure, Chemistry and Use; Wiley-Interscience: New York, NY, USA, 1974.

253. Smith, J.V. Origin and Structure of Zeolites. In Zeolite Chemistry and Catalysis; A.C.S. Series; Rabo, J.A., Ed.; American Chemical Society: Washington, DC, USA, 1976; Volume 171, pp. 1-79.

254. Barrer, R.M. Hydrothermal Chemistry of Zeolites; Academic Press: New York, NY, USA, 1982.

255. Harjula, R.; Lehto, J. Effect of sodium and potassium ions on cesium absorption from nuclear power plant waste solutions on synthetic zeolites. Nucl. Chem. Waste Manag. 1986, 6, 133-137. [CrossRef]

256. Higgins, F.M.; de Leeuw, N.H.; Parker, S.C. Modelling the Effect of Water on Cation Exchange in Zeolite A. J. Mater. Chem. 2002, 12, 124-131.

257. Lima, E.; Ibarra, A.; Bosch, P.; Bulbulian, S. Vitrification of CsA and CsX zeolites. Stud. Surf. Sci. Catal. 2004, 154, 1907-1911.

258. Tsukada, T.; Takahashi, K. Absorption Characteristics of Fission Product Elements on Zeolite. Nucl. Technol. 2008, 162, 229-243. [CrossRef]

259. Kaminski, M.D.; Mertz, C.J.; Ferrandon, M.; Dietz, N.L.; Sandi, G. Physical properties of an alumino-silicate waste form for cesium and strontium. J. Nucl. Mater. 2009, 392, 510-518. [CrossRef]

260. Cappelletti, P.; Rapisardo, G.; De Gennaro, B.; Colella, A.; Langella, A.; Fabio, S.; Lee, D.; De Gennaro, M. Immobilization of $\mathrm{Cs}$ and $\mathrm{Sr}$ in aluminosilicate matrices derived from natural zeolites. J. Nucl. Mater. 2011, 414, 451-457. [CrossRef]

261. Gatta, G.D.; Merlini, M.; Lotti, P.; Lausi, A.; Rieder, M. Microporous and Mesoporous Materials Phase stability and thermo-elastic behavior of $\mathrm{CsAlSiO}_{4}(\mathrm{ABW})$ : A potential nuclear waste disposal material. Microporous Mesoporous Mater. 2012, 163, 147-152. [CrossRef]

262. Yamagishi, I.; Nagaishi, R.; Kato, C.; Morita, K.; Terada, A.; Kamiji, Y. Characterization and storage of radioactive zeolite waste. J. Nucl. Sci. Technol. 2014, 51, 1044-1053. [CrossRef]

263. Gallis, F.S.; Ermanoski, I.; Greathouse, J.A.; Chapman, K.W.; Nenoff, T.M. Iodine Gas Adsorption in Nanoporous Materials: A Combined Experiment-Modeling Study. Ind. Eng. Chem. Res. 2017, 56, 2331-2338. [CrossRef]

264. Lee, H.Y.; Kim, H.S.; Jeong, H.-K.; Park, M.; Chung, D.-Y.; Lee, E.-H.; Lim, W.T. Selective Removal of Radioactive Cesium from Nuclear Waste by Zeolites: On the Origin of Cesium Selectivity Revealed by Systematic Crystallographic Studies. J. Phys. Chem. C 2017, 121, 10594-10608. [CrossRef]

265. Papynov, E.K. Spark plasma sintering of ceramic and glass-ceramic matrices for cesium radionuclides immobilization. In Glas-Ceramics: Properties, ApplIcations and Technolology; Narag, K., Ed.; Nova Science Publisher, Inc.: New York, NY, USA, 2018; pp. 109-153.

266. Papynov, E.K.; Shichalin, O.O.; Mayorov, V.Y.; Kuryavyi, V.G.; Kaidalova, T.A.; Teplukhina, L.V.; Portnyagin, A.S.; Slobodyuk, A.B.; Belov, A.A.; Tananaev, I.G.; et al. SPS technique for ionizing radiation source fabrication based on dense cesium-containing core. J. Hazard. Mater. 2019, 369, 25-30. [CrossRef]

267. Strachan, D.M.; Schulz, W.W. Characterization of Pollucite as a Material for Long-Term Storage of Cesium-137. Am. Ceram. Soc. Bull. 1979, 58, 865-871.

268. Gallagher, S.A.; McCarthy, G.J. Preparation and X-ray Characterization of Pollucite $\left(\mathrm{CsAlSi}_{2} \mathrm{O}_{6}\right)$. Inorg. Nucl. Chem. 1981, 43, 1773-1777. [CrossRef]

269. Komameni, S.; White, W.B. Stability of Pollucite in Hydrothermal Fluids. Sci. Basis Nucl. Waste Manag. 1981, 3, 387-396.

270. Yanagisawa, K.; Nishioka, M.; Yamasaki, N. Immobilization of Cesium into Pollucite Structure by Hydrothermal Hot-Pressing. J. Nucl. Sci. Technol. 1987, 24, 51-60. [CrossRef]

271. Mielearski, M. Preparation of ${ }^{137}$ Cs Pollucite Source Core. Isotopenpraxis 1989, 25, 404-408. [CrossRef]

272. Mimura, H.; Shibata, M.; Akiba, K. Surface Alteration of Pollucite under Hydrothermal Conditions. J. Nucl. Sci. Technol. 1990, 27, 835-843. [CrossRef]

273. Anthony, R.G.; Phillip, C.V.; Dosch, R.G. Selective Adsorption and Ion Exchange of Metal Cations and Anions with Silico-Titanates and Layered Titanates. Waste Manag. 1993, 13, 503-512. [CrossRef]

274. Balmer, M.L.; Bunker, B.C. Inorganic Ion Exchange Evaluation and Design-Silicotitanate Ion Exchange Waste Conversion; PNL-10460; Pacific Northwest Laboratory: Richland, WA, USA, 1995.

275. Su, Y.; Balmer, M.L.; Bunker, B.C. Evaluation of Cesium Silicotitanates as an Alternate Waste Form. Mater. Res. Soc. Symp. Proc. 1996, 465, 457-464. [CrossRef] 
276. McCready, D.E.; Balmer, M.L.; Keefer, K.D. Experimental and Calculated X-ray Diffraction Data for Cesium Titanium Silicate, CsTiSi ${ }_{2} \mathrm{O}_{6,5}$ : A New Zeolite. Powder Diffr. 1997, 12, 40-46. [CrossRef]

277. Su, Y.; Balmer, M.L.; Wang, L.; Bunker, B.C.; Nyman, M.; Nenoff, T.; Navrotsky, A. Evaluation of Thermally Converted Silicotitanate Waste Forms. Mater. Res. Soc. Symp. Proc. 1999, 556, 77-84. [CrossRef]

278. Xu, H.; Navrotsky, A.; Nyman, M.D.; Nenoff, T.M. Thermochemistry of Microporous Silicotitanate Phases in the $\mathrm{Na}_{2} \mathrm{O}-\mathrm{Cs}_{2} \mathrm{O}-\mathrm{SiO}_{2}-\mathrm{TiO}_{2}-\mathrm{H}_{2} \mathrm{O}$ System. J. Mater. Res. 2000, 15, 815-823. [CrossRef]

279. Xu, H.; Navrotsky, A.; Balmer, M.L.; Su, Y.; Bitten, E.R. Energetics of Substituted Pollucites along the $\mathrm{CsAlSi}_{2} \mathrm{O}_{6}-\mathrm{CsTiSi}_{2} \mathrm{O}_{6,5}$ Join: A High-Temperature Calorimetric Strudy. J. Am. Ceram. Soc. 2001, 84, 555-560. [CrossRef]

280. Bubnova, R.S.; Stepanov, N.K.; Levin, A.A.; Filatov, S.K.; Paufler, P.; Meyer, D.C. Crystal structure and thermal behavior of boropollucite $\mathrm{CsBSi}_{2} \mathrm{O}_{6}$. Solid State Sci. 2004, 6, 629-637. [CrossRef]

281. Richerson, D.W.; Hummel, F.A. Synthesis and Thermal Expansion of Polycrystalline Cesium Minerals. J. Am. Ceram. Soc. 2006, 55, 269-273. [CrossRef]

282. Rehspringer, J.-L.; Balencie, J.; Vilminot, S.; Burger, D.; Boos, A.; Estournes, C. Confining caesium in expanded natural Perlite. J. Eur. Ceram. Soc. 2007, 27, 619-622. [CrossRef]

283. Garino, T.G.; Nenoff, T.M.; Park, T.J.; Navrotsky, A. The Crystallization of Ba-Substituted CsTiSi ${ }_{2} \mathrm{O}_{6.5}$ Pollucite using CsTiSi ${ }_{2} \mathrm{O}_{6.5}$ Seed Crystals. J. Am. Ceram. Soc. 2009, 92, 2144-2146. [CrossRef]

284. Park, T.-J.; Garino, T.J.; Nenoff, T.M.; Rademacher, D.; Navrotsky, A. The Effect of Vacancy and Ba-Substitution on the Stability of the $\mathrm{CsTiSi}_{2} \mathrm{O}_{6.5}$ Pollucite. J. Am. Ceram. Soc. 2011, 94, 3053-3059. [CrossRef]

285. He, P.; Jia, D. Low-temperature sintered pollucite ceramic from geopolymer precursor using synthetic metakaolin. J. Mater. Sci. 2013, 48, 1812-1818. [CrossRef]

286. Garino, T.J.; Rademacher, D.X.; Rodriguez, M.; Nenoff, T.M. The Synthesis of Ba and Fe Substituted CsAlSi ${ }_{2} \mathrm{O}_{6}$ Pollucites. J. Am. Ceram. Soc. 2013, 96, 2966-2972.

287. Jing, Z.; Hao, W.; He, X.; Fan, J.; Zhang, Y.; Miao, J.; Jin, F. A novel hydrothermal method to convert incineration ash into pollucite for the immobilization of a simulant radioactive cesium. J. Hazard. Mater. 2016, 306, 220-229. [CrossRef]

288. Fan, J.; Jing, Z.; Zhang, Y.; Miao, J.; Chen, Y.; Jin, F. Mild hydrothermal synthesis of pollucite from soil for immobilization of Cs in situ and its characterization. Chem. Eng. J. 2016, 304, 344-350. [CrossRef]

289. Vance, E.R.; Gregg, D.J.; Griffiths, G.J.; Gaugliardo, P.R.; Grant, C. Incorporation of Ba in $\mathrm{Al}$ and Fe pollucite. J. Nuc. Mater. 2016, 478, 256-260. [CrossRef]

290. Henderson, C.M.B.; Charnock, J.M.; Bell, J.M.; van der Laan, G.C.M.B. X-ray absorption study of 3d transition-metals and $\mathrm{Mg}$ in glasses and analogue crystalline materials in $\mathrm{AFe}^{3+} \mathrm{Si}_{2} \mathrm{O}_{6}$ and $\mathrm{A}_{2} \mathrm{X}^{2+} \mathrm{Si}_{5} \mathrm{O}_{12}$, where $\mathrm{A}=\mathrm{K}, \mathrm{Rb}$, or $\mathrm{Cs}$ and $\mathrm{X}=\mathrm{Mg}, \mathrm{Mn}, \mathrm{Fe}, \mathrm{Co}, \mathrm{Ni}, \mathrm{Cu}$, or Zn. J. Non-Cryst. Solids 2016, 451, $23-48$. [CrossRef]

291. Omerasevic, M.; Matovic, L.; Ruzic, J.; Golubovic, Z.; Jovanovic, U.; Mentus, S.; Dondur, V. Safe trapping of cesium into pollucite structure by hot-pressing method. J. Nuc. Mater. 2016, 474, 35-44. [CrossRef]

292. Hamada, S.; Kishimura, H.; Matsumoto, H.; Takahashi, K.; Aruga, A. Effect of shock compression on luminescence properties of $\mathrm{CsAlSi}_{2} \mathrm{O}_{6}: \mathrm{Eu}^{2+}$ for white-light-emitting diodes. Opt. Mater. 2016, 62, 192-198. [CrossRef]

293. Orlova, A.I.; Chuvildeev, V.N.; Mikhailov, D.A.; Boldin, M.S.; Belkin, O.A.; Nokhrin, A.V.; Sakharov, N.V.; Skuratov, V.A.; Kirilkin, S. Preparation of ceramic materials with mineral-like structures by mean of SPS technology for the purpose of radwaste consolidation and radiation and hydrolytic investigations. J. Nucl. Energy Sci. Power Gener. Technol. 2017, 6, 33.

294. Berry, L.G.; Mason, B. Mineralogy Concepts, Descriptions, Determinations; W.H. Freeman \& Co.: San Francisco, CA, USA, 1959.

295. Deer, W.A.; Howie, R.A.; Zussman, J. Rock-Forming Minerals, Vol IV; John Wiley \& Sons, Inc.: New York, NY, USA, 1963.

296. Klingenberg, R.; Felsche, J. Interstitial Cristobalite-type Compounds $\left.\left(\mathrm{Na}_{2} \mathrm{O}\right) \leq 0.33 \mathrm{Na}\left[\mathrm{AlSiO}_{4}\right]\right)$. J. Solid State Chem. 1986, 61, 40-46. [CrossRef]

297. Kim, J.G.; Lee, J.H.; Kim, I.T.; Kim, E.H. Fabrication of a Glass-Bonded Zeolite Waste Form for Waste LiCl Salt. J. Ind. Eng. Chem. 2007, 13, 292-298.

298. Brookins, D.G. Geochemical Aspects of Radioactive Waste Disposal; Springer: Berlin, Germany, 1984.

299. Fleet, M.E. Structures of Sodium Alumino-Germanate Sodalites. Acta Cryst. 1989, C45, 843-847. 
300. McFarlane, H.F.; Goff, K.M.; Felicione, F.S.; Dwight, C.C.; Barber, D.B. Hot Demonstrations of Nuclear-Waste Processing Technologies. JOM 1997, 49, 14-21. [CrossRef]

301. Deer, W.A.; Howie, R.A.; Zussman, J. Rock-Forming Minerals. Vol. 2A. Single-Chain Silicates; Geological Society: London, UK, 1997.

302. Nakazawa, T.; Kato, H.; Okada, K.; Ueta, S.; Mihara, M. Iodine Immobilization by Sodalite Waste Form. Mater. Res. Soc. Symp. Proc. 2001, 663, 51-57. [CrossRef]

303. Olson, A.L.; Soelberg, N.R.; Marshal, D.W.; Anderson, G.L. Fluidized Bed Steam Reforming of INEEL SBW Using THOR Mineralizing Technology; INEEL/EXT-04-02564; Idaho National Laboratory: Idaho Falls, ID, USA, 2004.

304. Deer, W.A.; Howie, R.A.; Wise, W.S.; Zussman, J. Rock-Forming Minerals, Vol. 4B, Framework Silicates: Silica Minerals, Feldspathoids and the Zeolites; The Geological Society: London, UK, 2004.

305. Mattigod, S.V.; McGrail, B.P.; McCready, D.E.; Wang, L.; Parker, K.E.; Young, J.S. Synthesis and Structure of Perrhenate Sodalite. J. Microporous Mesopourous Mater. 2006, 91, 139-144. [CrossRef]

306. Angelis, G.D.; Capone, M.; Mannielo, A.; Mariani, M.; Maceratu, E.; Conti, C. Different methods for conditioning Chlorite Salt waste from Pyroprocesses. In Book of Abstracts "III International Pyroprocessing Research Conference; NIIAR: Dimitrovgrad, Russia, 2010; p. 48.

307. Simpson, M.F.; Allensworth, J.R.; Phongikaroon, S.; Williams, A.N.; Dunzik-Gourgar, M.L.; Ferguson, C. Immobilization of Salt from Zone Freezing Process in Zeolite-A. In III International Pyroprocessing Research Conference; NIIAR: Dimitrovgrad, Russia, 2010; pp. 30-31.

308. Akimkhan, A.M. Structural and Ion-Exchange Properties of Natural Zeolite. Ion Exch. Technol. 2012, 10, 261-283.

309. Tendeloo, L.V.; Blochouse, B.; Dom, D.; Vancluysen, J.; Snellings, R.; Martens, J.A.; Kirschhock, C.E.A.; Maes, A.; Breynaert, E. Cation Exchange Properties of Zeolites in Hyper Alkaline Aqueous Media. Environ. Sci. Technol. 2015, 49, 1729-1737. [CrossRef]

310. Olszewska, W.; Miśkiewicz, A.; Zakrzewska-Kołtuniewicz, G.; Lankof, L.; Pająk, L. Multibarrier system preventing migration of radionuclides from radioactive waste repository. Nukleonika 2015, 60, 557-563. [CrossRef]

311. Kim, H.S.; Park, J.S.; Lim, W.T. Site Competition of $\mathrm{Ca}^{2+}$ and $\mathrm{Cs}^{+}$Ions in the Framework of Zeolite Y $(\mathrm{Si} / \mathrm{Al}=1.56)$ and Their Crystallographic Studies. J. Mineral. Soc. Korea 2018, 31, 235-248. [CrossRef]

312. Ovhal1, S.; Butler, I.S.; Xu, S. The Potential of Zeolites to Block the Uptake of Radioactive Strontium-90 in Organisms. Contemp. Chem. 2018, 1, 1-13.

313. Dyer, A.; Hriljac, J.; Evans, N.; Stokes, I.; Rand, P.; Kellet, S.; Harjula, R.; Moller, T.; Maher, Z.; Heatlie-Branson, R.; et al. The use of columns of the zeolite clinoptilolite in the remediation of aqueous nuclear waste streams. J. Radioanal. Nucl. Chem. 2018, 318, 2473-2491. [CrossRef]

314. Grundy, H.D.; Hassan, I. The crystal structure of a carbonate-rich cancrinite. Can. Mineral. 1982, 20, $239-251$.

315. Zhao, H.; Deno, Y.; Harsh, J.B.; Flury, M.; Boyle, J.S. Alteration of Kaolinite to Cancrinite and Sodalite by simulated Hanford tank waste and its inpact on cesium retention. Clay Mater. 2004, 52, 1-13.

316. Mon, J.; Deng, Y.; Flury, M.; Harsh, J.B. Cesium incorporation and diffusion in cancrinite, sodalite, zeolite, and allophone. Microporous Microporous Mater. 2005, 86, 277-286. [CrossRef]

317. Hassan, I.; Antao, S.M.; Parise, J.B. Cancrinite: Crystal structure, phase transitions, and dehydration behavior with temperature. Am. Mineral. 2006, 91, 1117-1124. [CrossRef]

318. Deng, Y.; Flury, M.; Harsh, J.B.; Felmy, A.R.; Qafoku, O. Cancrinite and sodalite formation in the presence of cesium, potassium, magnesium, calcium and strontium in Hanford tank waste stimulant. Appl. Geochem. 2006, 21, 2049-2063. [CrossRef]

319. Dickson, J.O.; Harsh, J.B.; Flury, M.; Lukens, W.W.; Pierce, E.M. Immobilization and Exchange of Perrhenate in Sodalite and Cancrinite. Microporous Mesoporous Mater. 2015, 214, 115-120. [CrossRef]

320. Zheng, Z.; Anthony, R.G.; Miller, J.E. Modeling Multicomponent Ion Exchange Equilibrium Utilizing Hydrous Crystalline Silicotitanates by a Multiple Interactive Ion Exchange Site Model. Ind. Eng. Chem. Res. 1997, 36, 2427-2434. [CrossRef]

321. Miller, J.E.; Brown, N.E. Development and Properties of Crystalline Silicotitanate (CST) Ion Exchangers for Radioactive Waste Applications; SAND97-0771; Sandia National Laboratories: Albuquerque, NM, USA, 1997.

322. Andrews, M.K.; Harbour, J. Glass Formulation Requirements for Hanford Coupled Operations Using Crystalline Silicotitanates (CST); WSRC-RP-97-0265; Westinghouse Savannah River Company, Savannah River Site: Aike, SC, USA, 1997. 
323. Yu, B.; Chen, J.; Song, C. Crystalline Silicotitanate: A New Type of Ion Exchange for Cs Removal from Liquid Waste. J. Mater. Sci. Technol. 2002, 18, 206-210.

324. Tripathi, A.; Medvedev, D.G.; Nyman, M.; Clearfield, A. Selectivity for Cs and Sr in Nb-Substituted Titanosilicate with Sitinakite Topology. J. Solid State Chem. 2003, 175, 72-83. [CrossRef]

325. Keppler, H. Ion Exchange Reactions Between Dehydroxylated Micas and Salt Melts and the Crystal Chemistry of the Interlayer Cation in Micas. Am. Minerial. 1990, 75, 529-538.

326. Fleet, M.E. Rock-Forming Minerals: Sheet Silicates: Micas, V. 3A; The Geological Society: Bath, Englad, 2003.

327. Jantzen, C.M.; Williams, M.R.; Bibler, N.E.; Crawford, C.L.; Jurgensen, A.R. Fluidized Bed Steam Reformed (FBSR) Mineral Waste Forms: Application to Cs-137/Sr-90 Wastes for the Global Nuclear Energy Partnership (GNEP); U.S. DOE Report WSRC-MS; Savannah River National Laboratory: Jackson, MS, USA, 2008.

328. Jantzen, C.M.; Williams, M.R. Fluidized Bed Steam Reforming (FBSR) Mineralization for High Organic and Nitrate Waste Streams for the Global Nuclear Energy Partnership (GNEP); Waste Management 08, Paper \#8314 (2008); WM Symposia: Phoenix, AZ, USA, 2008; p. 8314.

329. Neeway, J.J.; Qafoku, N.P.; Peterson, R.A.; Brown, C.F. Characterization and Leaching Tests of the Fluidized Bed Steam Reforming (FBSR) Waste Form for LAW Immobilizatio; Waste Management 2013, Paper 13400; WM Symposia: Phoenix, AZ, USA, 2013.

330. Kumar, A.; Singh, Y.P.; Pradhan, G.; Dhawan, N. Utilization of Mica for Potassium Recovery. In Proceedings. Mater. Today 2018, 5, 17030-17034.

331. Boatner, L.A.; Sales, B.C. Monazite. In Radiation Waste Forms for the Future; Lutze, W., Ewing, R.C., Eds.; North-Holland Press: Amsterdam, The Netherlands, 1988; pp. 495-564.

332. Ewing, R.C.; Weber, W.J.; Lutze, W. Crystalline Ceramics: Waste Forms for the Disposal of Weapons Plutonium. In Disposal of Ex-weapons Plutonium as Waste; NATIO ASI Series; Merz, E.R., Walter, C.E., Eds.; Kluwer Academic Publishers: Dordrecht, The Netherlands, 1996; pp. 65-83.

333. Merz, E.R.; Walter, C.E. Disposal of Ex-weapons Plutonium as Waste, NATIO ASI Series; Kluwer Academic Publishers: Dordrecht, The Netherlands, 1996; pp. 65-83.

334. Van Emden, B.; Thornber, M.R.; Graham, J.; Lincoln, F.J. The incorporation of actinides in monazite and xenotime from placer deposits in Western Australia. Can. Mineral. 1997, 35, 95-104.

335. Chang, L.L.Y.; Howie, R.A.; Zussman, J. Rock-Forming Minerals, V.5B Non-Silicates. In Sulphates, Carbonates, Phosphates, Halides, 2nd ed.; The Geological Society: London, UK, 1998; Volume 383, ICBN 978-1897799901.

336. Genet, M.; Dacheux, N.; Thomas, A.C.; Chassigneux, B.; Pichot, E.; Brandel, V. Thorium phosphatediphosphate as a ceramic for the immobilization of tetravalent uranium, neptunium and plutonium. Waste Manag. 1999, 99, 38.

337. Clavier, N.; Dacheux, N.; Podor, R.; Le Coustumer, P. Study of Actinides Incorporation in Thorium Phosphate-Diphosphate/Monazite Based Ceramics. Mater. Res. Soc. Symp. Proc. 2004, 802, DD3.6.1-DD3.6.6. [CrossRef]

338. Burakov, B.E.; Yagovkina, M.A.; Garbuzov, V.M.; Kitsay, A.A.; Zirlin, V.A. SelfIrradiation of Monazite Ceramics: Contrasting Behavior of $\mathrm{PuPO} 4$ and $(\mathrm{La}, \mathrm{Pu}) \mathrm{PO}_{4}$ Doped with Pu-238. In Scientific Basis for Nuclear Waste Management XXVIII; Hanchar, J.M., Stroes-Gascoyne, S., Browning, L., Eds.; Materials Research Society Symposium Proceedings: San Francisco, CA, USA, 2004; Volume 824, pp. 219-224.

339. Montel, J.M.; Glorieux, B.; Seydoux-Guilaume, A.M.; Wirth, R. Synthesis and Sintering of a Monazitebrabantite Solid Solution Ceramic for Nuclear Waste Storage. J. Phys. Chem. Solids 2006, 67, 2489-2500. [CrossRef]

340. Zhang, Y.J.; Vance, E.R. Plutonium in Monazite and Brabanite: Diffuse Reflectance Spectroscopy Study. J. Nucl. Mater. 2008, 375, 311-314. [CrossRef]

341. Glorieux, B.; Montel, J.M.; Matecki, M. Synthesis and Sintering of a Monazite-brabantite Solid Solution Ceramics Using Metaphosphate. J. Eur. Ceram. Soc. 2009, 29, 1679-1686. [CrossRef]

342. Brandt, F.; Neumeier, S.; Schuppik, T.; Arinicheva, Y.; Bukaemskiy, A.; Modolo, G.; Bosbach, D. Conditioning of minor actinides in lanthanum monazite ceramics: A surrogate with Europium. Prog. Nucl. Energy 2014, 72, 140-143. [CrossRef]

343. Arinicheva, Y.; Bukaemskiy, A.; Neumeier, S.; Modolo, G.; Bosbach, D. Studies on thermal and mechanical properties of monazite-type ceramics for the conditioning of minor actinides. Prog. Nucl. Energy 2014, 72, 144-148. [CrossRef] 
344. Mezentseva, L.P.; Kruchinina, I.Y.; Osipov, A.V.; Kuchaeva, S.K.; Ugolkov, V.L.; Popova, V.F.; Pugachev, K.E. Nanopowders of Orthophosphate $\mathrm{LaPO}_{4}-\mathrm{YPO}_{4}-\mathrm{H}_{2} \mathrm{O}$ System and Ceramics Based on Them. Glass Phys. Chem. 2014, 40, 356-361. [CrossRef]

345. Ma, J.; Teng, Y.; Huang, Y.; Wu, L.; Zhang, K.; Zhao, X. Effects of sintering process, $\mathrm{pH}$ and temperature on chemical durability of $\mathrm{Ce}_{0.5} \mathrm{Pr}_{0.5} \mathrm{PO}_{4}$ ceramics. J. Nucl. Mater. 2015, 465, 550-555. [CrossRef]

346. Zhao, X.; Teng, Y.; Yang, H.; Huang, Y.; Ma, J. Comparison of microstructure and chemical durability of $\mathrm{Ce}_{0.9} \mathrm{Gd}_{0.1} \mathrm{PO}_{4}$ ceramics prepared by hot-press and pressureless sintering. Ceram. Int. 2015, 41, 11062-11068. [CrossRef]

347. Teng, Y.; Zeng, P.; Huang, Y.; Wu, L.; Wang, X. Hot-pressing of monazite $\mathrm{Ce}_{0.5} \operatorname{Pr}_{0.5} \mathrm{PO}_{4}$ ceramic and its chemical durability. J. Nucl. Mater. 2015, 465, 482-487. [CrossRef]

348. Zhao, X.; Teng, Y.; Wu, L.; Huang, Y.; Ma, J.; Wang, G. Chemical durability and leaching mechanism of $\mathrm{Ce}_{0.5} \mathrm{Eu}_{0.5} \mathrm{PO}_{4}$ ceramics: Effects of temperature and $\mathrm{pH}$ values. J. Nucl. Mater. 2015, 466, 187-193. [CrossRef]

349. Teng, Y.; Wang, X.; Huang, Y.; Wu, L.; Zeng, P. Hot-pressure sintering, microstructure and chemical durability of $\mathrm{Ce}_{0.5} \mathrm{Eu}_{0.5} \mathrm{PO}_{4}$ monazite ceramics. Ceram. Int. 2015, 41, 10057-10062. [CrossRef]

350. Meng, C.; Ding, X.; Zhao, J.; Ren, C.; Fu, H.; Yang, H. Phase evolution and microstructural studies of $\mathrm{Gd}_{1-\mathrm{x}} \mathrm{Yb}_{\mathrm{x}} \mathrm{PO}_{4}(0 \leq \mathrm{x} \leq 1)$ ceramics for radioactive waste storage. J. Eur. Ceram. Soc. 2016, 36, 773-779. [CrossRef]

351. Potanina, E.; Golovkina, L.; Orlova, A.; Nokhrin, A.; Boldin, M.; Sakharov, N. Lanthanide (Nd, Gd) compounds with garnet and monazite structures. Powders synthesis by "wet" chemistry to sintering ceramics by Spark Plasma Sintering. J. Nucl. Mater. 2016, 473, 93-98. [CrossRef]

352. Ji, Y.; Kowalski, P.M.; Neumeier, S.; Deissmann, G.; Kulriya, P.K.; Gale, J.D. Atomistic modeling and experimental studies of radiation damage in monazite-type $\mathrm{LaPO}_{4}$ ceramics. Nucl. Instrum. Methods Phys. Res. 2017, 393, 54-58. [CrossRef]

353. Babelot, C.; Bukaemskiy, A.; Neumeier, S.; Modolo, G.; Bosbach, D. Crystallization processes, compressibility, sinterability and mechanical properties of La-monazite-type ceramics. J. Eur. Ceram. Soc. 2017, 37, 1681-1688. [CrossRef]

354. Guo, L.; Yan, Z.; Li, Z.; Yu, J.; Wang, Q.; Li, M.; Ye, F. GdPO 4 as a novel candidate for thermal barrier coating applications at elevated temperatures. Surf. Coat. Technol. 2018, 349, 400-406. [CrossRef]

355. Arinicheva, Y.; Gausse, C.; Neumeier, S.; Brandt, F.; Rozov, K.; Szenknect, S.; Dacheux, N.; Bosbach, D.; Deissmann, G. Influence of temperature on the dissolution kinetics of synthetic $\mathrm{LaPO}_{4}$-monazite in acidic media between 50 and $130^{\circ} \mathrm{C}$. J. Nucl. Mater. 2018, 509, 488-495. [CrossRef]

356. Arinicheva, Y.; Clavier, N.; Neumeier, S.; Podor, R.; Bukaemskiy, A.; Klinkenberg, M.; Roth, G.; Dacheux, N.; Bosbach, D. Effect of powder morphology on sintering kinetics, microstructure and mechanical properties of monazite ceramics. J. Eur. Ceram. Soc. 2018, 38, 227-234. [CrossRef]

357. Zhao, X.; Li, Y.; Teng, Y.; Wu, L.; Bi, P.; Wang, L.; Wang, S. The structure, sintering process, and chemical durability of $\mathrm{Ce}_{0.5} \mathrm{Gd}_{0.5} \mathrm{PO}_{4}$ ceramics. Ceram. Int. 2018, 44, 19718-19724. [CrossRef]

358. Zhao, X.; Li, Y.; Teng, Y.; Wu, L.; Bi, P.; Yang, X.; Wan, L. The effect of Ce content on structure and stability of $\mathrm{Gd}_{1-\mathrm{x}} \mathrm{Ce}_{\mathrm{x}} \mathrm{PO}_{4}$ : Theory and experiment. J. Eur. Ceram. Soc. 2019, 39, 1555-1563. [CrossRef]

359. Milligan, W.O.; Mullica, D.F.; Beall, G.W.; Boatner, L.A. Structural investigation of $\mathrm{YPO}_{4}, \mathrm{ScPO}_{4}$, and LuPO 4 . Inorg. Chim. Acta 1982, 60, 39-43. [CrossRef]

360. Boatner, L. Synthesis, Structure, and Properties of Monazite, Pretulite, and Xenotime. Rev. Mineral. Geochem. 2002, 48, 87-121. [CrossRef]

361. Hetherington, C.J.; Hasrlov, D.E.; Budzyn, B. Experimental metasomatism of monazite and xenotime: Mineral stability, REE mobility and fluid composition. Miner. Petrol. 2010, 99, 165-184. [CrossRef]

362. Ji, Y.; Beridze, G.; Bosbach, D.; Kowalski, P.M. Heat capacities of xenotime-type ceramics: An accurate ab initio prediction. J. Nucl. Mater. 2017, 494, 172-181. [CrossRef]

363. Kondrat'eva, O.N.; Nikiforova, G.E.; Tyurin, A.V.; Ryumin, M.A.; Gurevich, V.M.; Kritskaya, A.P.; Gavrichev, K.S. Calorimetric study of ytterbium orthovanadate $\mathrm{YbVO}_{4}$ polycrystalline ceramics. Ceram. Int. 2018, 44, 18103-18107. [CrossRef]

364. Weber, W.J.; Turcotte, R.P.; Bunnell, L.R.; Roberts, F.P.; Westsik, J.H., Jr. Radiation Effects in Vitreous and Devitrified Simulated Waste Glass (Contains Apatite). In Proceedings of the International Symposium on Ceramics in Nuclear Waste Management, Cincinnati, OH, USA, 28 April-3 May 1979; pp. 294-299. 
365. Weber, W.J. Radiation Damage in Rare-earth Silicate with the Apatite Structure. J. Am. Ceram. Soc. 1982, 65, 544-548. [CrossRef]

366. Bros, R.; Carpens, J.; Sere, V.; Beltritti, A. Occurrence of Plutonium and Fissiogenic REE in Hydrothermal Apatites from the Nuclear Reactor 16 at Oklo (Gabon). Radiochim. Acta 1996, 74, 277-282. [CrossRef]

367. Weber, W.J.; Ewing, R.C.; Meldrum, A. The Kinetics of Alpha-decay-induced Amorphization in Zircon and Apatite Containing Weapons-grade Plutonium or Other Actinides. J. Nucl. Mater. 1997, 250, 147-155. [CrossRef]

368. Audubert, F.J.; Lacout, J.L.; Tetard, F. Elaboration of an Iodine-Bearing Apatite Iodine Diffusion into a $\mathrm{Pb}_{3}\left(\mathrm{VO}_{4}\right)_{2}$ Matrix. Solid State Ion. 1997, 95, 113-119. [CrossRef]

369. Boyer, L.; Carpena, J.; Lacout, J.L. Synthesis of Phosphate-Silicate Apatites at Atmospheric Pressure. Solid State Ion. 1997, 95, 121-129. [CrossRef]

370. Carpena, J.; Donazzon, B.; Ceraulo, E.; Prene, S. Composite Apatitic Cement as a Material to Retain Cesium and Iodine. Comptes Rendus de L Academie Des Sciences Serie II Fascicule C-Chimie 2001, 4, 301-308.

371. Park, H.S.; Kim, I.T.; Kim, H.Y.; Lee, K.S.; Ryu, S.K.; Kim, J.H. Application of Apatite Waste Form for the Treatment of Water-soluble Wastes Containing Radioactive Elements. Part 1: Investigation on the Possibility. J. Ind. Eng. Chem. 2002, 8, 318-327.

372. Elliott, J.C.; Wilson, R.M.; Dowker, S.E.P. Apatite Structures. Adv. X-ray Anal. 2002, 45, 172-181.

373. Kim, J.Y.; Dong, Z.L.; White, T.J. Model Apatite Systems for the Stabilization of Toxic Metals: II, Ccation and Metalloid Substitutions in Chlorapatites. J. Am. Ceram. Soc. 2005, 88, 1253-1260. [CrossRef]

374. Carpena, J.; Lacout, J.L. Calcium Phosphate Nuclear Materials: Apatitic Ceramics for Separated Wastes. Actual. Chim. 2005, 66-71.

375. Jothinathan, E.; Vammeesel, K.; Vleugels, J. Apatite type lanthanum silicate and composite anode half cells. Solid State Ion. 2011, 192, 419-423. [CrossRef]

376. Knyazev, A.V.; Chernorukov, N.G.; Bulanov, E.N. Apatite-structured compounds: Synthesis and hightemperature investigation. Mater. Chem. Phys. 2012, 132, 773-781. [CrossRef]

377. Wang, J. Incorporation of iodine into apatite structure: a crystal chemistry approach using Artificial Neural Network. Front. Earth Sci. 2015, 3, 1-11. [CrossRef]

378. Kirkland, C.L.; Yakymchuk, C.; Szilas, K.; Evans, N.; Hollis, J.; McDonald, B.; Gardiner, N.J. Apatite: A U-Pb thermochronometer or geochronomete. Lithos 2018, 318-319, 143-157. [CrossRef]

379. Hong, H.Y.-P. Crystal structures and crystal chemistry in the system $\mathrm{Na}_{1+\mathrm{x}} \mathrm{Zr}_{2} \mathrm{SixP}_{3}-\mathrm{xO}_{12}$. Mater. Res. Bull. 1976, 11, 173-182. [CrossRef]

380. Goodenough, J.B.; Hong, H.Y.-P.; Kafalas, J.A. Fast Na+-ion transport in skeleton structures. Mater. Res. Bull. 1976, 11, 203-220. [CrossRef]

381. Boilot, J.P.; Salanié, J.P.; Desplanches, G.; Le Potier, D. Phase transformation in Na1+xSixZr2P3-xO12 compounds. Mater. Res. Bull. 1979, 14, 1469-1477. [CrossRef]

382. de la Rochère, M.; d'Yvoire, F.; Collin, G.; Comès, R.; Boilot, J.P. NASICON type materials- $\mathrm{Na}_{3} \mathrm{M}_{2}\left(\mathrm{PO}_{4}\right)_{3}(\mathrm{M}$ $=\mathrm{Sc}, \mathrm{Cr}, \mathrm{Fe}): \mathrm{Na}^{+}-\mathrm{Na}^{+}$correlations and phase transitions. Solid State Ion. 1983, 9-10 Pt 2, 825-828. [CrossRef]

383. Manthiram, A.; Goodenough, J.B. Lithium Insertion into Fe2(MO4)3 Frameworks: Comparison of $\mathrm{M}=\mathrm{W}$ with $\mathrm{M}=$ Mo. J. Solid State Chem. 1987, 71, 349-360. [CrossRef]

384. Roy, R.; Vance, E.R.; Alamo, J. [NZP], a new radiophase for ceramic nuclear waste forms. Mater. Res. Bull. 1982, 17, 585-589. [CrossRef]

385. Alamo, R.; Roy, R. Crystal chemistry of the $\mathrm{NaZr}_{2}\left(\mathrm{PO}_{4}\right)_{3}, \mathrm{NZP}$ or CTP, structure family. J. Mater. Sci. 1986, 21, 444-450. [CrossRef]

386. Scheetz, B.E.; Roy, R. Novel Waste Forms. In Radioactive Waste Forms for the Future; Lutze, W., Ewing, R.C., Eds.; North-Holland: Amsterdam, The Netherlands, 1988; pp. 596-599.

387. Orlova, A.I.; Zyryanov, V.N.; Kotel'nikov, A.R.; Demarin, V.T.; Rakitina, E.V. Ceramic phosphate matrices for high level waste. Behaviour in hydrothermal conditions. Radiokhimiya 1993, 35, 120-126.

388. Orlova, A.I.; Volkov, Y.F.; Melkaya, R.F.; Masterova, L.Y.; Kulikov, I.A.; Alferov, V.A. Synthesis and Radiation Stability of NZP Phosphates Containg F-elements. Radiochemistry 1994, 36, 322-325.

389. Scheetz, B.E.; Agrawal, D.K.; Breval, E.; Roy, R. Sodium Zirconium-phosphate (NZP) as a Host Structure for Nuclear Waste Immobilization-A Review. Waste Manag. 1994, 14, 489-505. [CrossRef] 
390. Hawkins, H.T.; Scheetz, B.E.; Guthrie, G.D., Jr. Preparation of Monophasic [NZP] Radiophases: Potential Host Matrices for the Immobilization of Reprocessed Commercial High-Level Wastes. In Scientific Basis for Nuclear Waste Management. XX; Gray, W.J., Triay, I.R., Eds.; Material Research Society: Pittsburgh, PA, USA, 1997; pp. 387-394.

391. Zyryanov, V.N.; Vance, E.R. Comparison of Sodium Zirconium Phosphate-Structured HLW forms and Synroc for High-Level Nuclear Waste Immobilization. In Scientific Basis for Nuclear Waste Management. XX; Gray, W.J., Triay, I.R., Eds.; Material Research Society: Pittsburgh, PA, USA, 1997; pp. 409-416.

392. Miyajima, Y.; Miyoshi, T.; Tamaki, J.; Matsuoka, M.; Yamamoto, Y.; Masquelier, C.; Tabuchi, M.; Saito, Y.; Kageyama, $\mathrm{H}$. Solubility range and ionic conductivity of large trivalent ion doped $\mathrm{Na}_{1+\mathrm{x}} \mathrm{M}_{\mathrm{x}} \mathrm{Zr}_{2-\mathrm{x}} \mathrm{P}_{3} \mathrm{O}_{12}$ (M: In, Yb, Er, Y, Dy, Tb, Gd) solid electrolytes. Solid State Ion. 1999, 124, 201-211. [CrossRef]

393. Orlova, A.I.; Charlamova, A.A.; Volkov, Y.F. Investigation of Plutonium, Americium and Curium Phosphates as a Basis for Inclusion into Kosnarite-type Ceramic Waste Worms. In Review of Excess Weapons Plutonium Disposition, LLNL Contract Work in Russia, Proceedings of the 3rd Annual Meeting for Coordination and Review of LLNL Contract Work, St. Petersburg, Russia, 14-18 January 2002; Lawrence Livermore National Laboratory: Livermore, CA, USA, 2002; pp. 407-418.

394. Orlova, A.I.; Orlova, V.A.; Buchirin, A.V.; Beskrovnyi, A.I.; Kurazhkovskaya, V.S. Cesium and Its Analogs, Rubidium and Potassium, in Rhombohedral $\left[\mathrm{NaZr}_{2}\left(\mathrm{PO}_{4}\right)_{3}\right.$ Type] and Cubic (Langbeinite Type) Phosphates: 1. Crystal-Chemical Studies. Radiochemistry 2005, 47, 225-234. [CrossRef]

395. Bykov, D.M.; Orlova, A.I.; Tomilin, S.V.; Lizin, A.A.; Lukinykh, A.N. Americium and Plutonium on Trigonal Phosphates (NZP Type) $\mathrm{AM}_{1 / 3} \mathrm{Zr}_{2}\left(\mathrm{PO}_{4}\right)_{3}$ and $\mathrm{Pu}_{1 / 4} \mathrm{Zr}_{2}\left(\mathrm{PO}_{4}\right)_{3}$. Radiochemistry 2006, 48, 234-239. [CrossRef]

396. Bykov, D.M.; Konings, R.J.M.; Orlova, A.I. High Temperature Investigations of the rare earth NZP phosphates $\mathrm{R}_{1 / 3} \mathrm{Zr}_{2}\left(\mathrm{PO}_{4}\right)_{3}(\mathrm{R}=\mathrm{La}, \mathrm{Nd}, \mathrm{Eu}, \mathrm{Lu})$ by drop calorimetry. J. Alloy. Compd. 2007, 439, 376-379. [CrossRef]

397. Nalk, A.H.; Deb, S.B.; Chalke, A.B.; Saxena, M.K.; Ramakumar, K.L.; Venugopal, V.; Dharwadkar, S.R. Microwave-assisted low temperature synthesis of sodium zirconium phosphate (NZP) and the leachability of some selected fission products incorporated in its structure-A case study of leachability of cesium. J. Chem. Sci. 2010, 122, 71-82.

398. Orlova, A.I.; Lizin, A.A.; Tomilin, S.V.; Lukinykh, A.N.; Kanunov, A.E.; Chuvil'deev, V.N.; Boldin, M.S.; Sakharov, N.V.; Nokhrin, A.V. Actinide Phosphates with $\mathrm{NaZr}_{2}\left(\mathrm{PO}_{4}\right)_{3}$ Structure. High-Speed Production of Dense Ceramics. In Book of Abstracts: The 49-th Conference on Hot Laboratories and Remote Handling "HOTLAB 2012"; CEA: Marcoule, France, 2012.

399. Orlova, A.I.; Volgutov, V.Y.; Mikhailov, D.A.; Bykov, D.M.; Skuratov, V.A.; Chuvil'deev, V.N.; Nokhrin, A.V.; Boldin, M.S.; Sakharov, N.V. Phosphate $\mathrm{Ca}_{1 / 4} \mathrm{Sr}_{1 / 4} \mathrm{Zr}_{2}\left(\mathrm{PO}_{4}\right)_{3}$ of the $\mathrm{NaZr}_{2}\left(\mathrm{PO}_{4}\right)_{3}$ type: Synthesis of a dense ceramic material and its radiation testing. J. Nucl. Mater. 2014, 441, 232-239. [CrossRef]

400. Bohre, A.; Shrivastava, O.P.; Awasthi, K. Crystal Chemistry of Immobilization of Tetravalent Ce and Se in Ceramic Matrix of Sodium Zirconium Phosphate. Phys. Chem. Res. 2014, 2, 21-29.

401. Pet'kov, V.; Asabina, E.; Loshkarev, V.; Sukhanov, M. Systematic investigation of the strontium zirconium phosphate ceramic form for nuclear waste immobilization. J. Nucl. Mater. 2016, 471, 122-128. [CrossRef]

402. Pet'kov, V.I.; Dmitrienko, A.S.; Sukhanov, M.V.; Koval'skii, A.M.; Borovikova, E.Y. Synthesis, phase formation, and thermal expansion of sulfate phosphates with the $\mathrm{NaZr}_{2}\left(\mathrm{PO}_{4}\right)_{3}$ structure. Russ. J. Inorg. Chem. 2016, 61, 623-629. [CrossRef]

403. Glukhova, I.O.; Asabina, E.A.; Pet'kov, V.I.; Borovikova, E.Y.; Koval'skii, A.M. Phase Formation, Structure, and Thermal Expansion of Phosphates $\mathrm{M}_{0.5(1+\mathrm{x})} \mathrm{Fe}_{\mathrm{x}} \mathrm{Ti}_{2-\mathrm{x}}\left(\mathrm{PO}_{4}\right)_{3}(\mathrm{M}=\mathrm{Mn}, \mathrm{Zn})$. Russ. J. Inorg. Chem. 2016, 61, 681-687. [CrossRef]

404. Liu, T.; Wang, B.; Gu, X.; Wang, L.; Ling, M.; Liu, G.; Wang, D.; Zhang, S. All-climate sodium ion batteries based on the NASICON electrode materials. Nano Energy 2016, 30, 756-761. [CrossRef]

405. Kim, Y.; Kim, H.; Park, S.; Seo, I.; Kim, Y. Na ion-conducting ceramic as solid electrolyte for rechargeable seawater batteries. Electrochim. Acta 2016, 191, 1-7. [CrossRef]

406. Wang, J.; Zhang, Z.J. Luminescence properties and energy transfer studies of color tunable $\mathrm{Tb}^{3+}$-doped $\mathrm{RE}_{1 / 3} \mathrm{Zr}_{2}\left(\mathrm{PO}_{4}\right)_{3}(\mathrm{RE}=\mathrm{Y}, \mathrm{La}, \mathrm{Gd}$ and Lu$)$. J. Alloys Compd. 2016, 685, 841-847. [CrossRef]

407. Ribero, D.; Seymour, K.C.; Kriven, W.M.; White, M.A. Synthesis of $\mathrm{NaTi}_{2}\left(\mathrm{PO}_{4}\right)_{3}$ by the inorganic-organic steric entrapment method and its thermal expansion behavior. J. Am. Ceram. Soc. 2016, 99, 3586-3593. [CrossRef] 
408. Ananthanarayanan, A.; Ambashta, R.D.; Sudarsan, V.; Ajithkumar, T.; Sen, D.; Mazumder, S.; Wattal, P.K. Structure and short time degradation studies of sodium zirconium phosphate ceramics loaded with simulated fast breeder (FBR) waste. J. Nucl. Mater. 2017, 487, 5-12. [CrossRef]

409. Kanunov, A.; Glorieux, B.; Orlova, A.; Borovikova, E.; Zavedeeva, G. Synthesis, structure and luminescence properties of phosphates $\mathrm{A}_{1-3 x} \mathrm{Eu}_{x} \mathrm{Zr}_{2}\left(\mathrm{PO}_{4}\right)_{3}$ (A-alkali metal). Bull. Mater. Sci. 2017, 40, 7-16. [CrossRef]

410. Orlova, A. Next Generation Ceramic Materials for Consolidation of radioactive alpha-wastes using the Innovative Technology Spark Plasma Sintering for their preparation. In Book of Abstracts: 3rd World Congress on Materials Science, Engineering, Oil, Gas and Petrochemistry; StatNano: Dunbai, UAE, 2018.

411. Kanunov, A.E.; Orlova, A.I. Phosphors Based on Phosphates of $\mathrm{NaZr}_{2}\left(\mathrm{PO}_{4}\right)_{3}$ and Langbeinite Structural Families. Rev. J. Chem. 2018, 8, 1-33. [CrossRef]

412. Hallopeau, L.; Bregiroux, D.; Rousse, G.; Portehault, D.; Stevens, P.; Toussaint, G.; Laberty-Robert, C. Microwave-assisted reactive sintering and lithium ion conductivity of $\mathrm{Li}_{1.3} \mathrm{Al}_{0.3} \mathrm{Ti}_{1.7}\left(\mathrm{PO}_{4}\right)_{3}$ solid electrolyte. J. Power Sources 2018, 378, 48-52. [CrossRef]

413. Wang, H.; Okubo, K.; Inada, M.; Hasegawa, G.; Enomoto, N.; Hayashi, K. Low temperature-densified NASICON-based ceramics promoted by $\mathrm{Na}_{2} \mathrm{O}-\mathrm{Nb}_{2} \mathrm{O}_{5}-\mathrm{P}_{2} \mathrm{O}_{5}$ glass additive and spark plasma sintering. Solid State Ion. 2018, 322, 54-60. [CrossRef]

414. Savinkh, D.O.; Khainakov, S.A.; Orlova, A.I.; Garcia-Granda, S. New Phosphate-Sulfates with NZP Structure. Russ. J. Inorg. Chem. 2018, 63, 714-724. [CrossRef]

415. Savinkh, D.O.; Khainakov, S.A.; Orlova, A.I.; Garcia-Granda, S. Preparation and Thermal Expansion of Calcium Iron Zirconium Phosphates with the $\mathrm{NaZr}_{2}\left(\mathrm{PO}_{4}\right)_{3}$ Structure. Inorg. Mater. 2018, 54, 591-595. [CrossRef]

416. Orlova, A.; Khainakov, S.; Alexandrov, A.; Garcia-Granda, S.; Savinykh, D. Crystallographic studies of $\mathrm{NaZr}_{2}\left(\mathrm{PO}_{4}\right)_{3}$ phosphates at high temperatures. In Book of Abstracts: 31-st European Crystallographic Meeting "ECM31"; European Crystallographic Association: Oviedo, Spain, 2018.

417. Savinkh, D.O.; Khainakov, S.A.; Boldin, M.S.; Orlova, A.I.; Aleksandrov, A.A.; Lantsev, E.A.; Sakharov, N.V.; Murashov, A.A.; Garcia-Granda, S.; Nokhrin, A.V.; et al. Preparation of NZP-Type $\mathrm{Ca}_{0.75+0.5 \mathrm{x}} \mathrm{Zr}_{1.5} \mathrm{Fe}_{0.5}\left(\mathrm{PO}_{4}\right)_{3-\mathrm{x}}\left(\mathrm{SiO}_{4}\right)_{\mathrm{x}}$ Powders and Ceramic, Thermal Expansion Behavior. Inorg. Mater. 2018, 54, 1267-1273. [CrossRef]

418. Orlova, A.I.; Loginova, E.E.; Logacheva, A.A.; Demarin, V.T.; Shmidt, O.V.; Nikolaev, A.Y. A Crystal-Chemical Approach in the Development of Phosphate Materials as Environmentally Safe Chemical Forms of Utilization of Spent Cs-Containing Ferrocyanide Sorbents. Radiochemistry 2010, 52, 462-468. [CrossRef]

419. Lizin, A.A.; Tomilin, S.V.; Gnevashov, O.E.; Lukinykh, A.N.; Orlova, A.I. Orthophosphates of Langbeinite Structure for Immobilization of Alkali Metal Cations of Salt Wastes from Pyrochemical Processes. Radiochemistry 2012, 54, 542-548. [CrossRef]

420. Martynov, K.V.; Nekrasov, A.N.; Kotel'nikov, A.R.; Tananaev, I.G. Synthesis and study of the chemical stability and strength of zirconium phosphates with the structure of langbeinite with imitators of high-level radioactive waste (HLRW). Glass Phys. Chem. 2017, 43, 75-82. [CrossRef]

421. Mold, P.; Bull, R.K.; Durrani, S.A. Constancy of ${ }^{244} \mathrm{Pu}$ distribution in chondritic whitlockite. Nuclear Tracks 1981, 5, 27-31. [CrossRef]

422. Nakamura, S.; Otsuka, R.; Aoki, H.; Akao, M.; Miura, N.; Yamamoto, T. Thermal expansion of hydroxyapatite$\beta$-tricalcium phosphate ceramics. Thermochim. Acta 1990, 165, 57-72. [CrossRef]

423. Belik, A.A.; Morozov, V.A.; Grechkin, S.V.; Khasanov, S.S.; Lazoryak, B.I. Crystal Structures of Double Vanadates, $\mathrm{Ca} 9 \mathrm{R}\left(\mathrm{VO}_{4}\right)_{7}$. III. R = Nd, Sm, Gd, or Ce. Crystallogr. Rep. 2000, 45, 798-803.

424. Orlova, A.I.; Orlova, M.P.; Solov'eva, E.N.; Loginova, E.E.; Demarin, V.T.; Kazantsev, G.N.; Samojlov, S.G.; Stefanovsky, S.V. Lanthanides in Phosphates with the structure of whitlockite mineral (analog of $\left.\beta-\mathrm{Ca}_{3}\left(\mathrm{PO}_{4}\right)_{2}\right)$. Radiochemistry 2006, 48, 561-567. [CrossRef]

425. Orlova, M.; Glorieux, B.; Orlova, A.; Montel, J.M.; Kazantsev, G.; Samoilov, S. Phosphates with structure of mineral whitlockite (beta- $\mathrm{Ca}_{3}\left(\mathrm{PO}_{4}\right)_{3}$. In Book of Abstracts: Engineering Conf. International ECI "Alternative Materials for Radioactive Waste Stabilization and Nuclear Materials Containment”; ECI: Brooklyn, NY, USA, 2007. 
426. Orlova, A.I.; Orlova, M.P.; Loginova, E.E.; Lizin, A.A.; Tomilin, S.V.; Lukinykh, A.N.; Khainakov, S.A.; Garcia-Granda, S.; Demarin, V.T.; Oleneva, T.A.; et al. Thorium, Plutonium, Lanthanides and Some 1- and 2-Valent Elements in the New Orthophosphates with the Structure of Mineral Whitlockite. Chemistry, Structure, Stability. In Abstracts Booklet "Plutoniun Future- "The Science", Proceedings of the Topical Conference on Plutonium and Actinides, Dijon, France, 7-11 July 2008; Elsevier: Amsterdam, Netherlands, 2008; pp. 313-314.

427. Orlova, A.I.; Khainakov, S.A.; Loginova, E.E.; Oleneva, T.A.; Garcia Granda, S.; Kurazhkovskaya, V.S. Calcium Thorium Phosphate (whitlockite type Mineral). Synthesis and Structure Refinement. Crystallogr. Rep. 2009, 54, 591-597. [CrossRef]

428. Benhamou, R.A.; Bessiere, A.; Wallez, G.; Viana, B.; Elaatmani, M.; Daoud, M.; Zegzouti, A. New insight in the structure-luminescence relationship of Ca9Eu(PO4)7. J. Solid State Chem. 2009, 182, 2319-2325. [CrossRef]

429. Orlova, A.I.; Orlova, M.P.; Loginova, E.E.; Khainakov, S.; Garcia-Granda, S.; Lizin, A.A.; Tomilin, S.V.; Lukinikh, A.N.; Kurazshkovskay, V.S. Nature "experience" and experimental data on immobilization of actinides into calcium phosphate with whitelochite mineral structure. In Book of Abstracts: 6th Russian Conference on Radiochemistry "Radiochemistry-2009"; Lomonosov Moscow State University: Moscow, Russia, 2009; p. 294.

430. Orlova, A.I.; Malanina, N.V.; Chuvil'deev, V.N.; Boldin, M.S.; Sakharov, N.V.; Nokhrin, A.V. Praseodymium and neodymium phosphates $\mathrm{Ca}_{9} \mathrm{Ln}\left(\mathrm{PO}_{4}\right)_{7}$ of whitlockite structure. Preparation of a ceramic with a high relative density. Radiochemistry 2014, 56, 380-384. [CrossRef]

431. Adcock, C.T.; Tschauner, O.; Hausrath, E.M.; Udry, A.; Luo, S.N.; Cai, Y.; Ren, M.; Lanzirotti, A.; Newville, M.; Kunz, M.; et al. Shock-transformation of whitlockite to merrillite and the implications for meteoritic phosphate. Nat. Commun. 2017, 8, 14667. [CrossRef]

432. Carrasco, I.; Piccinelli, F.; Bettinelli, M. Optical Spectroscopy of $\mathrm{Ca}_{9} \mathrm{~Tb}_{1-\mathrm{x}} \mathrm{Eu}_{\mathrm{x}}\left(\mathrm{PO}_{4}\right)_{7}(\mathrm{x}=0,0.1,1)$ : Weak Donor Energy Migration in the Whitlockite Structure. J. Phys. Chem. C 2017, 121, 16943-16950. [CrossRef]

433. Bénard, P.; Brandel, V.; Dacheux, N.; Jaulmes, S.; Launay, S.; Lindecker, C.; Genet, M.; Louër, D.; Quarton, M. $\mathrm{Th}_{4}\left(\mathrm{PO}_{4}\right)_{4} \mathrm{P}_{2} \mathrm{O}_{7}$, a New Thorium Phosphate: Synthesis, Characterization, and Structure Determination. Chem. Mater. 1996, 8, 181-188. [CrossRef]

434. Dacheux, N.; Podor, R.; Chassigneux, B.; Brandel, V.; Genet, M. Actinides Iimmobilization in New Matrices Bbased on Solid Solutions: $\mathrm{Th}_{4-\mathrm{x}} \mathrm{M}_{\mathrm{x}}{ }^{\mathrm{IV}}\left(\mathrm{PO}_{4}\right)\left({ }_{4}\right) \mathrm{P}_{2} \mathrm{O}_{7},(\mathrm{M}-\mathrm{IV}=\mathrm{U}-238, \mathrm{Pu}-239)$. J. Alloy. Compd. 1998, 271, 236-239. [CrossRef]

435. Dacheux, N.; Podor, R.; Brandel, V.; Genet, M. Investigations of systems $\mathrm{ThO}_{2}-\mathrm{MO}_{2}-\mathrm{P}_{2} \mathrm{O}_{5}(\mathrm{M}=\mathrm{U}, \mathrm{Ce}$, $\mathrm{Zr}, \mathrm{Pu}$ ). Solid Solutions of Thorium-Uranium(IV) and ThoriumPlutonium(IV) Phosphate-diphosphates. J. Nucl. Mater. 1998, 252, 179-186. [CrossRef]

436. Pichot, E.; Dacheux, N.; Brandel, V.; Genet, M. Investigation of Cs-137(+), Sr-85(2+) and Am-241(3+) Ion Exchange on Thorium Phosphate Hydrogenphosphate and their Immobilization in the Thorium Phosphate Diphosphate. New J. Chem. 2000, 24, 1017-1023. [CrossRef]

437. Clavier, N.; Dacheux, N.; Martinez, P.; Du Fou de Kerdaniel, E.; Aranda, L.; Podor, R. Sintering of $\beta$-Thorium-Uranium(IV) Phosphate-Diphosphate Solid Solutions from Low-Temperature Precursors. Chem. Mater. 2004, 16, 3357-3366. [CrossRef]

438. Clavier, N.; Dacheux, N.; Podor, R. Synthesis, characterization, sintering, and leaching of $\beta$-TUPD/monazite radwaste matrices. Inorg. Chem. 2006, 45, 22. [CrossRef]

439. Clavier, N.; Du Fou de Kerdaniel, E.; Dacheux, N.; Le Coustumer, P.; Drot, R.; Ravaux, J.; Simoni, E. Behavior of thorium-uranium (IV) phosphate-diphosphate sintered samples during leaching tests. Part II. Saturation processes. J. Nucl. Mater. 2006, 349, 304-316. [CrossRef]

440. Morozov, V.A.; Mironov, A.V.; Lazoryak, B.I.; Khaikina, E.G.; Basovich, O.M.; Rossell, M.D.; Van Tendeloo, G. $\mathrm{Ag}_{1 / 8} \mathrm{Pr}_{5 / 8} \mathrm{MoO}_{4}$ : An incommensurately modulated scheelite-type structure. J. Solid State Chem. 2006, 179, 1183-1191. [CrossRef]

441. Maček Kržmanc, M.; Logar, M.; Budič, B.; Suvorov, D. Dielectric and Microstructural Study of the $\mathrm{SrWO}_{4}$, $\mathrm{BaWO}_{4}$, and $\mathrm{CaWO}_{4}$ Scheelite Ceramics. J. Am. Ceram. Soc. 2011, 94, 2464-2472. [CrossRef]

442. Cheng, J.; He, J. Electrical properties of scheelite structure ceramic electrolytes for solid oxide fuel cells. Mater. Lett. 2017, 209, 525-527. [CrossRef]

443. Zhang, B.; Zhao, Q.; Zhao, C.; Chang, A. Comparison of structure and electrical properties of vacuum-sintered and conventional-sintered $\mathrm{Ca}_{1-\mathrm{x}} \mathrm{Y}_{\mathrm{x}} \mathrm{CeNbWO}_{8}$ NTC ceramics. J. Alloys Compd. 2017, 698, 1-6. [CrossRef] 
444. Xiao, M.; Sun, H.; Zhou, Z.; Zhang, P. Bond ionicity, lattice energy, bond energy, and microwave dielectric properties of $\mathrm{Ca}_{1-\mathrm{x}} \mathrm{Sr}_{\mathrm{x}} \mathrm{WO}_{4}$ ceramics. Ceram. Int. 2018, 44, 20686-20691. [CrossRef]

445. Potanina, E.A.; Orlova, A.I.; Nokhrin, A.V.; Boldin, M.S.; Sakharov, N.V.; Belkin, O.A.; Chuvil'deev, V.N.; Tokarev, M.G.; Shotin, S.V.; Zelenov, A.Y. Characterization of $\mathrm{Na}_{x}(\mathrm{Ca} / \mathrm{Sr})_{1-2 x} \mathrm{Nd}_{x} \mathrm{WO}_{4}$ complex tungstates fine-grained ceramics obtained by Spark Plasma Sintering. Ceram. Int. 2018, 44, 4033-4044. [CrossRef]

446. Potanina, E.A.; Orlova, A.I.; Mikhailov, D.A.; Nokhrin, A.V.; Chuvil'deev, V.N.; Boldin, M.S.; Sakharov, N.V.; Lantcev, E.A.; Tokarev, M.G.; Murashov, A.A. Spark Plasma Sintering of fine-grained $\mathrm{SrWO}_{4}$ and $\left.\mathrm{NaNd}_{(\mathrm{WO}}\right)_{2}$ tungstates ceramics with the scheelite structure for nuclear waste immobilization. J. Alloys Compd. 2019, 774, 182-190. [CrossRef]

447. Pang, L.-X.; Zhou, D.; Yue, Z.-X. Temperature independent low firing $\left[\mathrm{Ca}_{0.25}\left(\mathrm{Nd}_{1-\mathrm{x}} \mathrm{Bi}_{\mathrm{x}}\right)_{0.5}\right] \mathrm{MoO}_{4}(0.2 \leq \mathrm{x} \leq 0.8)$ microwave dielectric ceramics. J. Alloys Compd. 2019, 781, 385-388. [CrossRef]

448. Hanusa, J. Raman scattering and ifra-red spectra of tungstates $\mathrm{KLn}\left(\mathrm{WO}_{4}\right)_{2}$-family (Ln: La-Lu). J. Mol. Struct. 1984, 114, 471-474. [CrossRef]

449. Pages, M.; Freundlich, W. Phases of scheelite structure in the neptunium molybdate and sodium or litium molybdate systems. J. Inorg. Nucl. Chem. 1972, 34, 2797-2801. [CrossRef]

450. Lee, M.R.; Mahe, P. Molybdates et tungstates d'uranium IV et de sodium. C. R. Acad. Sci. Paris. 1974, 279, 1137-1170.

451. Tabuteau, A.; Pages, M. Identification and crystal chemistry of double molybdates of alkalimetals (K, Rb, Cs) and transuranium elements (Np, Pu, Am). J. Inorg. Nucl. Chem. 1980, 42, 401-403. [CrossRef]

452. Tabuteau, A.; Pages, M.; Freundlich, W. Sur les phases de structure sheelite dans les systems molybdate deplutonium-molybdate de litium du sodium. Mater. Res. Bull. 1972, 7, 691-697. [CrossRef]

453. Müller-Buschbaum, H.; Gallinat, S. Synthese und Röntgenstrukturanalyse von $\mathrm{KCuGd}_{2} \mathrm{Mo}_{4} \mathrm{O}_{16}$ und $\mathrm{CuTb}_{2} \mathrm{Mo}_{4} \mathrm{O}_{16}$. Z. Naturforsch. 1995, 50, 1794-1798. [CrossRef]

454. Basovich, M.; Khaikina, E.G.; Vasil'ev, E.V.; Frolov, A.M. Phase formation in the $\mathrm{Li}_{2} \mathrm{MoO}_{4}-$ $\mathrm{Rb}_{2} \mathrm{MoO}_{4}-\mathrm{Ln}_{2}\left(\mathrm{MoO}_{4}\right)_{3}$ systems and the poperties of $\mathrm{LiRbLn}_{2}\left(\mathrm{MoO}_{4}\right)_{4}$. Zh. Neorg. Khim. 1995, 40, 2047-251.

455. Basovich, O.M.; Khaikina, E.G.; Solodovnikov, S.F.; Tsyrenova, G.D. Phase formation in the systems $\mathrm{Li}_{2} \mathrm{MoO}_{4}-\mathrm{K}_{2} \mathrm{MoO}_{4}-\mathrm{Ln}_{2}\left(\mathrm{MoO}_{4}\right)_{3}(\mathrm{Ln}=\mathrm{La}, \mathrm{Nd}, \mathrm{Dy}, \mathrm{Er})$ and properties of triple molybdates $\mathrm{LiKLn}_{2}\left(\mathrm{MoO}_{4}\right)_{4}$. J. Solid State Chem. 2005, 178, 1580-1588. [CrossRef]

456. Szillat, H.; Müller-Buschbaum, H. Synthese und Kristallstructur von $\mathrm{KCuHoMo}_{4} \mathrm{O}_{16}$. Z. Nat. 1994, 49, 350-354.

457. Wang, Y.; Wu, W.; Fu, X.; Liu, M.; Cao, J.; Shao, C.; Chen, S. Metastable scheelite $\mathrm{CdWO}_{4}: \mathrm{Eu}^{3+}$ nanophosphors: Solvothermal synthesis, phase transitions and their polymorph-dependent luminescence properties. Dyes Pigment. 2017, 147, 283-290. [CrossRef]

458. Donald, I.W. Waste Immobilisation in Glass and Ceramic Based Hosts; Wiley: Chichester, UK, 2010; 507p.

459. Kinoshita, H. Development of ceramic matrices for high level radioactive waste. In Handbook of Advanced Radioactive Waste Conditioning Technologies; Ojovan, M., Ed.; Woodhead: Cambridge, UK, 2011; Chapter 10; p. 293.

460. Ojovan, M.I.; Lee, W.E.; Kalmykov, S.N. An Introduction to Nuclear Waste Immobilisation, 3rd ed.; Elsevier: Amsterdam, The Netherlands, 2019; p. 497.

461. Zhang, Y.; Wei, T.; Zhang, Z.; Kong, L.; Dayal, P.; Gregg, D.J. Uranium brannerite with Tb(III)/Dy(III) ions: Phase formation, structures, and crystallizations in glass. J. Am. Ceram. Soc. 2019, 1-11. [CrossRef]

(C) 2019 by the authors. Licensee MDPI, Basel, Switzerland. This article is an open access article distributed under the terms and conditions of the Creative Commons Attribution (CC BY) license (http://creativecommons.org/licenses/by/4.0/). 